\title{
Final Report - Assessment of Potential \\ Phosphate Ion-Cementitious Materials \\ Interactions
}

Manuscript Completed: November 2006

Date Published:

Prepared by:

D. J. Naus

C. H. Mattus

L. R. Dole

Oak Ridge National Laboratory

Managed by UT-Battelle, LLC

P.O. Box 2008

Oak Ridge, TN 37831-6283

H. L. Graves, III, NRC Project Manager

Prepared for the

U.S. Nuclear Regulatory Commission

Office of Nuclear Regulatory Research

Under Interagency Agreement No. 1886-N600-2N

NRC FIN No. N6002 
This report was prepared as an account of work sponsored by an agency of the United States Government. Neither the United States government nor any agency thereof, nor any of their employees, makes any warranty, express or implied, or assumes any legal liability or responsibility for the accuracy, completeness, or usefulness of any information, apparatus, product, or process disclosed, or represents that its use would not infringe privately owned rights. 


\begin{abstract}
The objectives of this limited study were to: (1) review the potential for degradation of cementitious materials due to exposure to high concentrations of phosphate ions; (2) provide an improved understanding of any significant factors that may lead to a requirement to establish exposure limits for concrete structures exposed to soils or ground waters containing high levels of phosphate ions;

(3) recommend, as appropriate, whether a limitation on phosphate ion concentration in soils or ground water is required to avoid degradation of concrete structures; and (4) provide a "primer" on factors that can affect the durability of concrete materials and structures in nuclear power plants.

An assessment of the potential effects of phosphate ions on cementitious materials was made through a review of the literature, contacts with concrete research personnel, and conduct of a "bench-scale" laboratory investigation. Results of these activities indicate that: no harmful interactions occur between phosphates and cementitious materials unless phosphates are present in the form of phosphoric acid; phosphates have been incorporated into concrete as set retarders, and phosphate cements have been used for infrastructure repair; no standards or guidelines exist pertaining to applications of reinforced concrete structures in high-phosphate environments; interactions of phosphate ions and cementitious materials has not been a concern of the research community; and laboratory results indicate similar performance of specimens cured in phosphate solutions and those cured in a calcium hydroxide solution after exposure periods of up to eighteen months. Relative to the "primer," a separate NUREG report has been prepared that provides a review of pertinent factors that can affect the durability of nuclear power plant reinforced concrete structures.
\end{abstract}


FOREWORD 


\section{CONTENTS}

\section{Page}

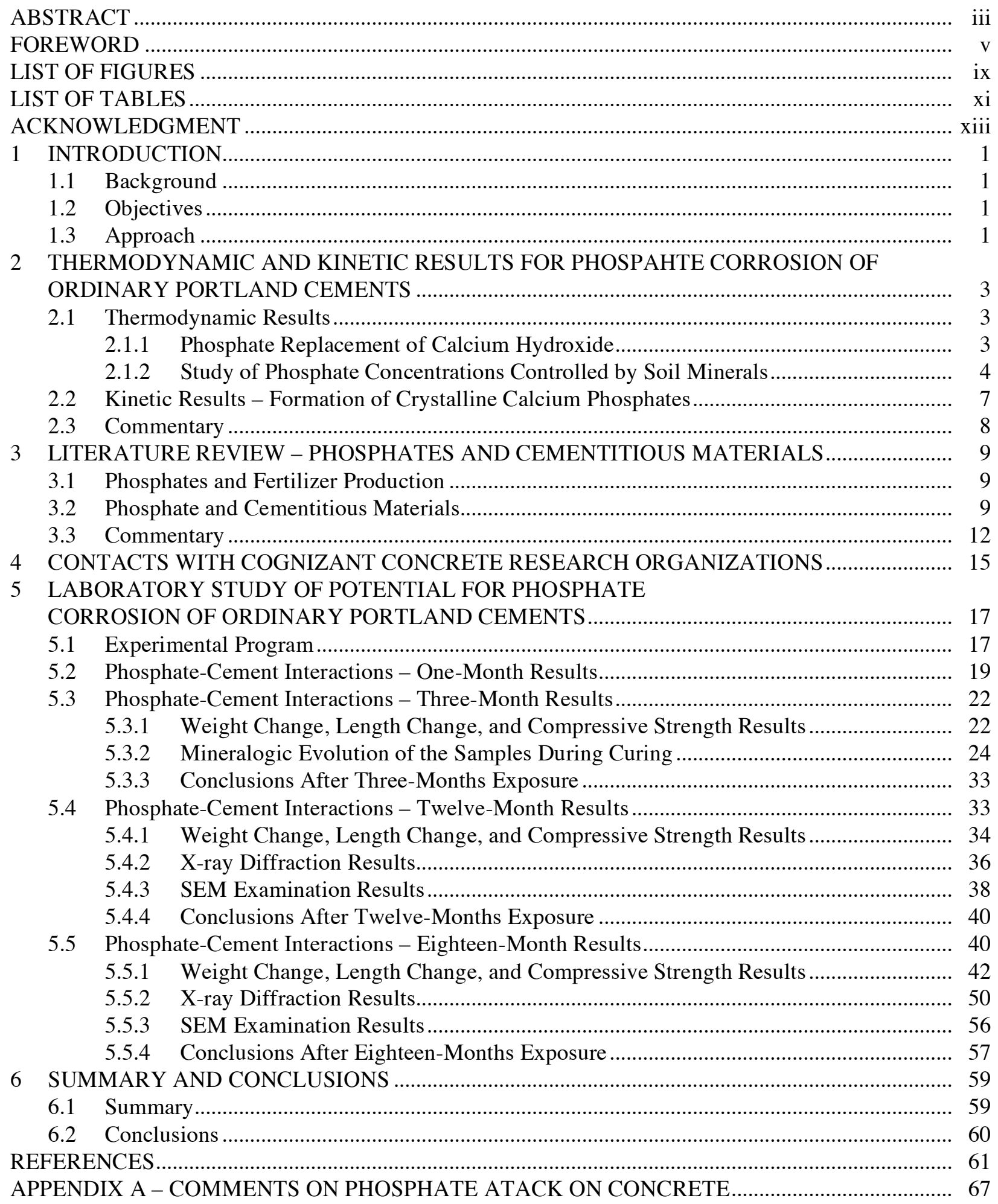




\section{LIST OF FIGURES}

Figure

Page

2.1 Phases in OPC that form under increasing exposure to phosphate............................................. 4

2.2 At equilibrium, sodium rich systems saturate the phosphate aqueous system to

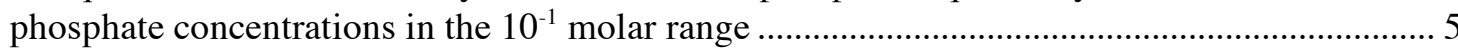

2.3 At equilibrium, magnesium rich systems saturate the phosphate aqueous system to phosphate concentrations in the $10^{-3}$ molar range ................................................................... 5

2.4 At equilibrium, calcium rich systems saturate the phosphate aqueous system to phosphate concentrations in the $10^{-5}$ molar range

Calcium hydroxyapatite forms in $\mathrm{Na}^{*} \mathrm{Mg} * \mathrm{Ca}$ systems in presence of $\mathrm{CO}_{2}$ from air or ground water. 6

Prismatic and cube test specimens

Length change test setup.......

Specimen weight determination

Representation of compressive strength test of cube test specimen

5.5 Exposure testing in saturated brines in which PVC corner braces are used to suspend cubes and prisms above the excess solids.

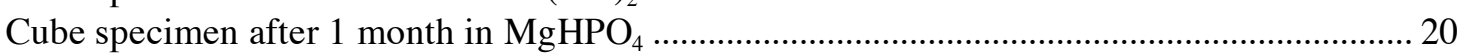

Unconfined compressive strength after one- and three-month exposure

of test specimens in $\mathrm{Ca}(\mathrm{OH})_{2}$

5.10 Unconfined compressive strength after one- and three-month exposure of test specimens in $\mathrm{Na}_{2} \mathrm{HPO}_{4}$

5.11 Unconfined compressive strength after one- and three-month exposure of test specimens in $\mathrm{MgHPO}_{4}$. 


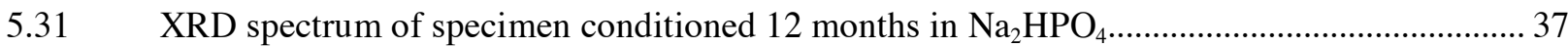

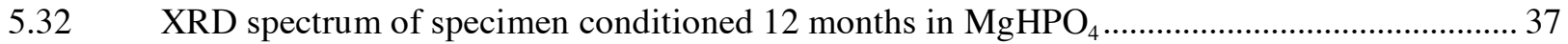

5.33 SEM result showing cement paste - 12 months conditioning in $\mathrm{Na}_{2} \mathrm{HPO}_{4}$ solution ................ 38

5.34 SEM result showing $\mathrm{C}_{3} \mathrm{~S}$ surrounded by dense layer of C-S-H -12 months conditioning in $\mathrm{Na}_{2} \mathrm{HPO}_{4}$ solution.

5.35 SEM result showing C-S-H and sulfoaluminates - 12 months conditioning in $\mathrm{Na}_{2} \mathrm{HPO}_{4}$ solution

5.36 SEM result showing Ettringite in cement paste - 12 months conditioning in $\mathrm{MgHPO}_{4}$ solution

5.37 SEM result showing calcium sulfoaluminates -12 months conditioning in $\mathrm{MgHPO}_{4}$ solution. 39

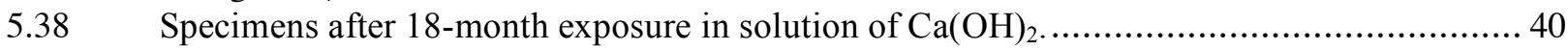

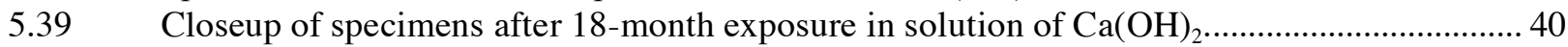

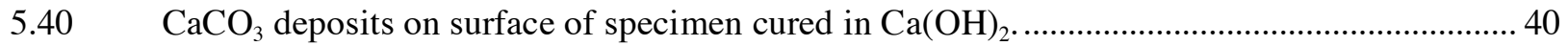

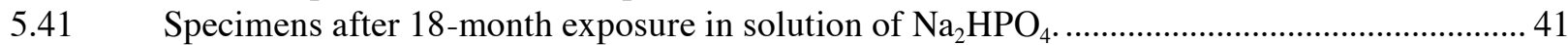

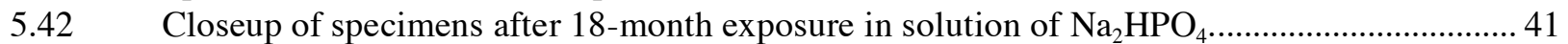

5.42 Carbonate crystal deposits on surface of specimen cured in $\mathrm{Na}_{2} \mathrm{HPO}_{4}$. ................................. 41

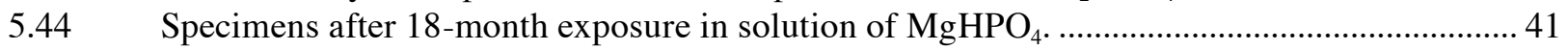

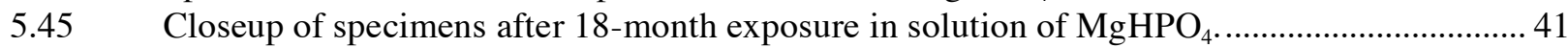

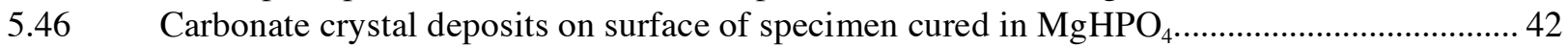

5.47 Comparison of length change results as function of time -18 month results.......................... 42

5.48 Comparison of weight change results as function of time -18 month results ........................... 46

5.49 Effect of curing period on compressive strength of 2-in.-cube specimens. .............................. 46

5.50 XRD spectrum from samples cured in phosphate solutions for 18 months .............................. 50

5.51 XRD spectrum of specimen cured in $\mathrm{MgHPO}_{4}$ before

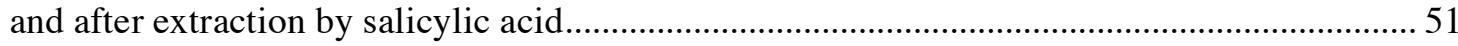

5.52 XRD spectrum of specimen cured in $\mathrm{Na}_{2} \mathrm{HPO}_{4}$ before

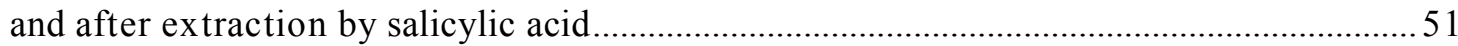

$5.53 \quad$ Main phases present in samples cured in $\mathrm{Na}_{2} \mathrm{HPO}_{4}$ solution...............................................5

5.54 Minor phases present in samples cured in $\mathrm{Na}_{2} \mathrm{HPO}_{4}$ solution .............................................54

5.55 Main phases present in samples cured in $\mathrm{MgHPO}_{4}$ solution ...............................................55

5.56 Minor phases present in samples cured in $\mathrm{MgHPO}_{4}$ solution ..............................................55

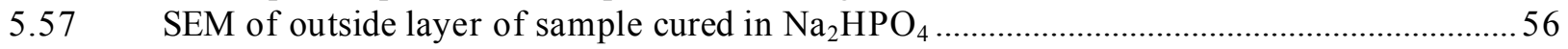

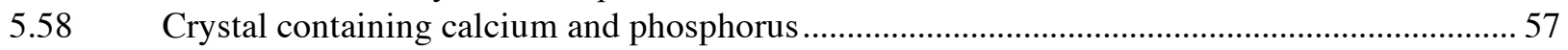

5.59 Crystals of calcium phosphate (possibly hydroxylapatite)

found in cement paste pore near outside surface 


\section{LIST OF TABLES}

Table

Page

2.1 Phosphate Replacement of $\mathrm{CaOH}_{2}$ in Ordinary Portland Cements (OPC) ............................... 3

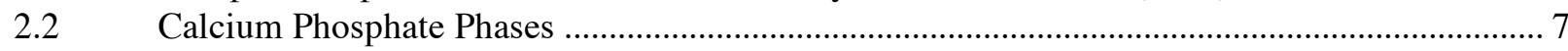

2.3 Precipitating Sequences of Calcium Phosphate Compounds

from Supersaturated Calcium Phosphate Solutions ….............................................................. 7

4.1 Summary of Contacts with Cognizant Concrete Research Organizations ................................ 15

5.1 One-Month Weight- and Length-Change Results for Specimens

Submerged in $\mathrm{Ca}(\mathrm{OH})_{2}$

5.2 One-Month Weight- and Length-Change Results for Specimens

Submerged in $\mathrm{Na}_{2} \mathrm{HPO}_{4}$

5.3 One-Month Weight- and Length-Change Results for Specimens

Submerged in $\mathrm{MgHPO}_{4}$.

5.4 One- and Three-Month Weight- and Length-Change Results

for Specimens Submerged in $\mathrm{Ca}(\mathrm{OH})_{2}$

5.5 One- and Three-Month Weight- and Length-Change Results

for Specimens Submerged in $\mathrm{Na}_{2} \mathrm{HPO}_{4}$

5.6 One- and Three-Month Weight- and Length-Change Results

for Specimens Submerged in $\mathrm{MgHPO}_{4}$

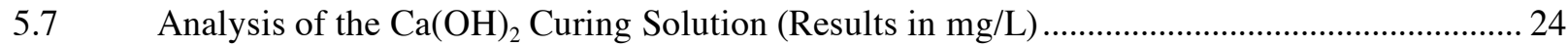

$5.8 \quad$ Analysis of the $\mathrm{MgHPO}_{4}$ Curing Solution (Results in $\mathrm{mg} / \mathrm{L}$ ) .............................................. 25

$5.9 \quad$ Analysis of the $\mathrm{Na}_{2} \mathrm{HPO}_{4}$ Curing Solution (Results in $\mathrm{mg} / \mathrm{L}$ ) ............................................ 25

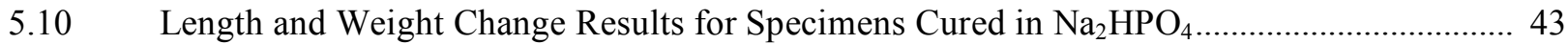

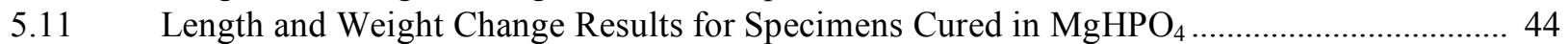

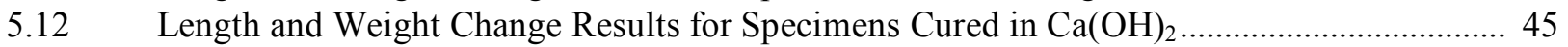

5.13 Compressive Strength Results for Specimens Cured in $\mathrm{Ca}(\mathrm{OH})_{2}$

for Periods up to 18 Months

5.14 Compressive Strength Results for Specimens Cured in $\mathrm{Na}_{2} \mathrm{HPO}_{4}$

for Periods up to 18 Months

5.15 Compressive Strength Results for Specimens Cured in $\mathrm{MgHPO}_{4}$

for Periods up to 18 Months

5.16 Analyses (in $\mathrm{mg} / \mathrm{L}$ ) of the $\mathrm{Na}_{2} \mathrm{HPO}_{4}$ solution before and

after contact with anhydrous or hydrated Portland cement ..................................................... 52

5.17 Analyses (in $\mathrm{mg} / \mathrm{L}$ ) of the $\mathrm{MgHPO}_{4}$ solution before and after contact with anhydrous or hydrated Portland cement

5.18 Analyses (in $\mathrm{mg} / \mathrm{L}$ ) of the $\mathrm{Ca}(\mathrm{OH})_{2}$ solution before and after contact with anhydrous or hydrated Portland cement 


\section{ACKNOWLEDGMENT}

The authors would like to acknowledge the continuing support and guidance throughout the program provided by the U.S. Nuclear Regulatory Commission Technical Monitor, Mr. Herman L. Graves, III. 


\section{INTRODUCTION}

\subsection{Background}

At the 499th Advisory Committee on Reactor Safeguards (ACRS) meeting, the NRC Staff presented its review results on the McGuire/Catawba Nuclear Stations License Renewal Applications. During the staff's presentation, one ACRS member asked the staff why a quantitative allowable phosphate limit is not included as part of the staff's acceptance criteria for defining aggressive ground water/soil environments in license renewal application reviews." The staff's response was that the current criteria for defining aggressive ground water/soil environments are primarily based on American Concrete Institute (ACI) standards and industry expert's opinion and believes that the current criteria are reasonable for defining ground water/soil aggressive environment. The staff also committed to take an in-depth review of the issue (i.e., if phosphate limits should be a part of the staff's criteria for aggressive ground water/soil environment).

In a letter dated June 24, 2003 to NRC Chairman Diaz, the Chairman of the Advisory Committee on Reactor Safeguards (ACRS), Dr. Mario Bonaca, made three recommendations. The third recommendation states, "The Generic Aging Lessons Learned Report (GALL) specifies limits for sulfate ion concentrations in below-grade water to avoid decrepitation of concrete. The staff should consider whether similar limits and guidance are needed for phosphate ion concentration." Based on the above ACRS recommendation, NRR User Need, NRR-2004-002, was developed and forwarded to RES for consideration in January 2004.

\subsection{Objectives}

The objectives of this limited study were to: (1) review the potential for degradation of cementitious materials due to exposure to high concentrations of phosphate ions; (2) provide an improved understanding of any significant factors that may lead to a requirement to establish exposure limits for concrete structures exposed to soils or ground waters containing high levels of phosphate ions; (3) recommend, as appropriate, whether a limitation on phosphate ion concentration in soils or ground water is required to avoid degradation of concrete structures; and (4) provide a "primer" on factors that can affect the durability of concrete materials and structures in nuclear power plants.

\subsection{Approach}

An assessment of the effects of phosphate ions on concrete materials and structures was made through a thermodynamic study of potential phosphate corrosion of ordinary Portland cements, a literature review of phosphates and cementitious materials, contacts with cognizant concrete researchers, and conduct of a "bench-scale" laboratory study to investigate the effect of different phosphate ion concentrations on strength and weight and length change of cubes and prisms fabricated from Portland cement paste. Results of the thermodynamic study, literature review, contacts with cognizant concrete researchers, and three-month experimental results were provided in a letter report. ${ }^{1}$ Interim results of the laboratory study (12-month exposure) were provided in a letter report. ${ }^{2}$ A report that can serve as a primer on factors that can affect the durability of concrete materials and structures in nuclear power plants has been prepared. ${ }^{3}$ Finally, this report has been prepared which incorporates results from the prior letter reports, updates experimental results (18-month exposure), and provides an assessment of the potential effects of phosphate ions on cementitious materials.

\footnotetext{
* Appendix A provides the basis for this action.
} 


\section{THERMODYNAMIC AND KINETIC RESULTS FOR PHOSPHATE CORROSION OF ORDINARY PORTLAND CEMENTS}

\subsection{Thermodynamic Results}

\subsubsection{Phosphate Replacement of Calcium Hydroxide}

Thermodynamic calculations were performed at ORNL using the thermodynamic database in Outokumpu's HSC Chemistry V5.11 code. ${ }^{4}$ These calculations substantiate the results in Appendix A that phosphate could replace calcium hydroxide $\left[\mathrm{Ca}(\mathrm{OH})_{2}\right]$ with calcium hydroxyapatite $\left[\mathrm{Ca}_{5}\left(\mathrm{PO}_{4}\right)_{3} \mathrm{OH}\right]$. In Table 2.1, these data show a very strong tendency for the formation of calcium hydroxyapatite.

Table 2.1 Phosphate Replacement of $\mathrm{CaOH}_{2}$ in Ordinary Portland cements (OPC)

\begin{tabular}{|c|c|c|c|c|c|}
\hline \multicolumn{6}{|c|}{$5 \mathrm{Ca}(\mathrm{OH})_{2}+3 \mathrm{PO}_{4}(-3 \mathrm{a})=\mathrm{Ca}_{5}\left(\mathrm{PO}_{4}\right)_{3} \mathrm{OH}+9 \mathrm{OH}(-\mathrm{a})$} \\
\hline $\mathbf{T}\left({ }^{\circ} \mathbf{C}\right)$ & $\Delta \mathrm{H}(\mathrm{kcal})$ & $\Delta \mathrm{S}(\mathrm{cal} / \mathrm{K})$ & $\Delta G($ kcal) & $\mathbf{K}$ & $\log (K)$ \\
\hline 0 & -7.725 & 127.84 & -42.64 & $1.33 \mathrm{E}+34$ & 34.122 \\
\hline 10 & -7.647 & 128.11 & -43.92 & $8.03 \mathrm{E}+33$ & 33.904 \\
\hline 20 & -7.391 & 129.00 & -45.21 & $5.08 \mathrm{E}+33$ & 33.706 \\
\hline 30 & -7.016 & 130.26 & -46.50 & $3.38 \mathrm{E}+33$ & 33.529 \\
\hline 40 & -6.563 & 131.73 & -47.81 & $2.36 \mathrm{E}+33$ & 33.372 \\
\hline 50 & -6.054 & 133.33 & -49.14 & $1.72 \mathrm{E}+33$ & 33.236 \\
\hline 60 & -5.497 & 135.02 & -50.48 & $1.31 \mathrm{E}+33$ & 33.118 \\
\hline 70 & -4.901 & 136.79 & -51.84 & $1.05 \mathrm{E}+33$ & 33.019 \\
\hline 80 & -4.271 & 138.60 & -53.22 & $8.63 \mathrm{E}+32$ & 32.936 \\
\hline 90 & -3.612 & 140.44 & -54.61 & $7.39 \mathrm{E}+32$ & 32.869 \\
\hline Formula & FM (g/mole) & Conc. (wt-\%) & Amt. (mol) & Amt. (g) & Vol. (ml) \\
\hline $\mathrm{Ca}(\mathrm{OH})_{2}$ & 74.095 & 56.527 & 5 & 370.473 & 165.39 \\
\hline $\mathrm{PO}_{4}(-3 \mathrm{a})$ & 94.971 & 43.473 & 3 & 284.914 & 0 \\
\hline $\mathrm{Ca}_{5}(\mathrm{PO} 4)_{3} \mathrm{OH}$ & 502.32 & 76.645 & 1 & 502.321 & 159.98 \\
\hline \multirow[t]{2}{*}{$\mathrm{OH}(-\mathrm{a})$} & 17.007 & 23.355 & 9 & 153.066 & 0 \\
\hline & & & & $\begin{array}{l}\text { Volume } \\
\text { Change = }\end{array}$ & $-3.3 \%$ \\
\hline
\end{tabular}

The negative $\Delta$ G's $(<-42 \mathrm{kcal} / \mathrm{mole})$ resulting in very large equilibrium coefficients $\left(\mathrm{K}>10^{33}\right)$ show that this reaction is spontaneous and that the reaction equilibrium goes from left to right as written in Table 2.1 (calcium hydroxyapatite density of $\sim 3.08 \mathrm{gm} / \mathrm{ml}$ ). Compared to the conversion of calcium hydroxide to calcite $\left(\mathrm{CaCO}_{3}\right)$, which naturally occurs in OPC's exposed to air and ground waters and results in a $\sim 4 \%$ volume increase, the formation of phosphates results in a net volume decrease of $3.3 \%$ compared to the calcium hydroxide conversion (i.e., $3.87 \%$ increase vs $4 \%$ increase).

Since the reaction in Table 2.1 only describes the reactions of calcium hydroxide and phosphate ions in an isolated system, we looked to see if this strong reaction could compete with the calcium aluminosilicates 
that are formed in OPC matrices. Figure 2.1 shows the equilibrium phases for an OPC system that is inundated with phosphate ions.

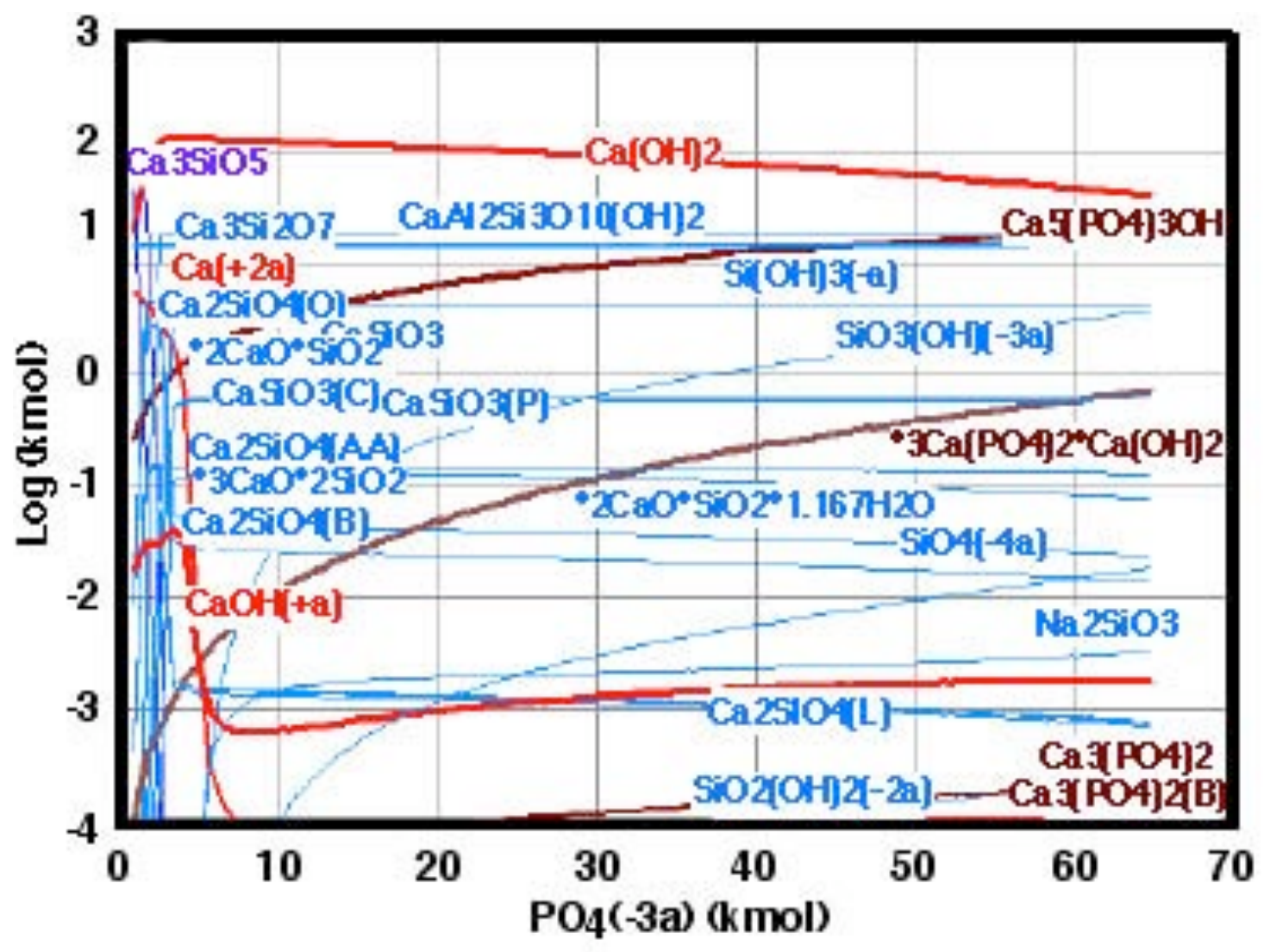

Figure 2.1 Phases in OPC that form under increasing exposure to phosphate (calcium hydroxide, aluminosilicates, and phosphate phases).

These data show that in an OPC system the formation of calcium hydroxyapatite is still capable of replacing the free calcium hydroxide (Portlandite) and competes successfully for calcium in aluminosilicate matrices.

\subsubsection{Study of Phosphate Concentrations Controlled by Soil Minerals}

Depending on its origins in a particular soil system, the dominant cations may be calcium $(\mathrm{Ca})$ with magnesium $(\mathrm{Mg})$, and/or sodium $(\mathrm{Na})$. Therefore these elements will determine the phosphate solubilities in the soil porewaters. Anticipating the design of laboratory exposure tests and the evaluation of field exposure results, we calculated the relative phosphate solubilities as they would be controlled by the respective phosphate compounds.

Figures 2.2, 2.3, and 2.4 show the sodium, magnesium, and calcium phosphate systems, respectively, and the saturation aqueous phosphate concentrations. In these three cases, one mole of solid was placed on one liter of water and the equilibrium concentrations were calculated using Outokumpu HSC V5.11 system free energy minimization code and thermodynamic database. ${ }^{4}$ Respectively, the one mole of solids were sodium hydrogen phosphate dodecahydrate $\left(\mathrm{Na}_{2} \mathrm{HPO}_{4} * 12 \mathrm{H}_{2} \mathrm{O}\right)$, magnesium phosphate $\left(\mathrm{Mg}_{3}\left(\mathrm{PO}_{4}\right)_{2}\right)$, and calcium hydrogen phosphate dihydrate $\left(\mathrm{CaHPO}_{4} * 2 \mathrm{H}_{2} \mathrm{O}\right)$. These compounds saturated 
the aqueous systems to the ranges of $10^{-1}, 10^{-3}$, and $10^{-5}$ molar, respectively. This shows that calcium rich cements and limestone/dolomite aggregates will extract phosphate from nearly all common ground waters.

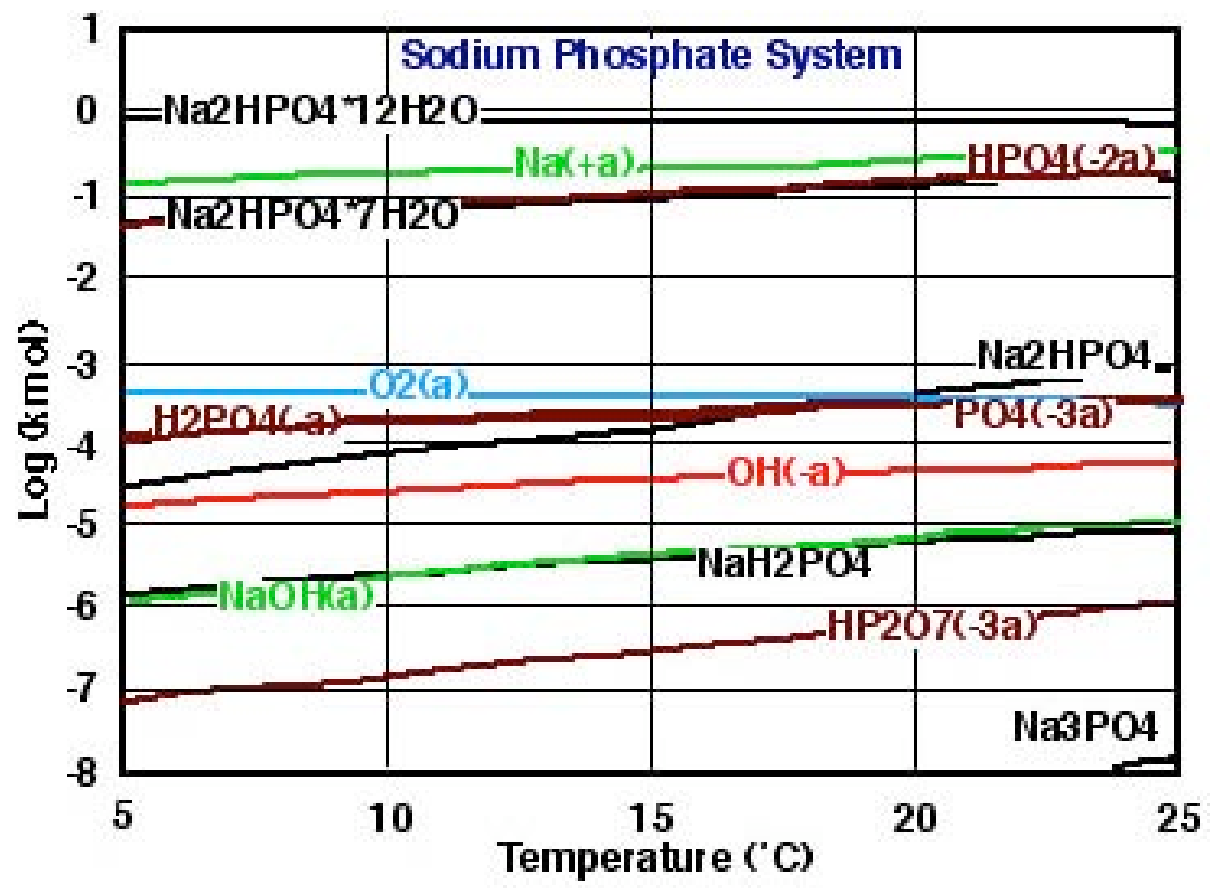

Figure 2.2 At equilibrium, sodium rich systems saturate the phosphate aqueous system to phosphate concentrations in the $10^{-1}$ molar range.

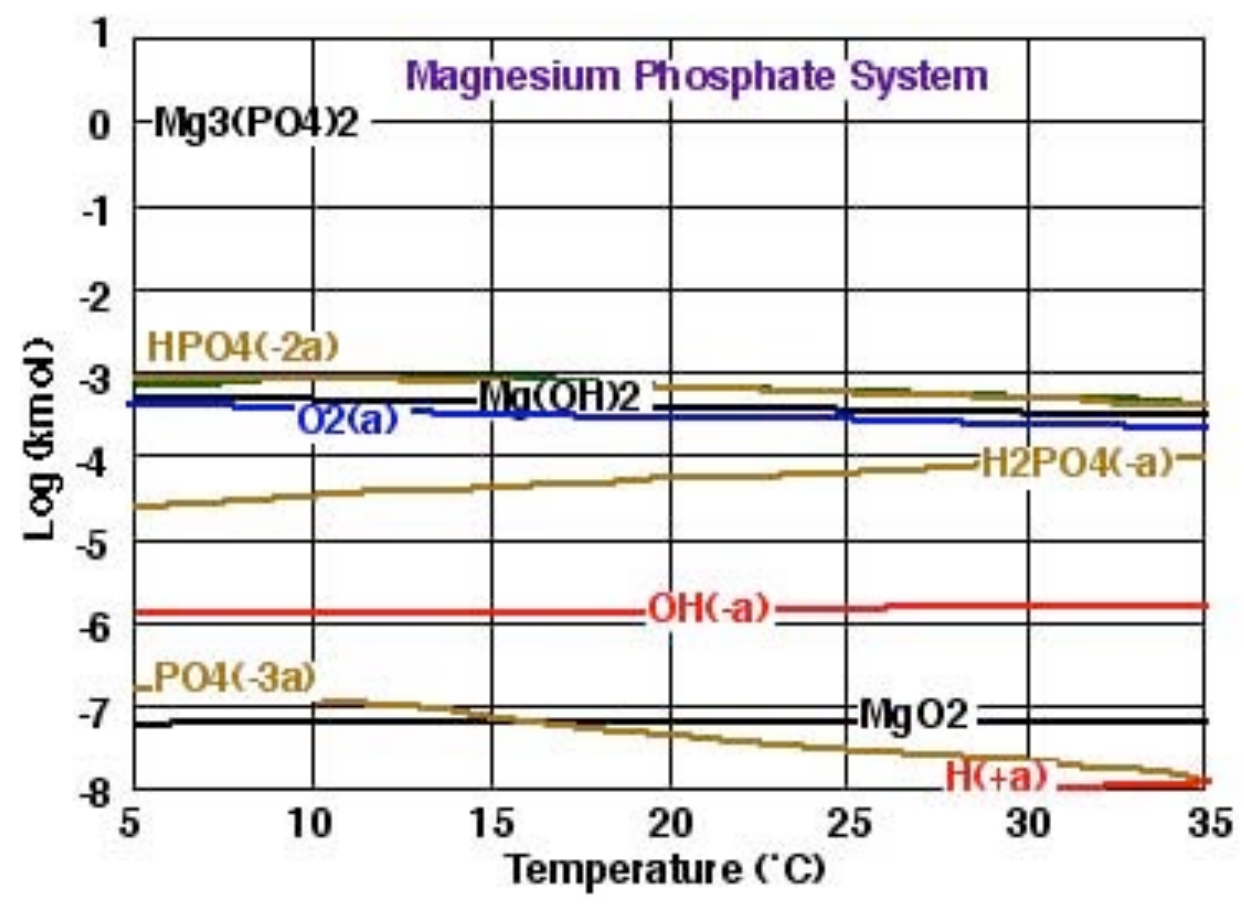

Figure 2.3 At equilibrium, magnesium rich systems saturate the phosphate aqueous system to phosphate concentrations in the $10^{-3}$ molar range. 


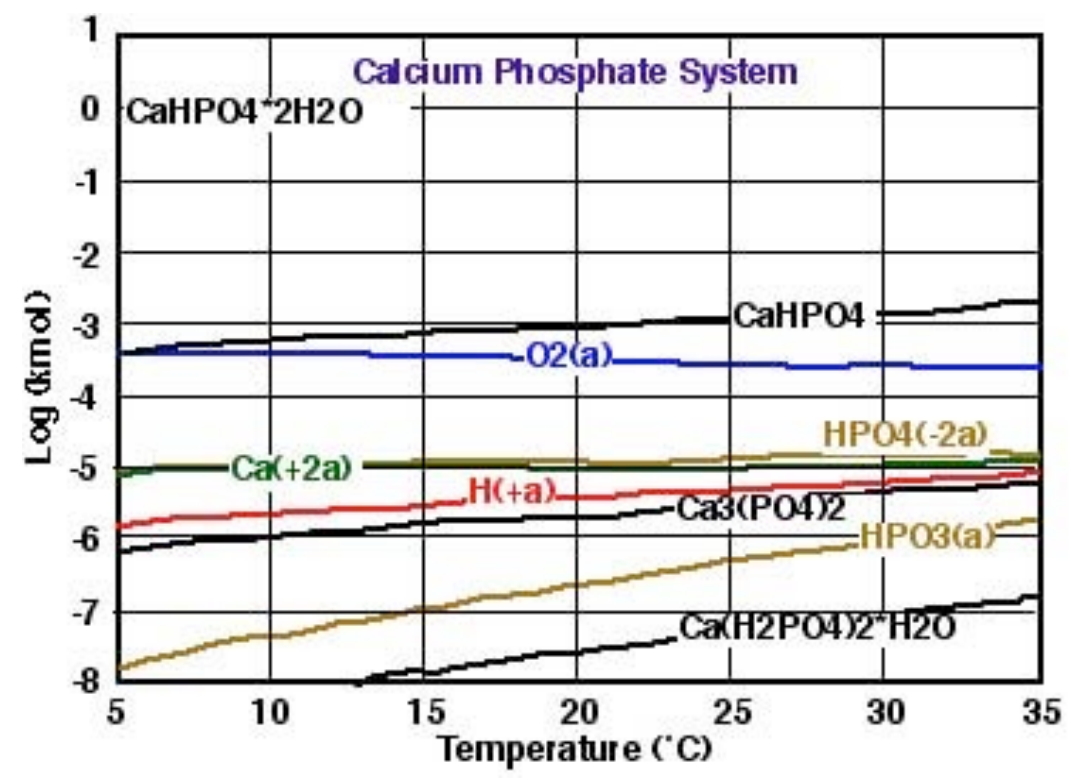

Figure 2.4 At equilibrium, calcium rich systems saturate the phosphate aqueous system to phosphate concentrations in the $10^{-5}$ molar range.

During exposure testing of cement, aggregates, and concretes, the leachates' phosphate concentrations can be buffered for the duration of the testing by adding excess sodium hydrogen phosphate dodecahydrate $\left(\mathrm{Na}_{2} \mathrm{HPO}_{4} * 12 \mathrm{H}_{2} \mathrm{O}\right)$ and magnesium phosphate $\left[\mathrm{Mg}_{3}(\mathrm{PO} 4)_{2}\right]$. Therefore, during a static exposure test a constant phosphate concentration can be maintained with these compounds.

In a cement-dolomite aggregate system exposed to $\mathrm{CO}_{2}$ in the air or ground water, Figure 2.5, calcium in the cement-aggregate system will extract phosphate from the solution and form calcium hydroxyapatite, as shown to be stable in $\mathrm{SiO}_{2} * \mathrm{Al}_{2} \mathrm{O}_{3} * \mathrm{CaO}$ systems.

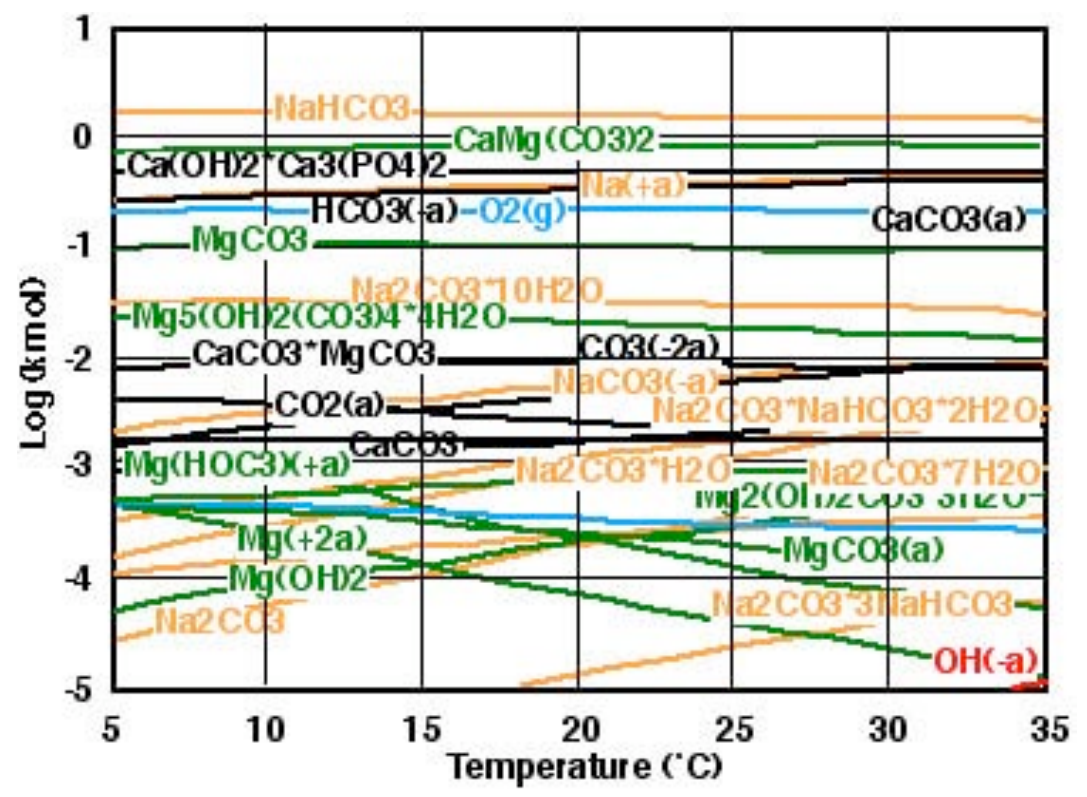

Figure 2.5 Calcium hydroxyapatite forms in $\mathrm{Na}^{*} \mathrm{Mg} * \mathrm{Ca}$ systems in presence of $\mathrm{CO}_{2}$ from air or ground water. 


\subsection{Kinetic Results - Formation of Crystalline Calcium Phosphates}

The formation of three different crystalline calcium phosphates (Brushite, Octacalcium Phosphate, and Hydroxyapatite) and an amorphous calcium phosphate was studied as a function of $\mathrm{pH}$ and supersaturation at the Van't Hoff Laboratory of the Debye Institute in Utrecht, The Netherlands. ${ }^{5}$ In high or medium supersaturated solutions formation of apatite always seems to be preceded by the precipitation of one or more precursor phases. Table 2.2 provides a listing of calcium phosphate phases indicating that the phosphates precipitate in a sequence of compounds. At lower $\mathrm{pH}$ the calcium hydroxyapatite is preceded by octacalcium phosphate and brushite. ${ }^{5}$ Thus these phosphates will act as precursors for formation of calcium hydroxyapatite since the calcium hydroxyapatite is the most thermodynamically stable phase.

Table 2.2 Calcium Phosphate Phases

\begin{tabular}{|c|c|c|c|}
\hline Phase & Abbreviation & Compound & $\mathrm{Ca} / \mathbf{P}^{*}$ \\
\hline Brushite & DCPD & $\mathrm{CaHPO}_{4} \cdot 2 \mathrm{H}_{2} \mathrm{O}$ & 1 \\
\hline Monetite & DCPA & $\mathrm{CaHPO}_{4}$ & 1 \\
\hline Octacalcium Phosphate & $\mathrm{OCP}$ & $\mathrm{Ca}_{4} \mathrm{H}\left(\mathrm{PO}_{4}\right)_{3} \cdot 2.5 \mathrm{H}_{2} \mathrm{O}$ & 1.33 \\
\hline Whitlockite / Tricalcium Phosphate & TCP & $\mathrm{Ca}_{3}\left(\mathrm{PO}_{4}\right)_{2}$ & 1.5 \\
\hline Calcium Hydroxyapatite & HAP & $\mathrm{Ca}_{5}\left(\mathrm{PO}_{4}\right)_{3} \mathrm{OH}$ & 1.67 \\
\hline Amorphous Calcium Phosphate & $\mathrm{ACP}$ & - & - \\
\hline \multicolumn{4}{|c|}{$\begin{array}{l}\text { Source: M. J. J. M. van Kemenade and P. L. de Bruyn, "A Kinetic Study of Precipitation from } \\
\text { Supersaturated Calcium Phosphate Solutions," Journal of Colloidal and Interface Science 118(2), } \\
\text { pp. 564-585, August } 1987 . \\
\text { *Ratio of total calcium to phosphate. }\end{array}$} \\
\hline
\end{tabular}

The precipitating sequences observed in Ref. 5 for the different experimental conditions investigated are summarized in Table 2.3. These results show that the order in which the solid phases precipitate is associated with increasing phase stability as dictated by the experimental conditions. At low supersaturations homogeneous formation of the most stable phase (HAP) is to be expected as the solution would be saturated or even undersaturated with respect to the other phases, but HAP was never observed to form homogeneously. For HAP growth to occur, the presence of a precursor was required at all times. This is in agreement with results reported by others who studied precipitation of calcium phosphate from moderately acid solutions ${ }^{6}$ and the lifetime of an ACP precursor as a function of supersaturation. ${ }^{7}$

Table 2.3 Precipitating Sequences of Calcium Phosphate Compounds from Supersaturated Calcium Phosphate Solutions

\begin{tabular}{|c|c|c|l|}
\hline $\mathbf{p H}$ & $\mathbf{T}\left({ }^{\circ} \mathbf{C}\right)$ & Precipitation Sequence & \multicolumn{1}{c|}{ Comment } \\
\hline 6.7 & 26 & DCPD $=$ OCP $\longrightarrow$ HAP & $\begin{array}{l}\text { Initially OCP forms at medium saturation at } \\
\text { exclusion of all other phases }\end{array}$ \\
\hline 7.4 & 26 & ACP $\longrightarrow$ OCP $\longrightarrow$ HAP & ACP dominates initial phase at high pH \\
\hline 6.0 & 26 & OCP $\longrightarrow$ DCPD $(\longrightarrow)$ HAP & HAP is the most thermodynamically-stable phase \\
\hline 6.7 & 37 & DCPD $\longrightarrow$ OCP $\longrightarrow$ HAP & $\begin{array}{l}\text { Homogeneous formation of HAP even at low } \\
\text { supersaturation was never seen }\end{array}$ \\
\hline $\begin{array}{l}\text { Source: M. J. J. M. van Kemenade and P. L. de Bruyn, "A Kinetic Study of Precipitation from } \\
\text { Supersaturated Calcium Phosphate Solutions," Journal of Colloidal and Interface Science 118(2), } \\
\text { pp. 564-585, August 1987. }\end{array}$
\end{tabular}




\subsection{Commentary}

Thermodynamic calculations performed using Outokumpu's HSC Chemistry V5.11 code substantiate the results in Appendix A indicating that phosphate could replace calcium hydroxide $\left[\mathrm{Ca}(\mathrm{OH})_{2}\right]$ with calcium hydroxyapatite $\left[\mathrm{Ca}_{5}\left(\mathrm{PO}_{4}\right)_{3} \mathrm{OH}\right]$. Kinetic results presented in the literature indicate that in high or medium supersaturated solutions formation of hydroxyapatite always seems to be preceded by the precipitation of one or more precursor phases. Homogeneous formation of hydroxyapatite even at low supersaturtion was never seen. 


\section{LITERATURE REVIEW - PHOSPHATES AND CEMENTITIOUS MATERIALS}

\subsection{Phosphates and Fertilizer Production*}

Phosphate deposits exist all over the world. The principal commercial deposits of phosphate rock in the United States exist in Florida, North Carolina, and Idaho, with lesser amounts in Utah and Montana. The phosphate mineral, as it exists in the ground, is not soluble in water and thus is hard for vegetation to access. After the phosphate is separated from the sand and clay at the beneficiation plant it goes to the processing plant. There it is finely ground to uniform size and reacted with sulfuric acid to create the phosphoric acid which is concentrated through evaporation, reacted with ammonia, and granulated to produce diammonium phosphate (DAP) and monoammonium phosphate (MAP). Granular triple superphosphate (GTSP), a non-nitrogen fertilizer, is produced by adding phosphoric acid to ground phosphate rock. DAP fertilizer is water-soluble and is available for vegetation to take up through its roots. When sulfuric acid is reacted with phosphate rock to produce phosphoric acid a by-product is produced. This by-product gypsum is called phosphogypsum. There are approximately five tons of phosphogypsum produced for every ton of phosphoric acid product produced. Phosphogypsum, like natural gypsum, is calcium sulfate, but it contains a small amount of radioactivity due to the radium that naturally occurs in Florida phosphate rock.

Production of fertilizer also requires/produces a large volume of process water. This is the water source for the phosphoric acid, gas scrubbing, phosphogypsum slurry for transportation and storage, operation of condensers, as well as other uses in the chemical complex. The process water has a $\mathrm{pH}$ of about 1 to 2 and contains a dilute mixture of phosphoric, sulfuric, and fluosilic acids. The process water is saturated with calcium sulfate and contains numerous other ions found in phosphate rock, as well as ammonia from the solid fertilizer-manufacturing process. The process water is treated with lime to raise the $\mathrm{pH}$ to about 4.5, any solids formed are removed, lime the water to a $\mathrm{pH}$ of about 11, again remove solids formed, air strip the water to remove ammonia, and add acid to reduce the $\mathrm{pH}$ to about 6.5 .

\subsection{Phosphates and Cementitious Materials}

A review of the literature was conducted to identify information related to interactions of phosphate ions and cementitious materials, phosphates incorporated into cementitious materials, and utilization of phosphate-related materials in the infrastructure.

A chemical analysis approach has been utilized to determine the mechanism for concrete scaling on aircraft parking aprons. ${ }^{8}$ The study was part of a multi-task Navy investigation on thermal and chemical deterioration of concrete parking aprons used for F/A-18 aircraft maintenance. The Navy has observed that the concrete pavement is damaged either by aircraft chemicals, heat from the Navy F/A-18 aircraft auxiliary power unit (APU), or a combination of both. An acid attack hypothesis has been developed involving the engine oil which contains a large number of additives. Among the additives are tricresyl orthophosphate and triphenyl phosphite which help lubricate steel and reduce wear due to heat and friction. A small amount of red phosphorus is added to the engine oil to act as a scavenger for oxygen and water. The phosphorus can oxidize to phosphoric oxides that produce phosphorous and phosphoric acids. Tricresyl phosphate can be decomposed into cresol and phosphoric acid that can readily attack the concrete in a manner similar to nitric or hydrochloric acids. The red phosphorous can be oxidized in air

\footnotetext{
* Source: Florida Institute of Phosphate Research, "Phosphate Primer," http://www.fipr.state.fl.us.
} 
to form phosphorus pentoxide that can react with moisture to form phosphoric acid. Finally, the triethyl orthophosphate, a corrosion inhibitor additive, can break down in the presence of acid, moisture, and heat to form phosphoric acid and ethanol. It was hypothesized that the oil containing the acids drips onto the pavement and gradually decomposes the calcium carbonate or the cement paste (e.g., calcium aluminates and silicates) at the surface of the concrete into calcium phosphate to form a weak surface layer. Heat from the APU accelerates this reaction. Forensic chemical analysis was used in determining the mechanism of the concrete scaling. Concrete debris from the airfield were extracted with hexane and the hexane evaporated to leave an organic residue. The organic residue was analyzed by infrared spectroscopy and mass spectrometry. The extract consisted of ethanol, phenol, and other byproducts expected from the decomposition of the organophosphate compounds used as antioxidants in the engine oil. After the concrete was extracted with hexane, it was analyzed by x-ray fluorescence (XRF) and electron scanning chemical analysis (ESCA). The results indicated that the material contained calcium phosphate. The calcium phosphate came from decomposition of the pavement by phosphoric acid. Thus it was established that the phosphoric acid did originate from the phenyl orthophosphate and traces of red phosphorus used in the engine oil. It is suggested that engineers mitigate the acidic erosion of the concrete either by: (a) replacing the portland cement concrete in the parking apron area with an acid resistant concrete (aluminum or magnesium phosphate concrete), or (b) recommending Military Specification (MILSPEC) engine oils without the acid-forming additives. It was also noted that current acid damage to the concrete can be lessened by periodically cleaning the affected pavement with a suitable alkaline detergent ( $\mathrm{pH} 10$ or higher), such as aqueous trisodium phosphate (TSP).

A study was conducted to assess the capacity of sorption of various ions in calcium silicate hydrates. ${ }^{9}$ Chloride ion, sulfate ion, and phosphate ion were sorbed in synthesized calcium silicate hydrates (C-S-H). The amount of sorbed chloride ion, sulfate ion, and phosphate ion in C-S-H were 172, 54, and $667 \mathrm{mg} / \mathrm{g}$, respectively. In the case of sorption of phosphate ion, the phosphate ion and C-S-H reacted to produce hydroxyapatite. In the leaching test, $15 \%$ chloride ion, $18 \%$ sulfate ion, and $34 \%$ phosphate ion were dissolved from C-S-H sorbing respective cations; while, $65 \%$ of fixed chloride ion in Friedel's salt was dissolved in the leaching test. Therefore, the fixing ability of chloride ion in C-S-H is higher than that in Friedel's salt.

Small amounts of phosphorus pentoxide $\left(\mathrm{P}_{2} \mathrm{O}_{5}\right)$ in the raw materials used for the manufacture of cement, such as can occur in some limestones, can cause problems. ${ }^{10}$ The content of $\mathrm{P}_{2} \mathrm{O}_{5}$ in most Portland cements is of the order of $0.2 \%$; however, satisfactory cements can be manufactured from cement clinker containing up to $2.5 \% \mathrm{P}_{2} \mathrm{O}_{5}$ by correct burning and proportioning, but the rate of hardening is slower. This is because the $\mathrm{P}_{2} \mathrm{O}_{5}$ decomposes $\mathrm{C}_{3} \mathrm{~S}$ forming a series of solid solutions between $\mathrm{C}_{2} \mathrm{~S}$ and $3 \mathrm{CaO} \cdot \mathrm{P}_{2} \mathrm{O}_{5}$. If larger amounts of $\mathrm{P}_{2} \mathrm{O}_{5}$ are present, free lime forms. If the lime content is reduced so that free $\mathrm{CaO}$ is not formed, sound cements can be burnt from phosphatic raw materials but they develop strength more slowly because of the reduced $\mathrm{C}_{3} \mathrm{~S}: \mathrm{C}_{2} \mathrm{~S}$ ratio. It is also noted in this reference that basic phosphate salts, including even ammonium salt, do not appear to have any serious action on concrete, but definite information is not available on acid salts.

Portland cements are not resistant to attack by acids. The degree of attack increases as the acidity increases; attack occurs at values of $\mathrm{pH}$ below about 6.5, a $\mathrm{pH}$ less than 4.5 results in severe attack. The rate of attack also depends on the ability of hydrogen ions to be diffused through the cement gel (C-S-H) after $\mathrm{Ca}(\mathrm{OH})_{2}$ has been dissolved and removed by leaching. Phosphates present in the form of phosphoric acid will cause slow disintegration of Portland cement-based materials. ${ }^{11,12}$ Free phosphoric acid, as it is found in superphosphate, attacks cement and concrete and forms calcium phosphate, which has an acid reaction. ${ }^{13}$ A more dangerous component in superphosphate, especially in ammonium superphosphate, is the free sulphuric acid, which causes sulphate destruction. Crude phosphates are noted to be harmless to concrete. 
Some inorganic salts (e.g., borates, phosphates, and zinc and lead salts) can act as retarders, but are not used commercially. ${ }^{14} \mathrm{Up}$ to $500 \mathrm{ppm}$ can generally be tolerated in mix water without causing significant set retardation. Basic research on the effect of retarders has shown that they slow down the rate of early hydration of $\mathrm{C}_{3} \mathrm{~S}$ by extending the length of the dormant period (i.e., second stage of hydration). Thus the setting time of Portland cement, as measured by the penetration test, is extended. The extension of the dormant period is proportional to the amount of retarding admixture used, and when the dosage exceeds a certain critical point, the $\mathrm{C}_{3} \mathrm{~S}$ hydration will never proceed beyond the dormant stage and the cement will not set. Retarders also tend to delay the hydration of $\mathrm{C}_{3} \mathrm{~A}$ and related aluminate phases. The retarding action of sodium salts of phosphoric acid has been noted. ${ }^{15}$ Sodium salts of phosphoric, boric, oxalic, and hydrofluoric acid are soluble, but the calcium salts are highly insoluble and therefore readily form in the vicinity of hydrating cement particles. Once insoluble and dense coatings are formed around cement grains, further hydration slows down considerably. Phosphates are commonly found to be present as ingredients of commercial set-retarding admixtures. The influence of a phosphonate-based admixture called aminotri (methylene phosphonic acid) (ATMP) on the hydration of $\mathrm{C}_{3} \mathrm{~A}, \mathrm{C}_{3} \mathrm{~A}$ and 25 percent gypsum, and $\mathrm{C}_{3} \mathrm{~S}$ and Type I Portland cements (normal, high-alkali, and low-alkali) was evaluated. ${ }^{16}$ Isothermal conduction calorimetric investigations of various mixes containing 0.03 to 0.05 percent of phosphonic acid, at water-cement ratios of 0.35 and 1.0, were carried out at times up to $72 \mathrm{hr}$. The ATMP acted as a super-retarder for all mixes studied. At a dosage of only 0.05 , the exothermal effect for one of the high-alkali Type I cements was delayed by about $16 \mathrm{hr}$. The hydration of $\mathrm{C}_{3} \mathrm{~A}$ and $\mathrm{C}_{3} \mathrm{~S}$ was also retarded by about 40 to $45 \mathrm{~min}$ and more than $50 \mathrm{hr}$, respectively, at a dosage of 0.05 percent. In the $\mathrm{C}_{3} \mathrm{~A}$ and gypsum system, the third peak corresponding to the reaction of $\mathrm{C}_{3} \mathrm{~A}$ with ettringite was extended by about 8 to $9 \mathrm{hr}$.

Alkali-silica expansion is produced by an alkali-rich gel imbibing low-alkali water by osmosis. The amount of gel produced is a function of the available reactive silica and the alkalis, as well as the distribution and distance between the reactive silica particles within the mortar or concrete for a given content of alkalis. One method to immobilize the alkali cation is to bind the alkalis to a strong anion. One such anion is that of phosphate which is strongly electronegative and will attract any cation. Monocalcium phosphate monohydrate and mono-potassium phosphate when added to the concrete mixture containing reactive aggregates have shown to reduce the expansion resulting from alkali-silica reactions. ${ }^{17}$

Monoflurophosphate has been used as a corrosion inhibitor for concrete steel reinforcement over the last 20 years. ${ }^{18}$ It is applied at the concrete surface in the form of an aqueous solution with a mass percentage ranging from between $10 \%$ and $20 \%$. The $\mathrm{PO}_{3} \mathrm{~F}^{2-}$ ions perform the inhibiting action. By forming apatites with calcium-containing compounds when the concrete has not been carbonated, $\mathrm{PO}_{3} \mathrm{~F}^{2-}$ ions are trapped but reaction products may accumulate in parts of the porous network to block penetration of aggressive species. The effectiveness of monoflurophosphate is based on both its diffusion into the concrete pore network and its action on the steel reinforcement surface. Monoflurophosphate appears to be most effective in the treatment of carbonated concrete since under this condition it is able to penetrate to greater depths.

Phosphate cement systems, because of their quick setting property, have also been utilized in many civil engineering repair applications. ${ }^{19}$ Different methods can be used to produce phosphate cements: (1) reaction of metal oxides with phosphoric acid; (2) reaction of acid phosphates with weakly basic or amphoteric oxides; (3) reaction of siliceous materials with phosphoric acid; and (4) reaction of metal oxides with ammonium phosphates, magnesium acid phosphates, aluminum acid phosphates, and other metal phosphates. ${ }^{20}$ Magnesium phosphate cements are formed by the reaction of a solid basic magnesia powder (e.g., $\mathrm{MgO}$ ) with a soluble phosphate, such as ammonium phosphate, either the mono or dibasic salt; or an agricultural fertilizer solution. ${ }^{21}$ A phosphate cement-based binder for rapid repair of concrete 
has been developed by mixing magnesium oxide $(\mathrm{MgO})$ powder with $\mathrm{NH}_{4} \mathrm{H}_{2} \mathrm{PO}_{4}$ powder and borax powder. ${ }^{22}$ A magnesium phosphate cement having quick set, high early strength, and good durability has been produced from acid-base reaction of magnesia and phosphates. ${ }^{23}$ The magnesia cements have very good adhesion to a wide variety of aggregates and substrates as well as good water and freeze-thaw resistance. Phosphate cements have also been prepared by an acid-base reaction between $\mathrm{MgO}$ and $\mathrm{KH}_{2} \mathrm{PO}_{4}{ }^{24}$ The resulting product of the reaction is a binder having a pH between 7 and 8 . The binder is then mixed with a silica-based material, such as fly ash, blast furnace slag, or vitreous tuff, to produce a phospho-silicate cement. Phosphate-based additions to high-alumina cements have resulted in increased reactivity that in turn produces higher strengths. ${ }^{25}$ Aluminum phosphate cement, possessing high early strength and increasing long-term strength, has been produced by hydrothermal-caltalyzed acid-base reaction between alumina and $\mathrm{NH}_{4} \mathrm{H}_{2} \mathrm{PO}_{4}{ }^{26}$ Also, there are silica-phosphate materials that have been investigated as inexpensive engineering building materials fabricated from local raw materials to produce ceramics, thermal bricks, and blocks characterized by solid physical, dynamical and chemical properties. $^{27}$

As noted in the previous section, phosphogypsum is produced in significant amounts as a by-product of the phosphate fertilizer industry (i.e., about 30 million tons per year). ${ }^{28}$ Its main constituent is calcium sulfate dihydrate. When compacted, the phosphogypsum can be transformed into a solid that has potential application for road building as well as a construction material. Potential applications cited include: a road base that is cheaper and as effective, if not more, as current road base materials; an agricultural soil amendment that would provide much needed sulfur to the soil; a landfill cover to speed the degradation of waste and extend the landfill life; a material to make glass-ceramic wall, floor, and roofing tiles; and a material for marine substrate, such as oyster culch. Considerable research on use of phosphogypsum for building materials has been conducted at the University of Miami. ${ }^{29,30}$ If somewhat longer initial and final setting times can be tolerated, it has been demonstrated that phosphogypsum can be rendered suitable for use as a set retarder by subjecting it to washing with dilute acid solutions or dilute basic solutions. ${ }^{31}$ Researchers at the University of Miami also have indicated that since phosphogypsum is a very fine material that possesses good binding properties under compaction, it exhibits potential for use in roller compacted concrete. ${ }^{30}$ Demonstration driveways and parkways have been constructed using this technology at the Florida Institute of Phosphate Research in Bartow, Florida. Durability of the phosphogypsum-based concrete is attained through proper combination of phosphogypsum and tricalcium aluminate content in the cementitious material.

Calcium phosphate-based systems have wide application in the biomedical area since they are capable of rapidly setting to a hard mass and are highly biocompatible. ${ }^{32,33}$ A similarity exists between the hydration of calcium silicates and calcium phosphates in that the hydration products in both systems have high surface areas, variable composition, and poor crystallinity. ${ }^{34}$ Calcium phosphate cements are materials that are capable of rapidly setting to a hard mass and are highly biocompatible.

Additional information on phosphates and cementitious materials is available. ${ }^{35-60}$

\subsection{Commentary}

A review of the literature did not identify any pertinent information relative to harmful interactions of phosphate ions and cementitious materials. Where phosphate was present and degradation of concrete occurred, this was generally due to phosphate being in the form of phosphoric acid which is known to cause degradation of Portland cement-based materials. Phosphate compounds have been included in

\footnotetext{
* Source: Florida Institute of Phosphate Research, "Phosphate Primer," www.fipr.state.fl.us.
} 
concrete mixes as set retarders. A number of cement-based binders or phosphate cements have been produced for civil-engineering repair applications to take advantage of their quick setting capability. Several of the articles addressed apatite and dental applications. Finally, phosphogypsum, a main byproduct of the phosphate industry, has been evaluated for application as a road base material and set retarder for Portland cement concretes. 


\section{CONTACTS WITH COGNIZANT CONCRETE RESEARCH ORGANIZATIONS}

Contacts have been made with a number of concrete researchers and concrete research organizations. In addition several organizations involved in the phosphate industry were contacted. Table 4.1 identifies several of the organizations contacted and a summary of response provided.

Table 4.1 Summary of Contacts with Cognizant Organizations

\begin{tabular}{|c|c|}
\hline Organization & Comment \\
\hline $\begin{array}{l}\text { Dept. of Civil Engineering } \\
\text { University of Florida } \\
\text { Gainesville, Florida }\end{array}$ & $\begin{array}{l}\text { Working on program to evaluate residual effects of phosphates in waste. } \\
\text { Phosphates may produce a set-retarding effect. Heard that phosphates may } \\
\text { increase corrosion potential, but this is unsubstantiated. }\end{array}$ \\
\hline $\begin{array}{l}\text { Materials Science \& Eng. } \\
\text { Penn State University } \\
\text { University Park, PA }\end{array}$ & $\begin{array}{l}\text { If phosphate ion intruded the pore structure of concrete two possible outcomes } \\
\text { would be expected: (1) in carbonated zone there would be a slow reaction with } \\
\mathrm{CaCO}_{3} \text { to form HAP, but will depend on cation associated with phosphate; }(2) \text { if } \\
\text { phosphate intrudes non-carbonated zone, HAP would form as } \mathrm{Ca}(\mathrm{OH})_{2} \text { is } \\
\text { consumed. From a phase equilibria standpoint HAP is compatible with hydrated } \\
\text { cement paste. With respect to expansion, because products formed are } \\
\text { microcrystalline, it is not expected that expansion would be a problem. }\end{array}$ \\
\hline $\begin{array}{l}\text { Building Research Establishment } \\
\text { Garston, Watford, UK }\end{array}$ & $\begin{array}{l}\text { A literature search at BRE did not identify any research related to phosphate } \\
\text { ions and concrete. Current researchers at BRE are not aware of any research at } \\
\text { BRE or elsewhere in UK involving phosphate ions and concrete materials. }\end{array}$ \\
\hline Concrete Consultant & $\begin{array}{l}\text { Not aware of work addressing phosphates and concrete except that ACI } \\
201 \text {,"Durability," notes that concrete can undergo moderate disintegration when } \\
\text { subjected to phosphoric acid. Some research has been conducted on systems } \\
\text { that rely on hydration or reaction of phosphate compounds because they have } \\
\text { rapid strength development. Information on this topic is available: A.K. } \\
\text { Chatterji, "Special and New Cements," Proc. } 9^{\text {th }} \text { Int'l Congress on Chemistry of } \\
\text { Cements, pp. } 177-212 \text {, New Delhi, } 1992 .\end{array}$ \\
\hline $\begin{array}{l}\text { Structural Materials Lab } \\
\text { Florida DOT } \\
\text { Gainesville, Florida }\end{array}$ & $\begin{array}{l}\text { Phosphate ion contents have been determined for soils and water adjacent to } \\
\text { transportation structures in Florida. Not aware of any problems or special } \\
\text { design procedures being utilized for concrete structures located in high } \\
\text { phosphate environments. }\end{array}$ \\
\hline $\begin{array}{l}\text { State Corrosion Engineer } \\
\text { Florida DOT } \\
\text { Gainesville, Florida }\end{array}$ & Not aware of any problems involving phosphates and reinforced concrete. \\
\hline $\begin{array}{l}\text { Immobilisation Science Lab. } \\
\text { University of Sheffield, UK }\end{array}$ & $\begin{array}{l}\text { Not aware of any problems involving phosphates and concrete. Main effect is } \\
\text { thought to be a potential buildup of products on exterior surface of concrete. }\end{array}$ \\
\hline $\begin{array}{l}\text { CTL Group } \\
\text { Skokie, Illinois }\end{array}$ & $\begin{array}{l}\text { Only information is related to phosphoric acid causing acid attack; ACI 515.1- } \\
79 \text { notes that } 10 \text { to } 85 \% \text { phosphoric acid causes concrete to disintegrate slowly. }\end{array}$ \\
\hline $\begin{array}{l}\text { Consultant } \\
\text { British Cement Association } \\
\text { Camberly, Surrey, UK }\end{array}$ & $\begin{array}{l}\text { Unaware of any significant work in UK on phosphates as it has not been } \\
\text { identified as a major problem }\end{array}$ \\
\hline $\begin{array}{l}\text { University of New Brunswick, } \\
\text { Fredericton, Canada }\end{array}$ & $\begin{array}{l}\text { Not aware of problems. Fertilizer runoff could be a potential source of } \\
\text { phosphates. }\end{array}$ \\
\hline $\begin{array}{l}\text { Concrete Materials Supplier } \\
\text { West Palm Beach, Florida }\end{array}$ & $\begin{array}{l}\text { No problems observed with deterioration of reinforced concrete structures } \\
\text { located in high phosphate-content soils in Florida. }\end{array}$ \\
\hline $\begin{array}{l}\text { Shaw Environmental, Inc. } \\
\text { Clermont, Florida }\end{array}$ & $\begin{array}{l}\text { Not observed any problems resulting from phosphate-ion deterioration of } \\
\text { reinforced concrete structures. }\end{array}$ \\
\hline $\begin{array}{l}\text { James Construction Group } \\
\text { Baton Rouge. Louisiana }\end{array}$ & $\begin{array}{l}\text { Not observed any problems resulting from phosphate-ion deterioration of } \\
\text { reinforced concrete structures. }\end{array}$ \\
\hline
\end{tabular}


Numerous contacts with cognizant research personnel and related industry organizations did not identify any apparent concerns or incidences of deterioration of reinforced concrete structures located in phosphate-rich locations. No special design requirements (e.g., increased cover, concrete mix proportions, or materials selection) were identified for concrete structures located in high-phosphate environments similar to that which exist for reinforced concrete structures in high sulfate or chloride environments. Finally, contacts with organizations involved with reinforced concrete structures located in high phosphate regions of Florida have not revealed any concerns or evidence of degradation of these structures due to exposure to phosphates contained in soils or ground water. 


\section{LABORATORY STUDY OF POTENTIAL FOR PHOSPHATE CORROSION OF ORDINARY PORTLAND CEMENTS}

Thermodynamic studies at ORNL and kinetic results presented in Chapter 2 were utilized to design and implement a "small-scale" laboratory study. The laboratory study was designed to investigate the effects of two aqueous phosphate systems representing different phosphate solubilities (i.e., $\mathrm{Na}_{2} \mathrm{HPO}_{4}$ and $\mathrm{MgHPO}_{4}$ ) on a Portland cement paste. The effect of the phosphate systems was assessed through comparisons of weight change, length change, and compressive strength results to those obtained from specimens exposed to a control environment [i.e., saturated $\mathrm{Ca}(\mathrm{OH})_{2}$ solution]. X-ray diffraction and scanning-electron microscope examinations were performed on materials obtained from representative specimens after being subjected for defined periods to each of the conditioning environments. The purpose of these supplemental examinations was to identify formation of any significant new phases or if the specimens show signs of degradation or secondary mineralization, phosphate minerals in particular.

\subsection{Experimental Program}

Type I-II Portland cement paste having a ratio of water to cement of $\sim 0.30$ was used to fabricate the test articles. Mixing was performed according to ASTM C305. ${ }^{61}$ Prismatic length-change (16 specimens) and cube specimens ( 48 specimens) were fabricated from the mix. The length change specimens were $1 \mathrm{x}$ 1 x 10 -in $(25.4 \times 25.4 \times 254.0-\mathrm{mm})$ prisms. Compressive strength specimens were 2 -inch $(50.8-\mathrm{mm})$ cubes. Figure 5.1 presents the prismatic and cube test specimens.

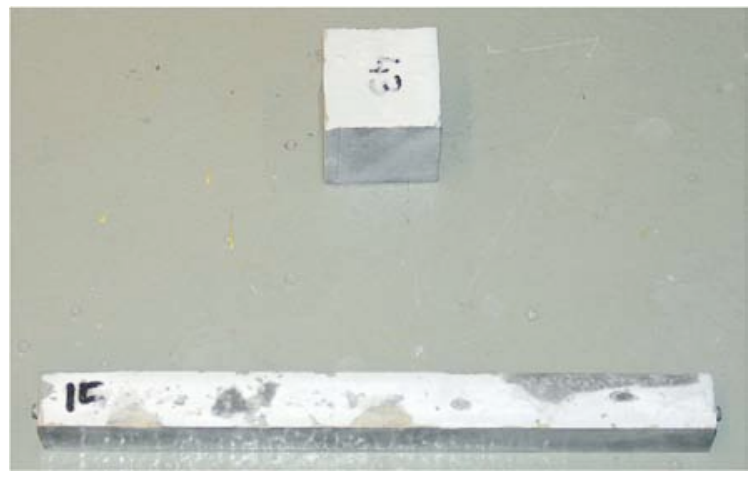

Figure 5.1 Prismatic and cube test specimens.

One-day after casting, the test articles were removed from their molds and cured under saturated conditions (100\% relative humidity) until exposure conditioning initiated. Conditioning of the test articles involved three exposure solutions: two concentrations of phosphate ions and a control solution. The phosphate solutions were selected to provide concentrations of phosphate ions much higher than normally experienced in service and included: (1) a saturated low-soluble phosphate salt, magnesium phosphate $\left(\mathrm{MgHPO}_{4}\right)$ and (2) a saturated high-solubility phosphate salt, sodium hydrogen phosphate dodecahydrate $\left(\mathrm{Na}_{2} \mathrm{HPO}_{4} * 12 \mathrm{H}_{2} \mathrm{O}\right)$. A saturated calcium hydroxide solution was utilized as the control for comparison of the phosphate results.

Excess solids of these salts were poured onto the bottom of plastic trays containing sufficient water that the cubes and prisms were completely submerged. The aqueous brine solutions became saturated in equilibrium with the excess solids. As a result, if the cement extracts phosphate from the brines, constant concentrations in the exposure brines are maintained during the concrete (cement paste) interaction with 
the brine. The test specimens were suspended above the excess solids on the bottom of the conditioning trays by using polyvinyl chloride (PVC) corner braces.

After predefined conditioning periods of 30-days, 3-months, 6-months, 1-year, and 18-months, specimens were removed from the conditioning solutions and tested. Tests performed after each of the conditioning periods included length change, weight change, and compressive strength. In addition, aliquots of representative materials were examined by scanning-electron microscope (SEM) and x-ray diffraction (XRD) techniques. Length change determinations and compressive strength tests were conducted in compliance with ASTM C157 $7^{62}$ and ASTM C109, ${ }^{63}$ respectively. Figures $5.2-5.4$ provide representations of test setups for length change, weight change, and compressive strength determination, respectively.

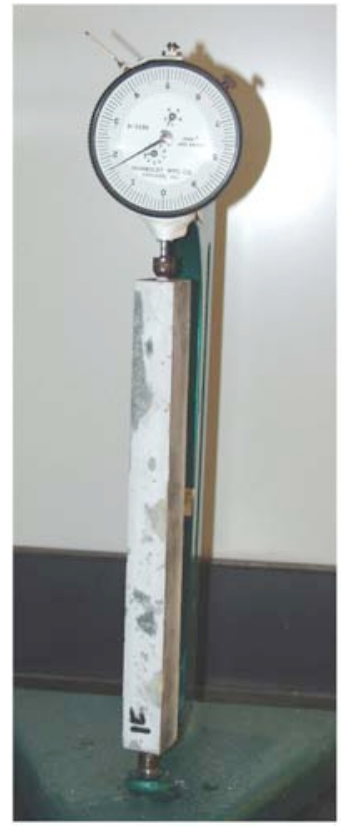

Figure 5.2 Length change test setup.

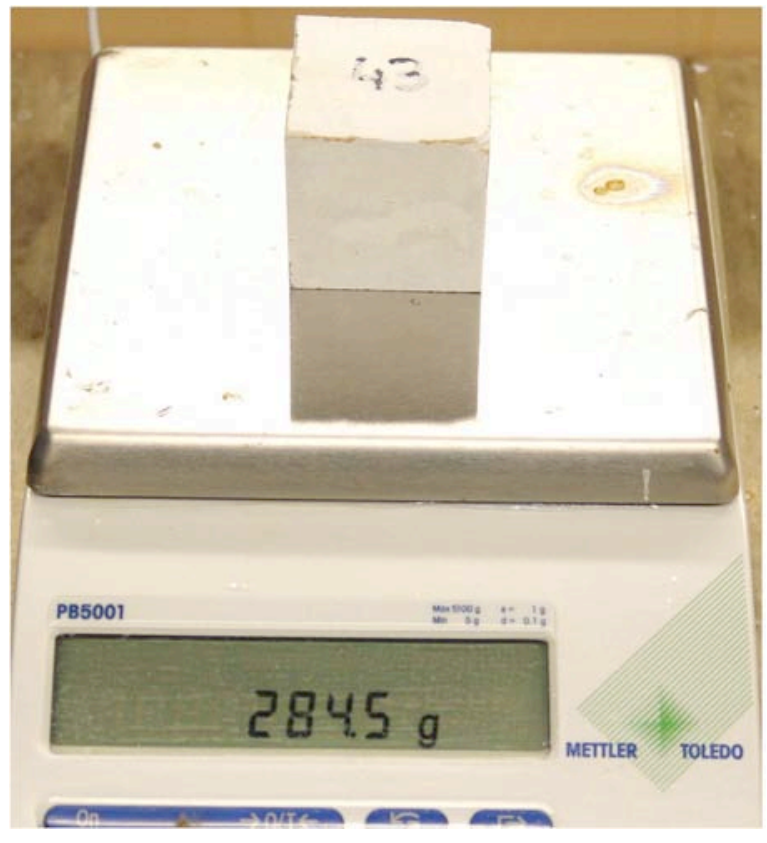

Figure 5.3 Specimen weight determination.

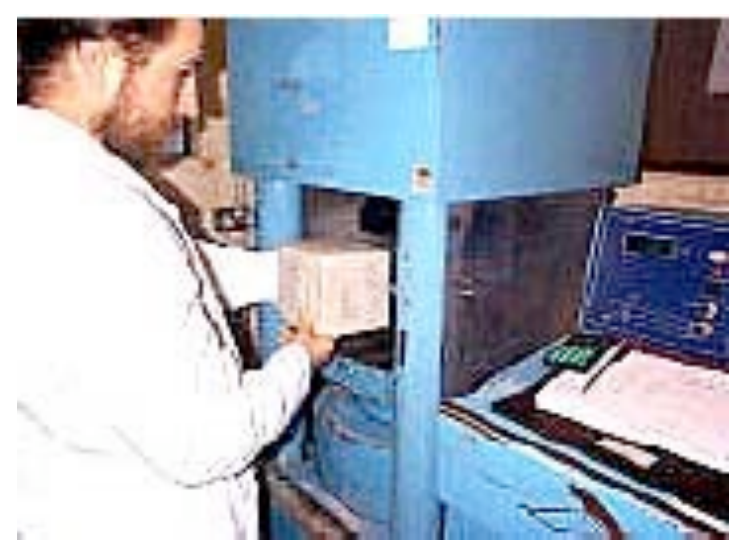

Figure 5.4 Representation of compressive strength test of cube test specimen. 


\subsection{Phosphate-Cement Interactions: One-Month Results}

Figure 5.5 presents the test setup for the exposure testing of the prismatic and cube test articles.

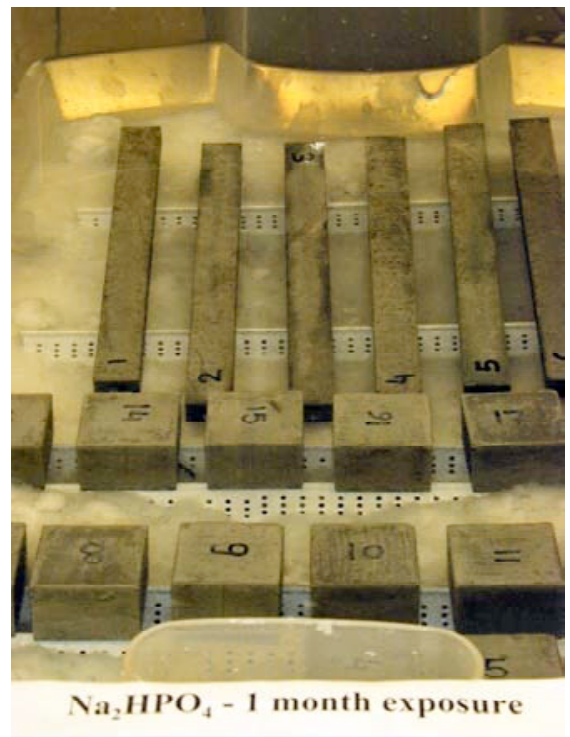

Figure 5.5 Exposure testing in saturated brines in which PVC corner braces are used to suspend cubes and prisms above the excess solids (visible).

As noted in Figure 5.6, after 1 month exposure the samples placed into the $\mathrm{Ca}(\mathrm{OH})_{2}$ solution exhibit no sign of crystal growth or alteration, as expected.

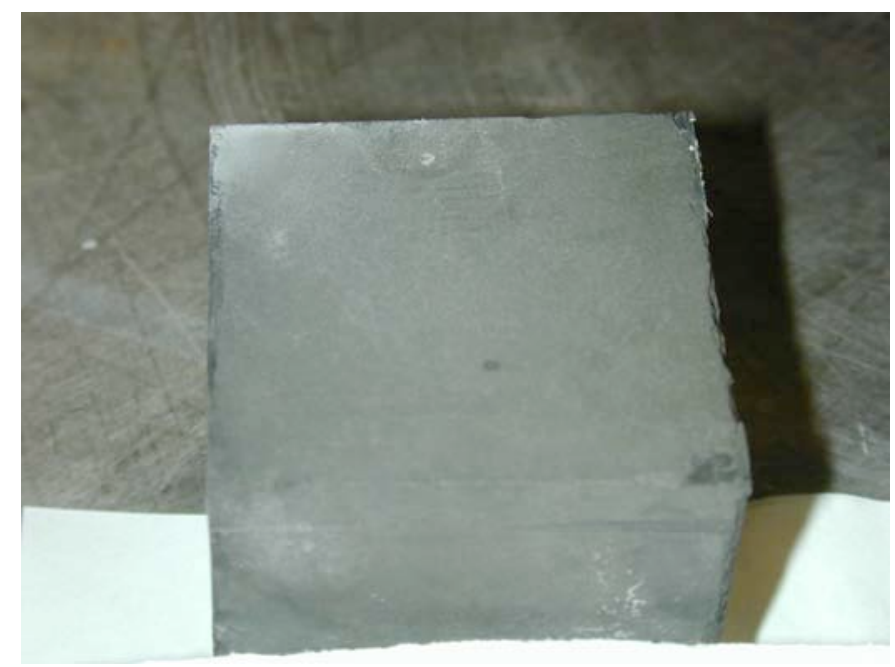

Figure 5.6 Cube specimen after 1 month in $\mathrm{Ca}(\mathrm{OH})_{2}$.

Figures 5.7 and 5.8, presents typical cube appearance after 1-month exposure in $\mathrm{MgHPO}_{4}$ and $\mathrm{Na}_{2} \mathrm{HPO}_{4}$ solutions, respectively. As noted in the figures, the phosphate solutions are beginning to show the formation of small crystal growth on the sides of the specimens. 


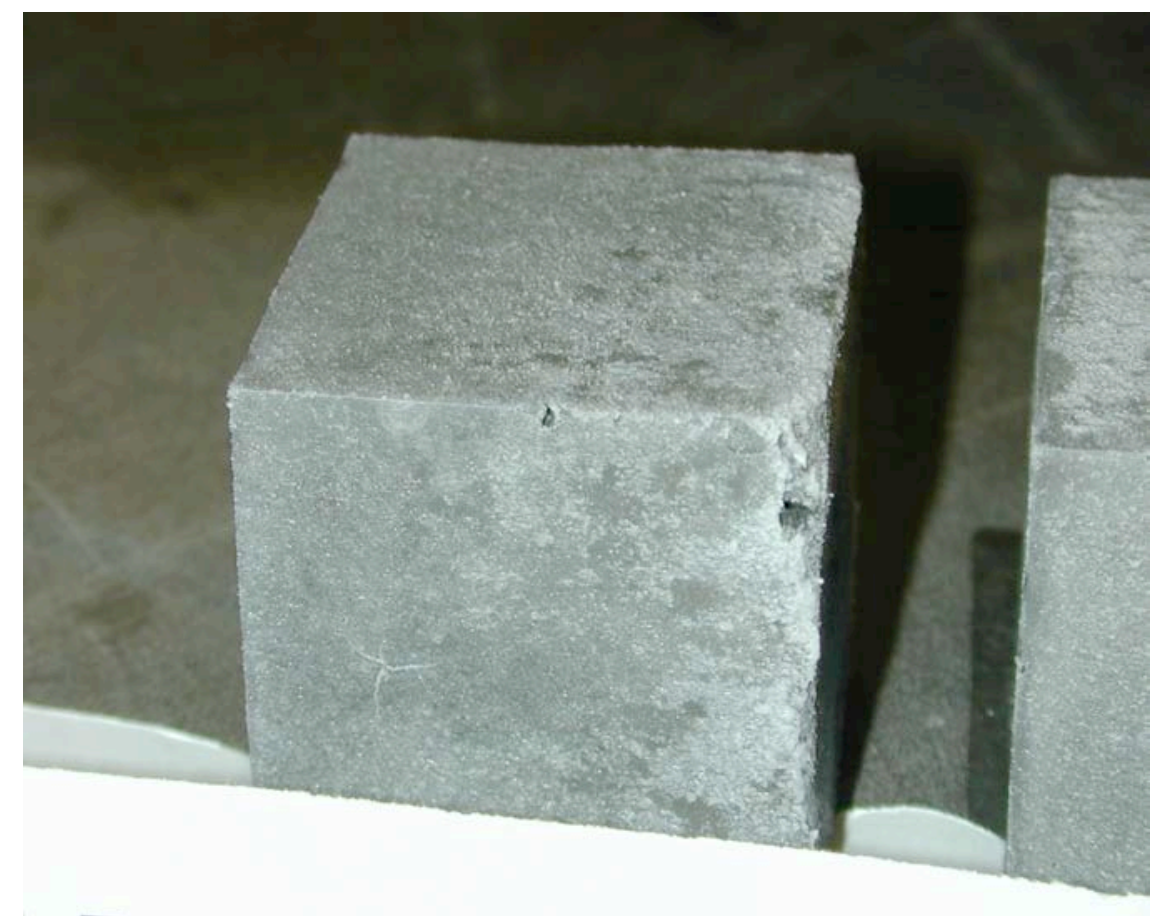

Figure 5.7 Cube specimen after 1 month in $\mathrm{MgHPO}_{4}$.

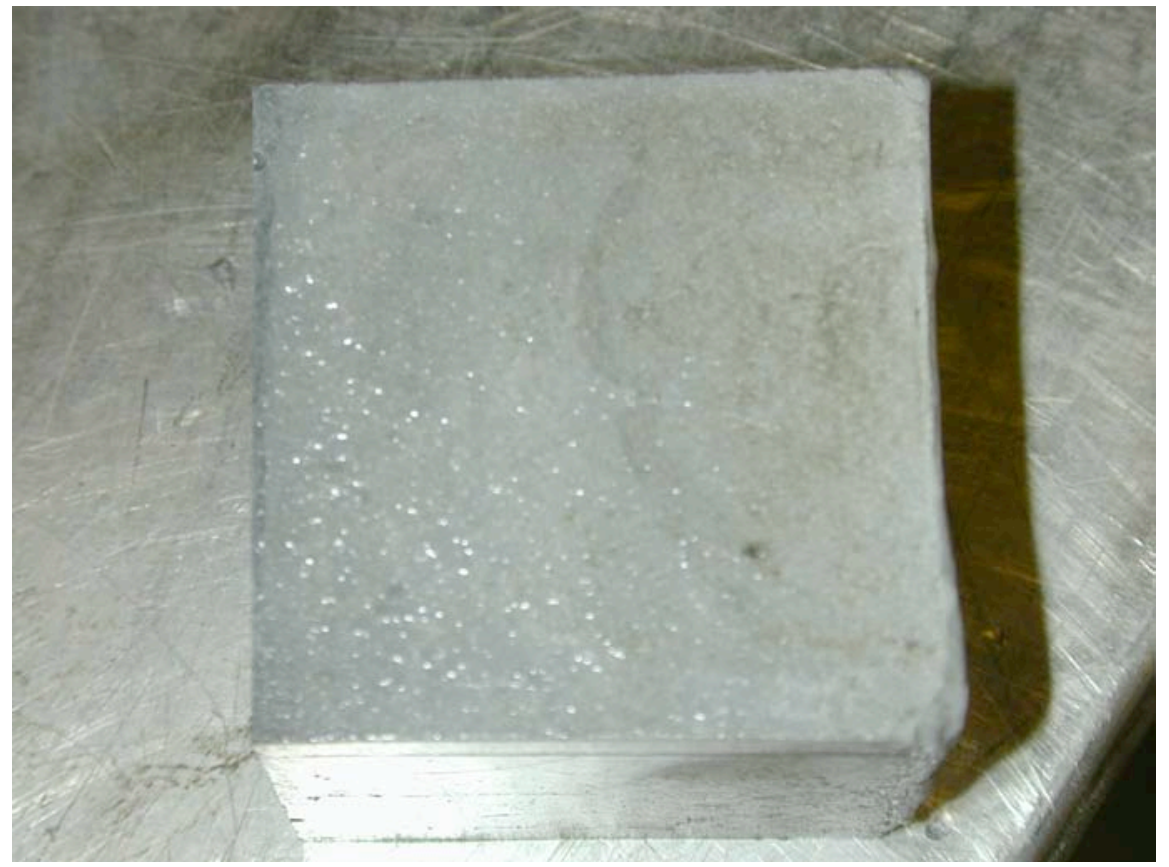

Figure 5.8 Cube specimen after 1 month in $\mathrm{Na}_{2} \mathrm{HPO}_{4}$.

Weight- and length-change results for specimens after one-month exposure to $\mathrm{Ca}(\mathrm{OH})_{2}$ (reference results), $\mathrm{Na}_{2} \mathrm{HPO}_{4}$, and $\mathrm{MgHPO}_{4}$ are summarized in Tables 5.1-5.3, respectively. 
Table 5.1 One-Month Weight- and Length-Change Results for Specimens Submerged in $\mathrm{Ca}(\mathrm{OH})_{2}$

\begin{tabular}{|c|c|c|c|c|c|c|c|}
\hline $\begin{array}{c}\text { Exposure } \\
\text { Time }\end{array}$ & Change & $\begin{array}{c}\mathrm{Ca}(\mathrm{OH})_{2} \\
\text { Sample } \\
1 \\
\end{array}$ & $\begin{array}{c}\mathrm{Ca}(\mathrm{OH})_{2} \\
\text { Sample } \\
2 \\
\end{array}$ & $\begin{array}{c}\mathrm{Ca}(\mathrm{OH})_{2} \\
\text { Sample } \\
3 \\
\end{array}$ & $\begin{array}{c}\mathrm{Ca}(\mathrm{OH})_{2} \\
\text { Sample } \\
4\end{array}$ & $\begin{array}{c}\mathrm{Ca}(\mathrm{OH})_{2} \\
\text { Sample } \\
5 \\
\end{array}$ & $\begin{array}{c}\mathrm{Ca}(\mathrm{OH})_{2} \\
\text { Sample } \\
6 \\
\end{array}$ \\
\hline \multirow[t]{6}{*}{1 month } & $\mathrm{Wt}(\mathrm{g})$ & 418.22 & 412.78 & 416.26 & 412.28 & 422 & 412.68 \\
\hline & $\Delta \mathrm{Wt}(\mathrm{g})$ & 6.67 & 9.79 & 9.64 & 8.96 & 6.23 & 10.27 \\
\hline & $\begin{array}{c}\Delta \mathrm{Wt} \\
(\%)\end{array}$ & 1.6 & 2.4 & 2.4 & 2.2 & 1.5 & 2.6 \\
\hline & Length & 1240 & 1179 & 1049 & 1120 & 1045 & 970 \\
\hline & $\Delta$ Length & 73 & 67 & 74 & 72 & 83 & 74 \\
\hline & $\begin{array}{c}\Delta \text { Length } \\
(\%)\end{array}$ & 6.3 & 6.0 & 7.6 & 6.9 & 8.6 & 8.3 \\
\hline
\end{tabular}

Table 5.2 One-Month Weight- and Length-Change Results for Specimens Submerged in $\mathrm{Na}_{2} \mathrm{HPO}_{4}$

\begin{tabular}{|c|c|c|c|c|c|c|c|c|}
\hline $\begin{array}{c}\text { Exposure } \\
\text { Time } \\
\end{array}$ & Change & $\begin{array}{c}\mathrm{Na}_{2} \mathrm{HPO}_{4} \\
\text { Sample } \\
1 \\
\end{array}$ & $\begin{array}{c}\mathrm{Na}_{2} \mathrm{HPO}_{4} \\
\text { Sample } \\
2 \\
\end{array}$ & $\begin{array}{c}\mathrm{Na}_{2} \mathrm{HPO}_{4} \\
\text { Sample } \\
3 \\
\end{array}$ & $\begin{array}{c}\mathrm{Na}_{2} \mathrm{HPO}_{4} \\
\text { Sample } \\
4 \\
\end{array}$ & $\begin{array}{c}\mathrm{Na}_{2} \mathrm{HPO}_{4} \\
\text { Sample } \\
5 \\
\end{array}$ & $\begin{array}{c}\mathrm{Na}_{2} \mathrm{HPO}_{4} \\
\text { Sample } \\
6 \\
\end{array}$ & $\begin{array}{c}\mathrm{Na}_{2} \mathrm{HPO}_{4} \\
\text { Sample } \\
7 \\
\end{array}$ \\
\hline \multirow[t]{6}{*}{1 month } & $\mathrm{Wt}(\mathrm{g})$ & 400.06 & 413.45 & 414.41 & 400.58 & 415.36 & 410.09 & 420.07 \\
\hline & $\begin{array}{l}\Delta \mathrm{Wt} \\
(\mathrm{g})\end{array}$ & 6.62 & 5.08 & 4.31 & 6.17 & 4.67 & 6.24 & 6.67 \\
\hline & $\begin{array}{l}\Delta \mathbf{W t} \\
(\%)\end{array}$ & 1.7 & 1.2 & 1.1 & 1.6 & 1.1 & 1.5 & 1.6 \\
\hline & length & 926 & 944 & 1062 & 1102 & 1214 & 1160 & 1109 \\
\hline & $\Delta$ length & 48 & 50 & 65 & 42 & 55 & 44 & 45 \\
\hline & $\begin{array}{c}\Delta \\
\text { Length } \\
(\%) \\
\end{array}$ & 5.5 & 5.6 & 6.5 & 4.0 & 4.7 & 3.9 & $\begin{array}{r}4.2 \\
\end{array}$ \\
\hline
\end{tabular}

Table 5.3 One-Month Weight- and Length-Change Results for Specimens Submerged in $\mathrm{MgHPO}_{4}$

\begin{tabular}{|c|c|c|c|c|c|c|c|c|c|}
\hline $\begin{array}{c}\text { Exposure } \\
\text { Time }\end{array}$ & Change & $\begin{array}{c}\text { MgHPO } \\
4 \\
\text { Sample } \\
1 \\
\end{array}$ & $\begin{array}{c}\mathrm{MgHPO}_{4} \\
\text { Sample } \\
2 \\
\end{array}$ & $\begin{array}{c}\mathrm{MgHPO}_{4} \\
\text { Sample } \\
3 \\
\end{array}$ & $\begin{array}{c}\mathrm{MgHPO}_{4} \\
\text { Sample } \\
4 \\
\end{array}$ & \begin{tabular}{c|} 
MgHPO \\
4 \\
Sample \\
5 \\
\end{tabular} & \begin{tabular}{c|} 
MgHPO \\
4 \\
Sample \\
6 \\
\end{tabular} & $\begin{array}{c}\mathrm{MgHPO}_{4} \\
\text { Sample } \\
7 \\
\end{array}$ & \\
\hline \multirow[t]{6}{*}{1 month } & $\mathrm{Wt}(\mathrm{g})$ & 408.18 & 418.16 & 416.92 & 414.58 & 405.06 & 408.71 & 409.68 & \multirow{5}{*}{$+1.7 \%$ avg. } \\
\hline & $\Delta \mathrm{Wt}(\mathrm{g})$ & 7.12 & 4.84 & 9.03 & 8.69 & 4.99 & 4.72 & 7.76 & \\
\hline & $\Delta \mathrm{Wt}(\%)$ & 1.8 & 1.2 & 2.2 & 2.1 & 1.2 & 1.2 & 1.9 & \\
\hline & Length & 1107 & 1158 & 955 & 969 & 1134 & 1049 & 1034 & \\
\hline & $\Delta$ Length & 69 & 77 & 70 & 165 & 67 & 81 & 71 & \\
\hline & $\begin{array}{c}\Delta \text { Length } \\
(\%)\end{array}$ & 6.6 & 7.1 & 7.9 & 20.5 & 6.3 & 8.4 & 7.4 & $\begin{array}{c}+7.3 \% \text { avg. } \\
\text { (excluding the } \\
\text { outlier) }\end{array}$ \\
\hline
\end{tabular}


After one month of exposure, a few crystals are seen growing on the samples kept in phosphate solutions; however, the change in length and weight of the specimens is not different from that measured for the control specimens $\left[\mathrm{Ca}(\mathrm{OH})_{2}\right]$.

\subsection{Phosphate-Cement Interactions: Three-Month Results}

\subsubsection{Weight Change, Length Change, and Compressive Strength Results}

After three-months exposure the samples kept in the $\mathrm{Ca}(\mathrm{OH})_{2}$ solution show no sign of crystal growth or alteration, as expected. The surface of the liquid is covered by a hard film of calcium carbonate that protects the samples underneath.

The samples kept in both of the phosphate solutions are exhibiting the formation of small crystal growth on the sides of the specimens. The crystals seen on the samples submerged in the magnesium phosphate solution appear to be somewhat larger than those observed on the samples submerged in the sodium phosphate solution.

Table 5.4-5.6 presents a comparison of one-month and three-month weight- and length-change results for samples submerged in the $\mathrm{Ca}(\mathrm{OH})_{2}$ (reference), $\mathrm{Na}_{2} \mathrm{HPO} 4$, and $\mathrm{MgHPO}_{4}$ solutions, respectively.

Table 5.4 One- and Three-Month Weight- and Length-Change Results for Specimens Submerged in $\mathrm{Ca}(\mathrm{OH})_{2}$

\begin{tabular}{|c|c|c|c|c|c|c|c|c|}
\hline \multicolumn{2}{|c|}{} & Sample & Sample & Sample & Sample & Sample & Sample & $\begin{array}{c}\text { Average } \\
\mathbf{C a}(\mathbf{O H})_{2}\end{array}$ \\
\hline \multirow{3}{*}{ 1 month } & $\Delta$ Wt (\%) & 1.6 & 2.4 & 2.4 & 2.2 & 1.5 & 2.6 & 2.1 \\
\cline { 2 - 9 } & $\Delta$ Length (\%) & 6.3 & 6.0 & 7.6 & 6.9 & 8.6 & 8.3 & 7.3 \\
\hline \multirow{3}{*}{3 months } & $\Delta$ Wt (\%) & 2.1 & 2.9 & 2.8 & 2.8 & 1.9 & 3.0 & 2.6 \\
\cline { 2 - 9 } & $\Delta$ Length (\%) & 8.7 & 7.7 & 10.1 & 9.4 & 11.7 & 11.4 & 9.8 \\
\hline
\end{tabular}

Table 5.5 One- and Three-Month Weight- and Length-Change Results for Specimens Submerged in $\mathrm{Na}_{2} \mathrm{HPO}_{4}$

\begin{tabular}{|c|c|c|c|c|c|c|c|c|c|}
\hline \multicolumn{2}{|c|}{} & Sample & Sample & Sample & Sample & Sample & Sample & Sample & $\begin{array}{c}\text { Average } \\
\mathbf{N a}_{2} \mathbf{H P O}_{4}\end{array}$ \\
\hline \multirow{3}{*}{ 1 month } & $\Delta$ Wt (\%) & 1.7 & 1.2 & 1.1 & 1.6 & 1.1 & 1.5 & 1.6 & 1.4 \\
\cline { 2 - 10 } & $\Delta$ Length (\%) & 5.5 & 5.6 & 6.5 & 4.0 & 4.7 & 3.9 & 4.2 & 4.9 \\
\hline \multirow{3}{*}{3 months } & $\Delta$ Wt (\%) & 2.4 & 1.8 & 1.5 & 2.3 & 1.6 & 2.2 & 2.3 & 2.0 \\
\cline { 2 - 9 } & $\Delta$ Length (\%) & 7.9 & 7.8 & 8.1 & 5.6 & 7.1 & 5.9 & 6.0 & 6.9 \\
\hline
\end{tabular}


Table 5.6 One- and Three-Month Weight- and Length-Change Results for Specimens Submerged in $\mathrm{MgHPO}_{4}$

\begin{tabular}{|c|c|c|c|c|c|c|c|c|c|}
\hline \multicolumn{2}{|c|}{} & $\begin{array}{c}\text { Sample } \\
\mathbf{1}\end{array}$ & $\begin{array}{c}\text { Sample } \\
\mathbf{2}\end{array}$ & $\begin{array}{c}\text { Sample } \\
\mathbf{3}\end{array}$ & $\begin{array}{c}\text { Sample } \\
\mathbf{4}\end{array}$ & $\begin{array}{c}\text { Sample } \\
\mathbf{5}\end{array}$ & $\begin{array}{c}\text { Sample } \\
\mathbf{6}\end{array}$ & $\begin{array}{c}\text { Sample } \\
\mathbf{7}\end{array}$ & $\begin{array}{c}\text { Average } \\
\text { MgHPO }_{\mathbf{4}}\end{array}$ \\
\hline \multirow{3}{*}{ 1 month } & $\Delta \mathrm{Wt}(\%)$ & 1.8 & 1.2 & 2.2 & 2.1 & 1.2 & 1.2 & 1.9 & 1.7 \\
\cline { 2 - 10 } & $\Delta$ Length (\%) & 6.6 & 7.1 & 7.9 & 7.2 & 6.3 & 8.4 & 7.4 & 7.3 \\
\hline \multirow{3}{*}{3 months } & $\Delta$ Wt (\%) & 2.4 & 1.7 & 2.7 & 2.6 & 1.8 & 1.6 & 2.5 & 2.2 \\
\cline { 2 - 9 } & $\Delta$ Length (\%) & 9.1 & 9.4 & 11.4 & 10.6 & 8.9 & 11.8 & 10.1 & 10.2 \\
\hline
\end{tabular}

Figures 5.9, 5.10, and 5.11 present one- and three-month unconfined compressive strength results for specimens submerged in $\mathrm{Ca}(\mathrm{OH})_{2}$ (control), $\mathrm{Na}_{2} \mathrm{HPO}_{4}$, and $\mathrm{MgHPO}_{4}$ solutions, respectively.

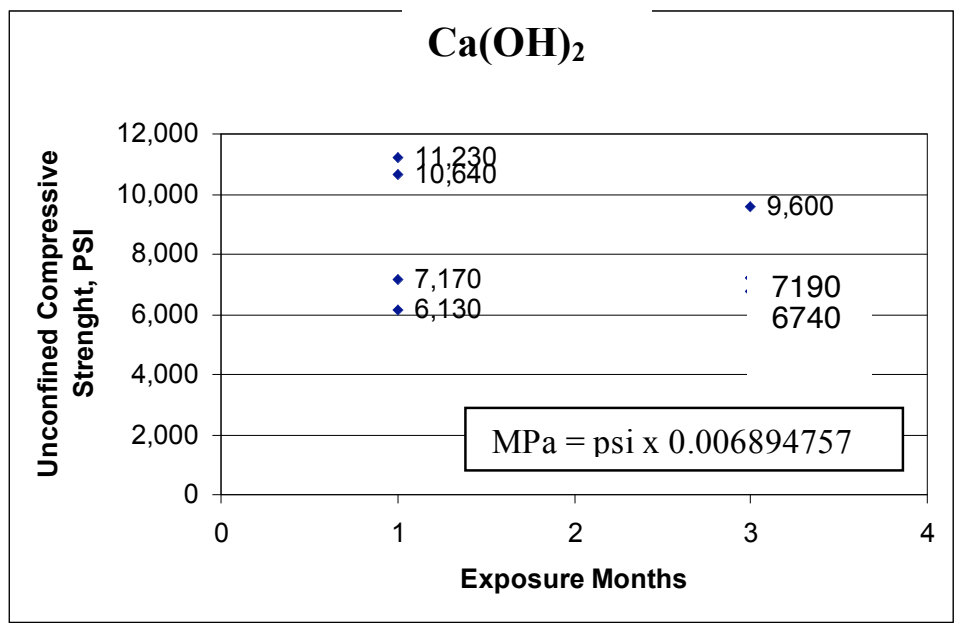

Figure 5.9 Unconfined compressive strength after one- and three-month exposure of test specimens in $\mathrm{Ca}(\mathrm{OH})_{2}$.

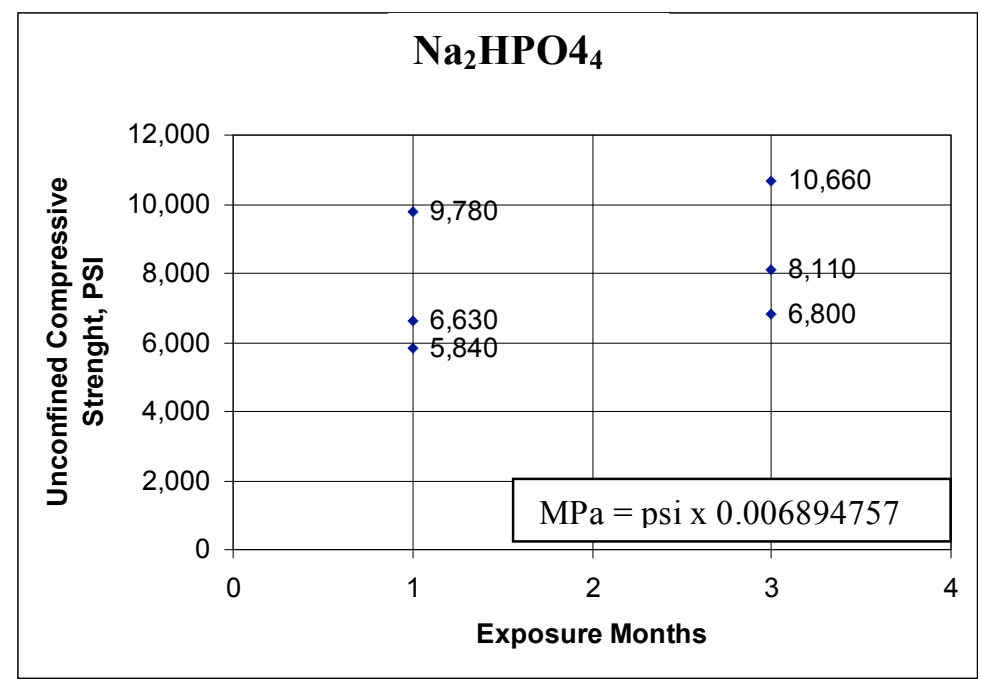

Figure 5.10 Unconfined compressive strength after one- and three-month exposure of test specimens in $\mathrm{Na}_{2} \mathrm{HPO}_{4}$. 


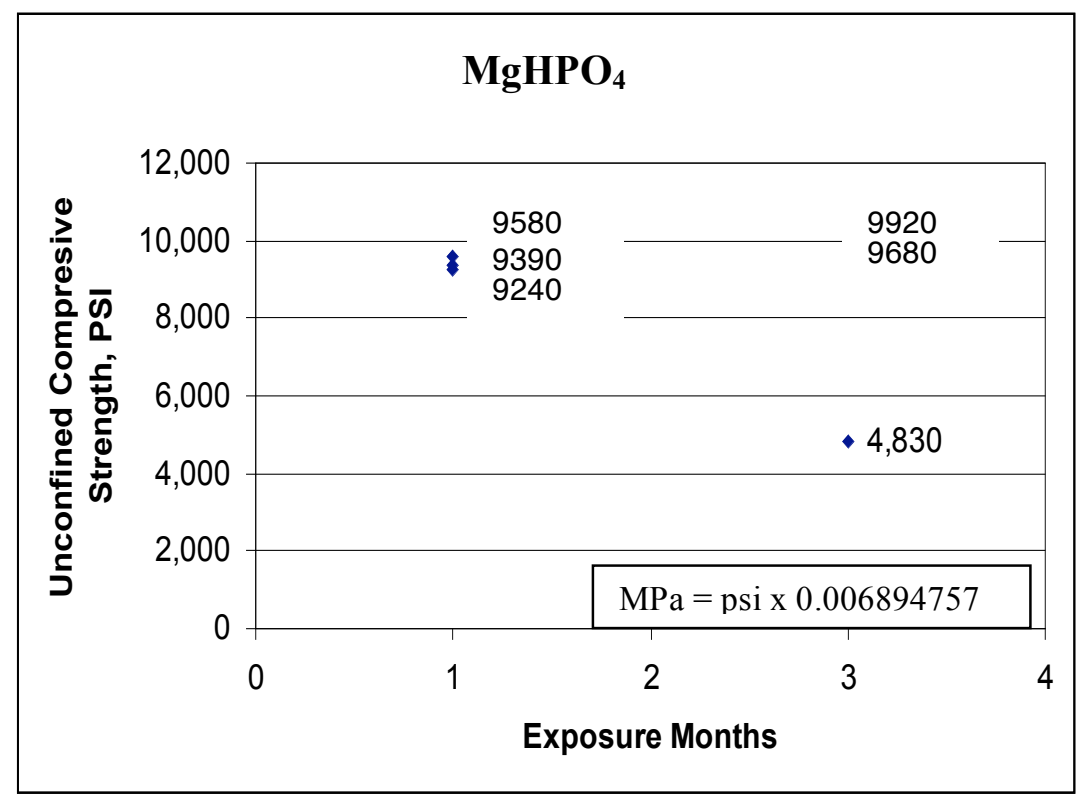

Figure 5.11 Unconfined compressive strength after one- and three-month exposure of test specimens in $\mathrm{MgHPO}_{4}$.

After three-months exposures, there does not appear to be a significant difference between the unconfined compressive strengths of the specimens cured in the phosphate solutions and the control specimens cured in a $\mathrm{Ca}(\mathrm{OH})_{2}$ solution.

\subsubsection{Mineralogic Evolution of the Samples During Curing}

ICP analyses of the curing solutions

The curing solutions have been sampled and analyzed by Inductively Coupled Plasma (ICP) - Atomic Emission Spectroscopy. Samples were taken just prior to introducing the cement paste specimens into the solutions and after removing samples for testing after exposures of one and three months. The ICP analyses are presented in Tables 5.7 to 5.9.

Table 5.7 Analysis of the $\mathrm{Ca}(\mathrm{OH})_{2}$ Curing Solution (Results in mg/L)

\begin{tabular}{|c|c|c|c|c|c|c|c|c|c|c|c|c|}
\hline \multirow[b]{2}{*}{ Aluminum } & \multicolumn{4}{|c|}{ Initial - 3/01/05 } & \multicolumn{4}{|c|}{28 days cure $-3 / 29 / 05$} & \multicolumn{4}{|c|}{3 months cure $-6 / 08 / 05$} \\
\hline & $<$ & 0.6 & $+/-$ & 0.2 & $<$ & 0.6 & $+/-$ & 0.2 & $<$ & 1.2 & $+/-$ & 0.8 \\
\hline Barium & & 0.05 & $+/-$ & 0.00 & & 0.40 & $+/-$ & 0.01 & & 0.40 & $+/-$ & 0.04 \\
\hline Calcium & & 746 & $+/-$ & 10 & & 715 & $+/-$ & 22 & & 744 & $+/-$ & 60 \\
\hline Cadmium & & 0.03 & $+/-$ & 0.00 & & 0.03 & $+/-$ & 0.00 & $<$ & 0.02 & $+/-$ & 0.01 \\
\hline Iron & $<$ & 0.9 & $+/-$ & 0.2 & $<$ & 0.9 & $+/-$ & 0.5 & $<$ & 1.8 & $+/-$ & 1.0 \\
\hline Potassium & & 1.5 & $+/-$ & 0.1 & & 78 & $+/-$ & 2 & & 115 & $+/-$ & 9 \\
\hline Sodium & & 5.4 & $+/-$ & 0.1 & & 28.1 & $+/-$ & 0.7 & & 40.4 & $+/-$ & 3.3 \\
\hline Silicon & $<$ & 0.3 & $+/-$ & 0.1 & $<$ & 0.3 & $+/-$ & 0.1 & $<$ & 0.5 & $+/-$ & 0.3 \\
\hline Strontium & & 0.41 & $+/-$ & 0.00 & & 1.62 & $+/-$ & 0.04 & & 1.7 & $+/-$ & 0.1 \\
\hline
\end{tabular}


Table 5.8 Analysis of the $\mathrm{MgHPO}_{4}$ Curing Solution (Results in $\mathrm{mg} / \mathrm{L}$ )

\begin{tabular}{|c|c|c|c|c|c|c|c|c|c|c|c|c|}
\hline & & \multicolumn{3}{|c|}{ Initial - 3/01/05 } & \multicolumn{4}{|c|}{28 days cure $-3 / 29 / 05$} & \multicolumn{4}{|c|}{3 months cure $-6 / 08 / 05$} \\
\hline Aluminum & $<$ & 0.6 & $+/-$ & 0.1 & $<$ & 0.6 & $+/-$ & 0.2 & $<$ & 1.2 & $+/-$ & 0.2 \\
\hline Barium & & 0.02 & $+/-$ & 0.00 & & 0.02 & $+/-$ & 0.00 & $<$ & 0.02 & $+/-$ & 0.00 \\
\hline Calcium & & 14.8 & $+/-$ & 0.4 & & 5.2 & $+/-$ & 0.2 & $<$ & 2.6 & $+/-$ & 0.9 \\
\hline Cadmium & & 0.03 & $+/-$ & 0.00 & & 0.03 & $+/-$ & 0.01 & $<$ & 0.02 & $+/-$ & 0.01 \\
\hline Iron & $<$ & 0.9 & $+/-$ & 0.7 & $<$ & 0.9 & $+/-$ & 0.2 & $<$ & 1.8 & $+/-$ & 0.3 \\
\hline Potassium & & 1.3 & $+/-$ & 0.2 & & 92 & $+/-$ & 5 & & 153 & $+/-$ & 15 \\
\hline Magnesium & & 67 & $+/-$ & 2 & & 0.4 & $+/-$ & 0.1 & & 28.4 & $+/-$ & 3.7 \\
\hline Sodium & & 5.7 & $+/-$ & 0.2 & & 35 & $+/-$ & 1 & & 62 & $+/-$ & 7 \\
\hline Silicon & & 1.7 & $+/-$ & 0.1 & & 19.3 & $+/-$ & 1.1 & & 22.3 & $+/-$ & 2.8 \\
\hline Strontium & & 0.03 & $+/-$ & 0.00 & & 0.01 & $+/-$ & 0.00 & $<$ & 0.02 & $+/-$ & 0.00 \\
\hline
\end{tabular}

Table 5.9 Analysis of the $\mathrm{Na}_{2} \mathrm{HPO}_{4}$ Curing Solution (Results in mg/L)

\begin{tabular}{|c|c|c|c|c|c|c|c|c|c|c|c|c|}
\hline & \multicolumn{4}{|c|}{ Initial - 3/01/05 } & \multicolumn{4}{|c|}{28 days cure $-3 / 29 / 05$} & \multicolumn{4}{|c|}{3 months cure $-6 / 08 / 05$} \\
\hline Aluminum & $<$ & 6.0 & $+/-$ & 4.5 & & 25 & $+/-$ & 18 & $<$ & 1.2 & $+/-$ & 0.2 \\
\hline Barium & & 0.18 & $+/-$ & 0.02 & & 0.14 & $+/-$ & 0.01 & $<$ & 0.02 & $+/-$ & 0.01 \\
\hline Calcium & $<$ & 13 & $+/-$ & 1 & $<$ & 13 & $+/-$ & 6 & $<$ & 2.6 & $+/-$ & 0.1 \\
\hline Cadmium & & 0.39 & $+/-$ & 0.08 & & 0.37 & $+/-$ & 0.06 & & 0.03 & $+/-$ & 0.01 \\
\hline Chromium & & 0.51 & $+/-$ & 0.11 & & 0.59 & $+/-$ & 0.01 & & 0.69 & $+/-$ & 0.04 \\
\hline Potassium & & 23 & $+/-$ & 4 & & 129 & $+/-$ & 5 & & 315 & $+/-$ & 11 \\
\hline Magnesium & & 11 & $+/-$ & 3 & & 16 & $+/-$ & 6 & & 6.8 & $+/-$ & 0.2 \\
\hline Sodium & & 19978 & $+/-$ & 1160 & & 24131 & $+/-$ & 819 & & 28235 & $+/-$ & 999 \\
\hline Silicon & $<$ & 2.5 & $+/-$ & 1.7 & & 3.3 & $+/-$ & 0.3 & & 5.4 & $+/-$ & 0.2 \\
\hline Strontium & & 0.11 & $+/-$ & 0.01 & $<$ & 0.10 & $+/-$ & 0.01 & $<$ & 0.02 & $+/-$ & 0.00 \\
\hline
\end{tabular}

\section{$X$-ray diffraction results}

Pieces of the crushed samples after 3 months of cure were analyzed by x-ray diffraction (XRD) to identify the minerals present. Each sample was first dried for 4 days in an oven at $80^{\circ} \mathrm{C}$ to remove the nonreacted water to stop further reactions. An aliquot of each sample was then crushed and sieved to obtain material passing a $75 \mu \mathrm{m}$ sieve. X-ray diffraction examinations of the material were performed using a Scintag PADV vertical theta/2-theta goniometer available at the ORNL High Temperature Materials Laboratory (HTML). This instrument coupled with the Jade ${ }^{\circledR}$ software permits phase identification by means of computer search-match using the entire Powder Diffraction File. Spectra were run from the external zone of the sample and from the center of the sample and then compared to see if there was any effect from the solutions on the formation of the hydrated phases near the outside boundary of the specimens. It appeared that no difference was visible in the nature of the phases observed.

Samples cured in $\mathrm{Ca}(\mathrm{OH})_{2}$. XRD spectra of an aliquot of the sample cured in $\mathrm{Ca}(\mathrm{OH})_{2}$ are presented in Figure 5.12. The minerals identified are those usually found in a normal neat cement paste. The hydrated phases are Portlandite $\left(\mathrm{Ca}(\mathrm{OH})_{2}\right)$, Ettringite $\left(3 \mathrm{CaO} \bullet \mathrm{Al}_{2} \mathrm{O}_{3} \cdot 3 \mathrm{CaSO}_{4} \cdot 32 \mathrm{H}_{2} \mathrm{O}\right)$, calcium silicate hydrate $(\mathrm{C}$ $\mathrm{S}-\mathrm{H})$, and some possible calco-aluminum hydrates containing some sulfate. Peaks from nonreacted anhydrous constituents of the cement were also identified - tricalcium silicate $\left(3 \mathrm{CaO} \cdot \mathrm{SiO}_{2}\right)$, dicalcium silicate $\left(2 \mathrm{CaO} \cdot \mathrm{SiO}_{2}\right)$ and, Brownmillerite $\left(4 \mathrm{CaO} \cdot \mathrm{Al}_{2} \mathrm{O}_{3} \cdot \mathrm{Fe}_{2} \mathrm{O}_{3}\right)$. The samples were not protected from the $\mathrm{CO}_{2}$ atmosphere so the presence of Calcite $\left(\mathrm{CaCO}_{3}\right)$ was also observed. This spectrum is the reference standard for the samples cured in the phosphate solutions. 


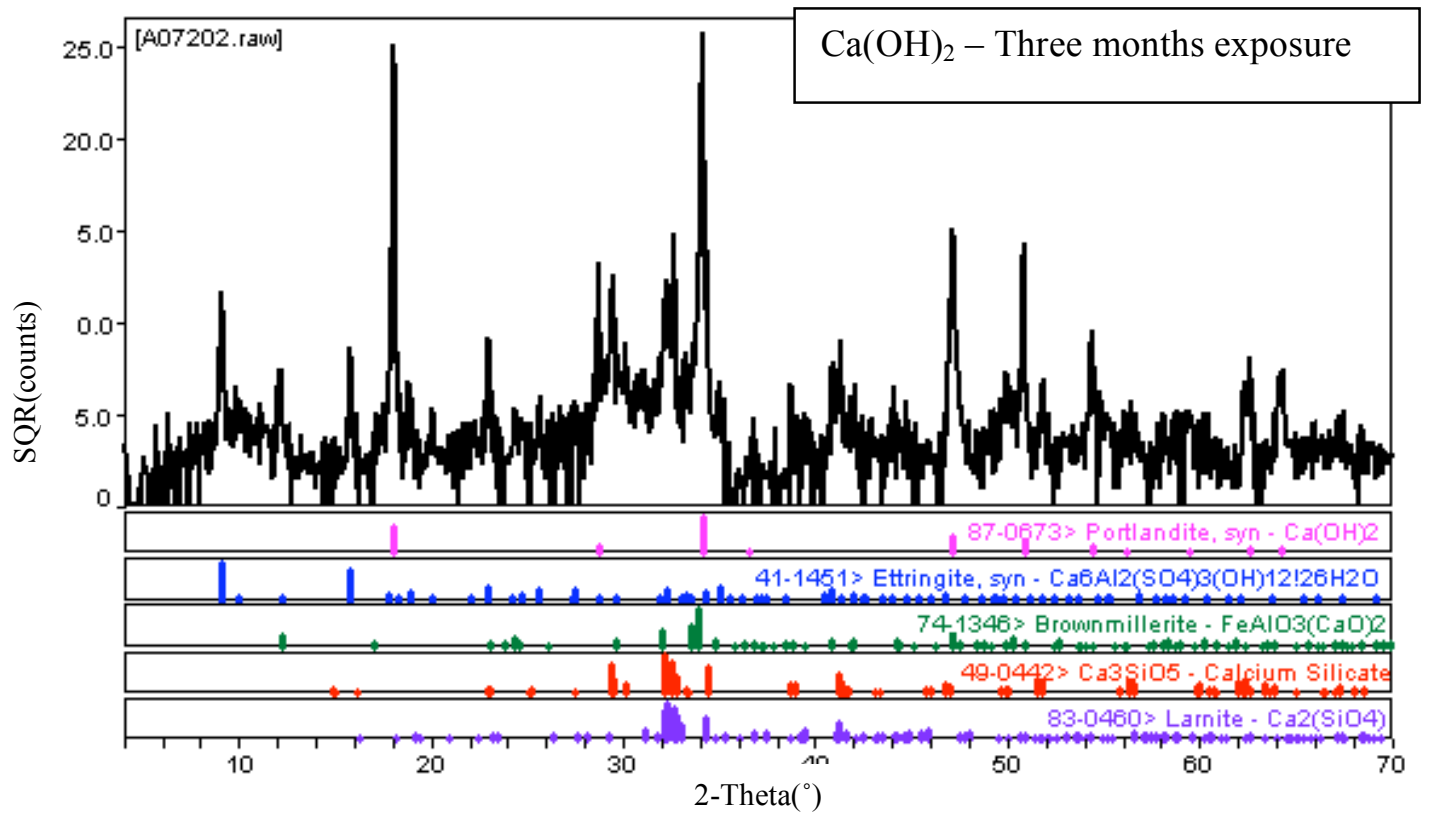

Figure 5.12 XRD spectrum of sample cured in $\mathrm{Ca}(\mathrm{OH})_{2}$ for three months.

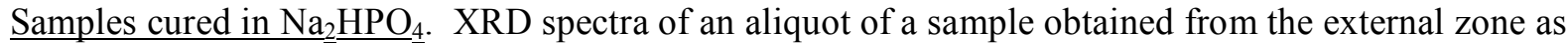
well as the center of the cement paste cube cured in $\mathrm{Na}_{2} \mathrm{HPO}_{4}$ are presented in Figures 5.13 and 5.14.

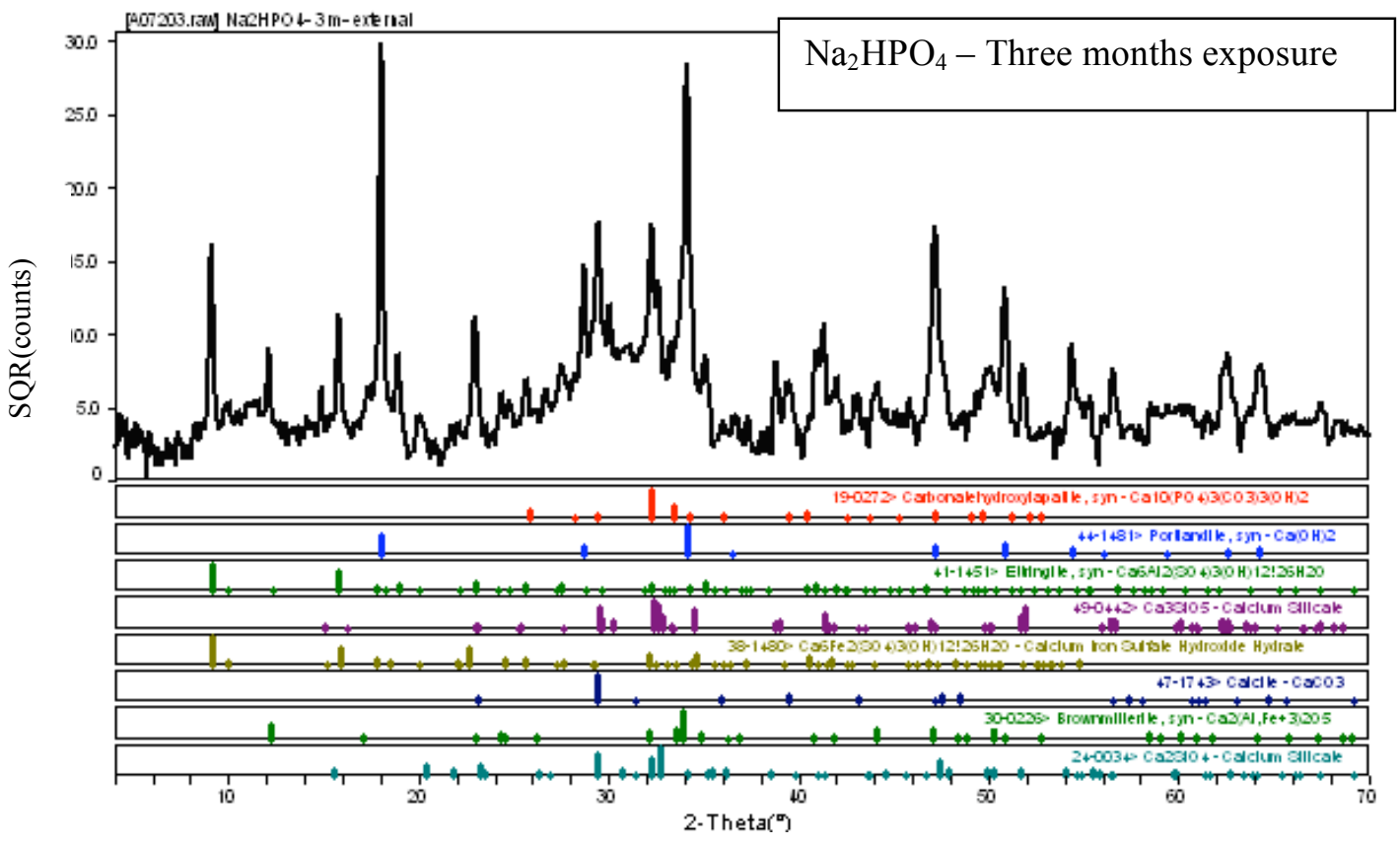

Figure 5.13 XRD spectrum of the external zone of sample cured in $\mathrm{Na}_{2} \mathrm{HPO}_{4}$ for three months. 


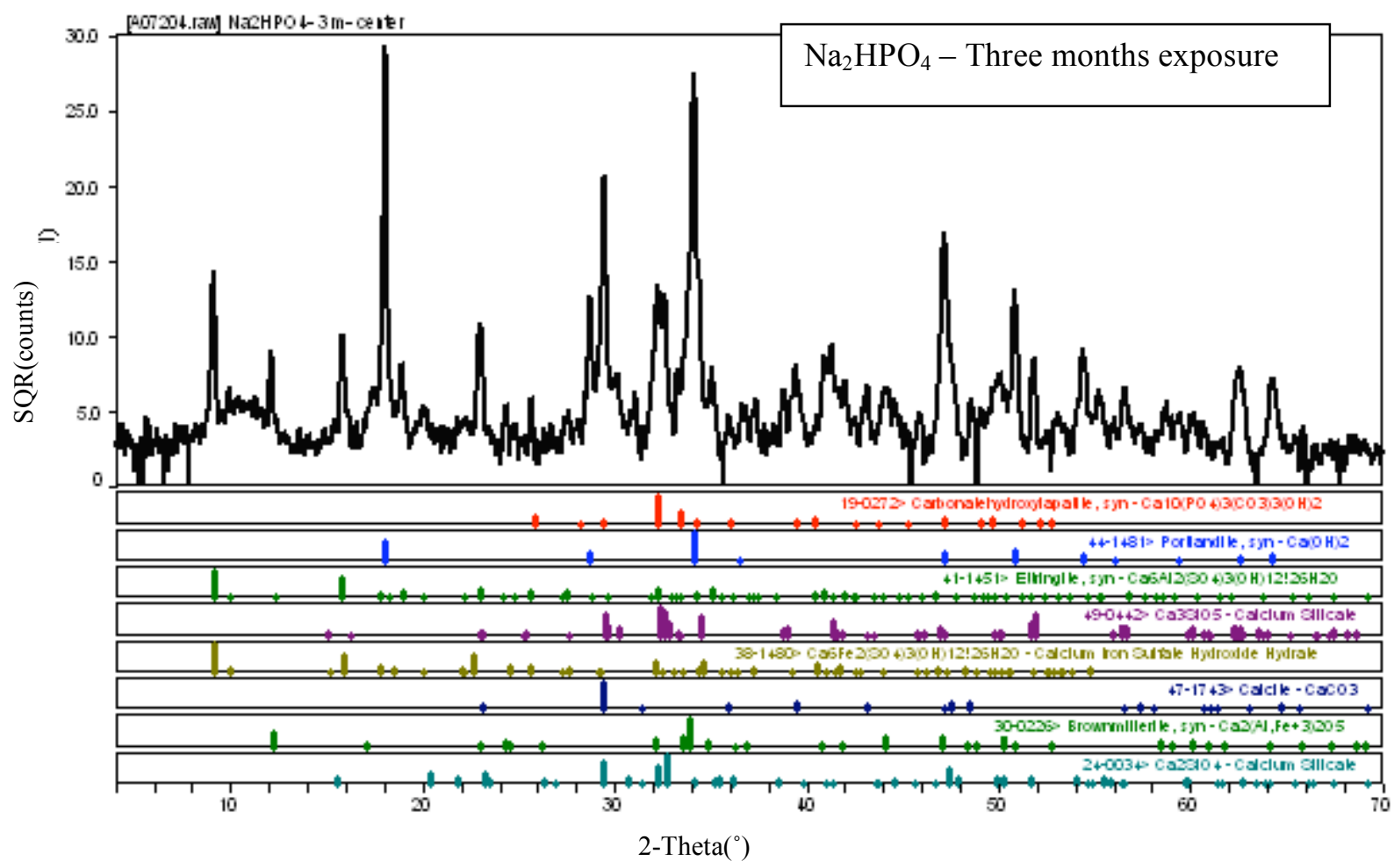

Figure 5.14 XRD spectrum of the internal zone of sample cured in $\mathrm{Na}_{2} \mathrm{HPO}_{4}$ for three months.

The spectra from the external and internal zone are similar with respect to the peaks present. The only difference is in the presence of a more pronounced halo of amorphous compounds that is seen between 26 and 34 degrees in 2-theta angle in the external zone relative to the internal zone. The samples cured in the solution of $\mathrm{Na}_{2} \mathrm{HPO}_{4}$ are not very different from those cured in the standard $\mathrm{Ca}(\mathrm{OH})_{2}$ solution as can be seen in comparing Figures 5.12 and 5.13. A possible match for hydroxylapatite carbonated $\mathrm{Ca}_{10}\left(\mathrm{PO}_{4}\right)_{3}\left(\mathrm{CO}_{3}\right)_{3}(\mathrm{OH})_{2}$ was found; however, due to the complexity of the sprectrum, a formal identification was not possible.

Samples cured in $\mathrm{MgHPO}_{4}$. XRD spectra of an aliquot of a sample obtained from the external zone as well as the center of the cement paste cube cured in $\mathrm{MgHPO}_{4}$ are presented in Figures 5.15 and 5.16.

For these samples there also was no difference between the outside of the cube that was in contact with the solution and the center of the cube. The same hydrates and anhydrous compounds are found in this sample as observed in the other two. Two patterns for phosphate compounds are presented in Fig. 5.16, but the presence of these phases is not likely to be confirmed. 


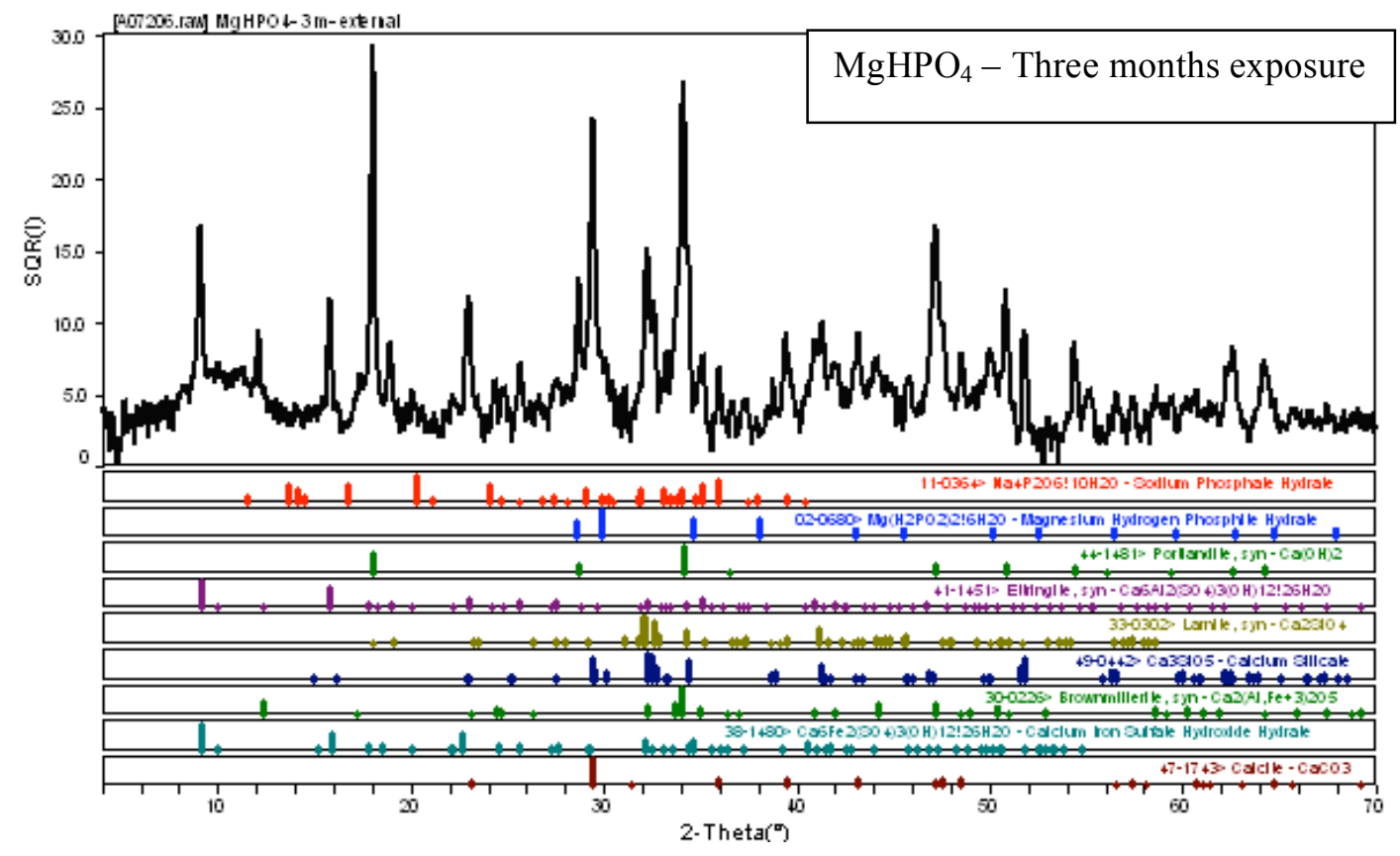

Figure 5.15 XRD spectrum of the external zone of the sample cured in $\mathrm{MgHPO}_{4}$ for 3 months.

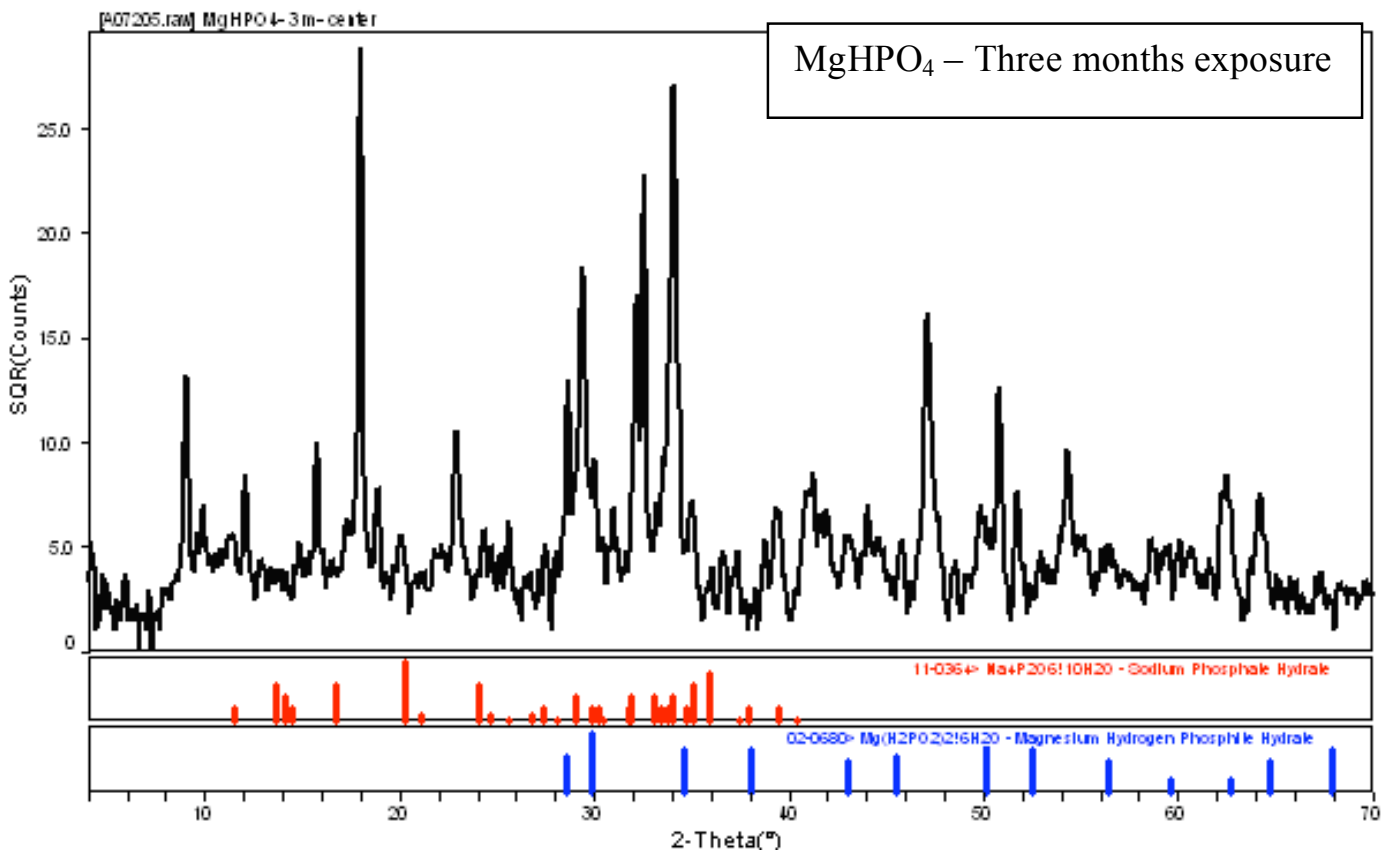

Figure 5.16 XRD spectrum of the internal zone of the sample cured in $\mathrm{MgHPO}_{4}$ for 3 months. 
XRD Conclusions after three-months exposure. The XRD analyses performed on the samples cured for three months does not reveal with any certainty the presence of mineral compounds containing phosphate. The mineralogical phases identified are those of a neat cement paste.

\section{SEM examination of the samples cured for three months}

The formation of new mineralogical compounds such as hydroxyapatite would likely be localized near the border of the cement paste specimen where it is in contact with the phosphate solution. Samples were prepared for SEM examination to observe a fresh fracture going from the outside border to the center of the cement paste specimen. The examination of the internal zone of the specimens showed the presence of the minerals identified by XRD. Figures 5.17 to 5.20 present SEM results.

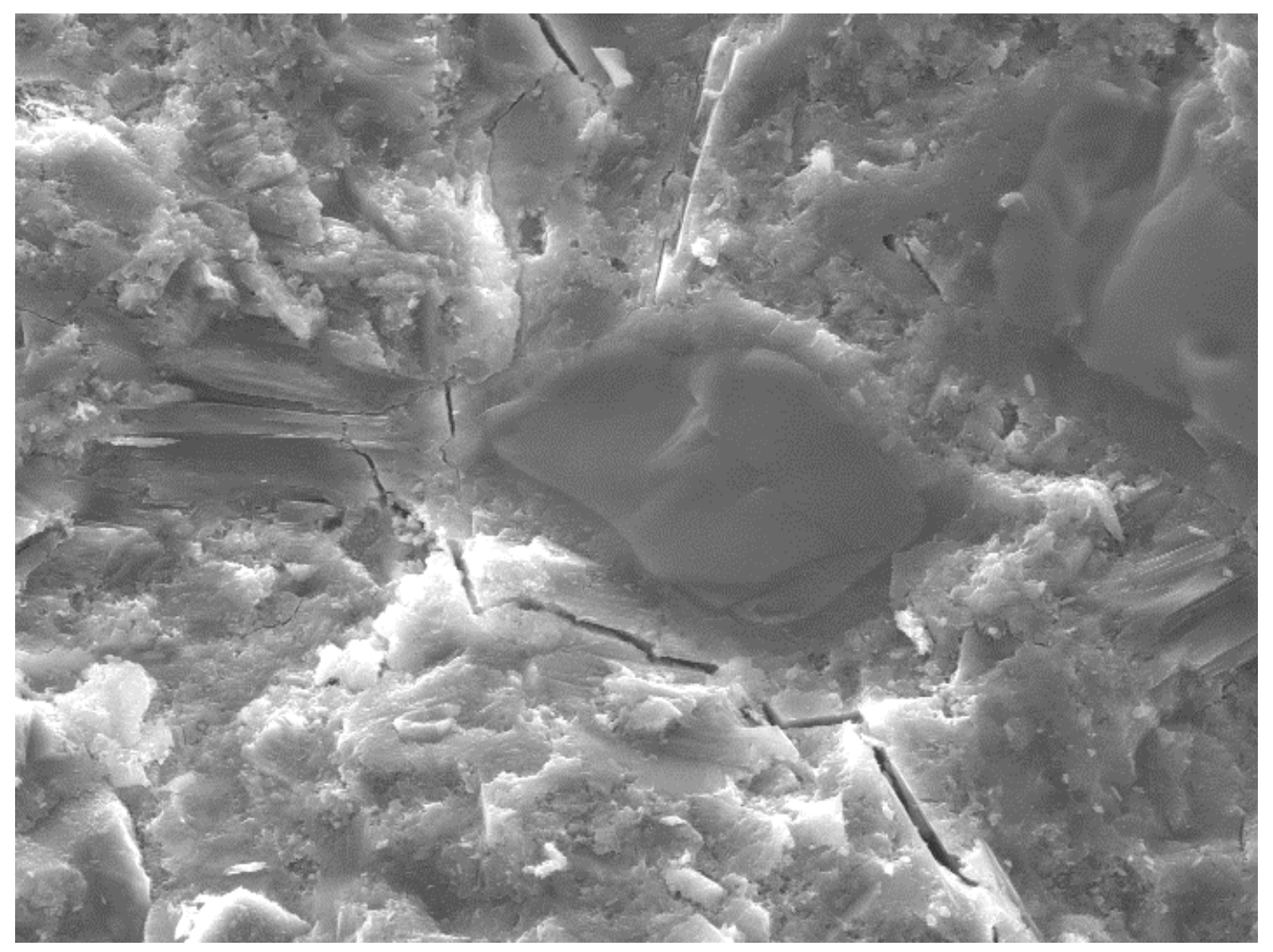

Figure 5.17 SEM of sample cured in $\mathrm{Na}_{2} \mathrm{HPO}_{4}$. In the center, a crystal of $\mathrm{C}_{3} \mathrm{~S}$ is surrounded by a layer of C-S-H. $\mathrm{Ca}(\mathrm{OH})_{2}$ crystals are mixed within the C-S-H of the paste (X 2000). 


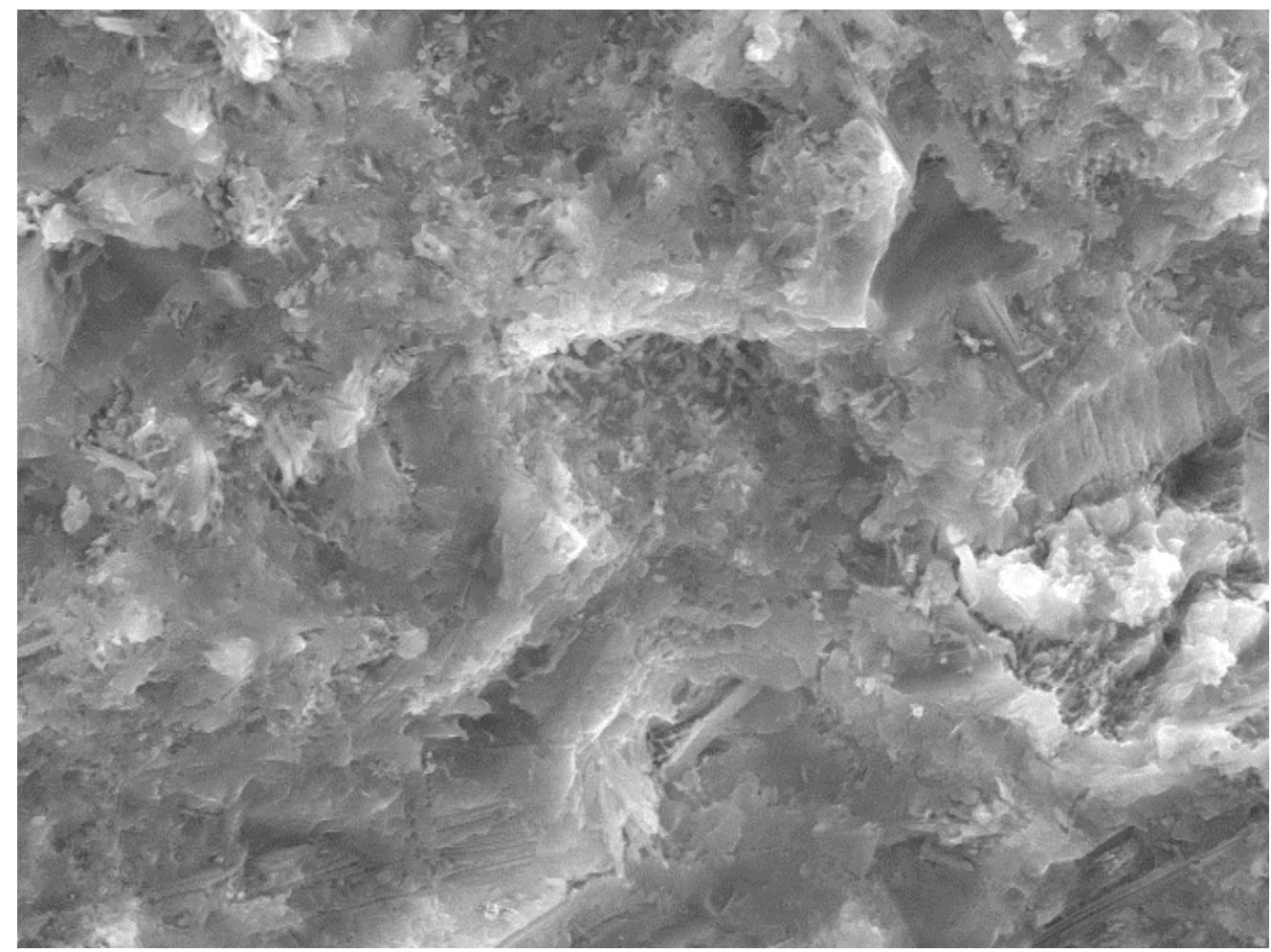

Figure 5.18 $\mathrm{SEM}$ of sample cured in $\mathrm{MgHPO}_{4}$ solution for three months. The paste contains C-S-H, $\mathrm{Ca}(\mathrm{OH})_{2}$ and ettringite crystals (X 4000).

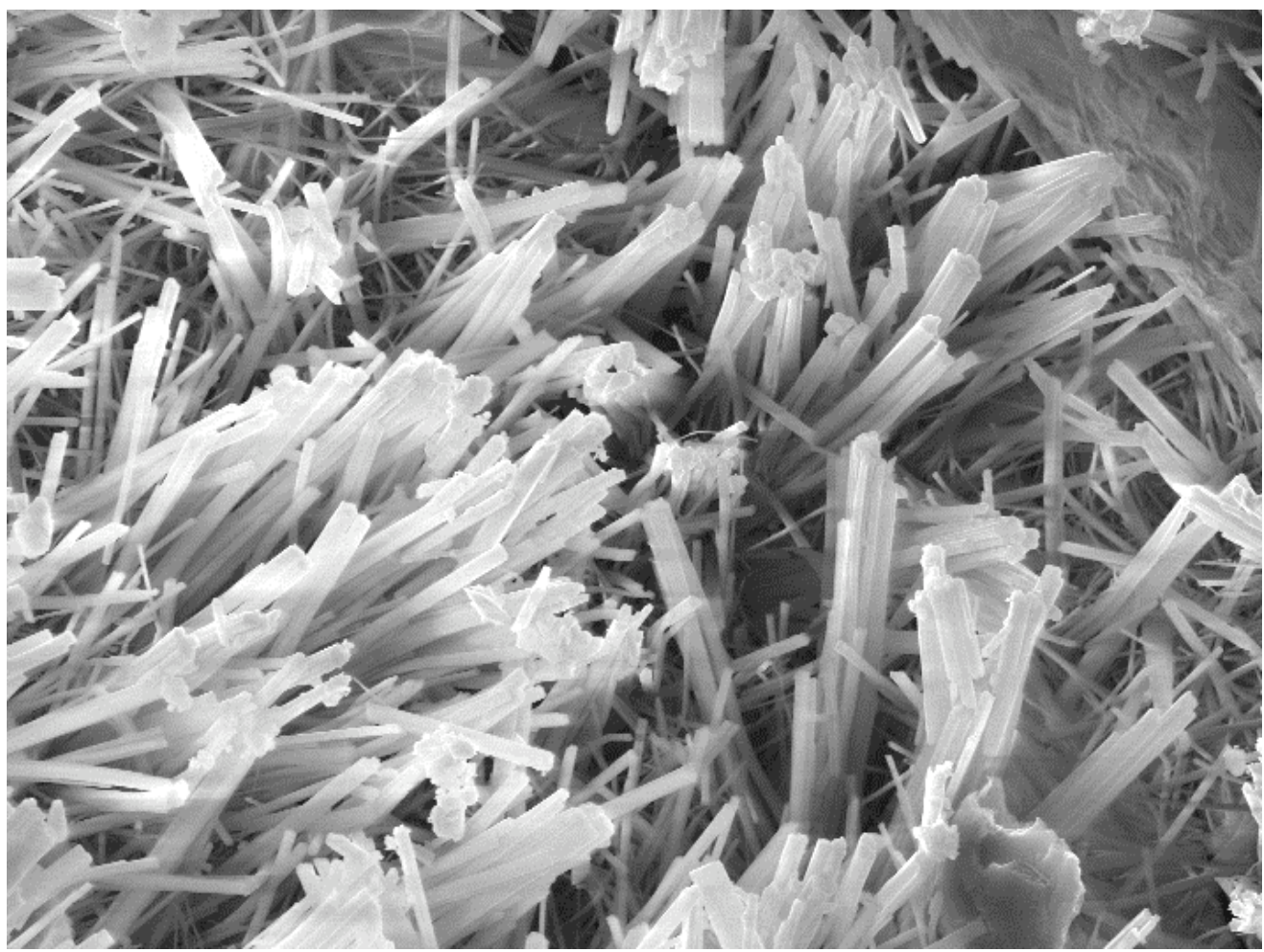

Figure 5.19 Locally, some pores are filled with well developed needles of ettringite (X 2000). 


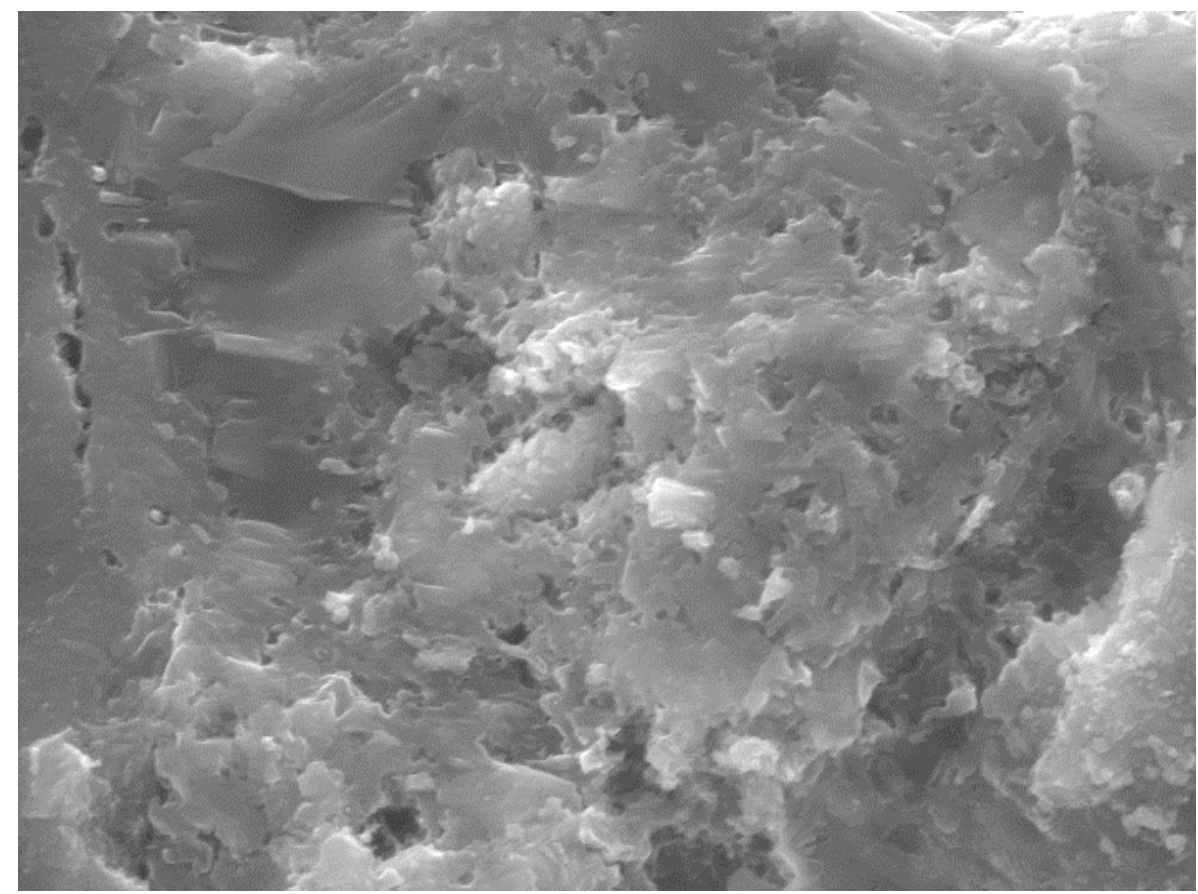

Figure 5.20 The C-S-H from the paste is typical of a neat OPC cement (X 8000).

The boundary adjacent to the solution was examined carefully to detect the presence of any new mineral. In the sample cured in $\mathrm{Na}_{2} \mathrm{HPO}_{4}$, some crystals of hydroxyapatite were found, Figs. 5.21 and 5.22. These crystals only contained calcium and phosphorous when analyzed by EDX. These crystals were not very abundant in the sample.

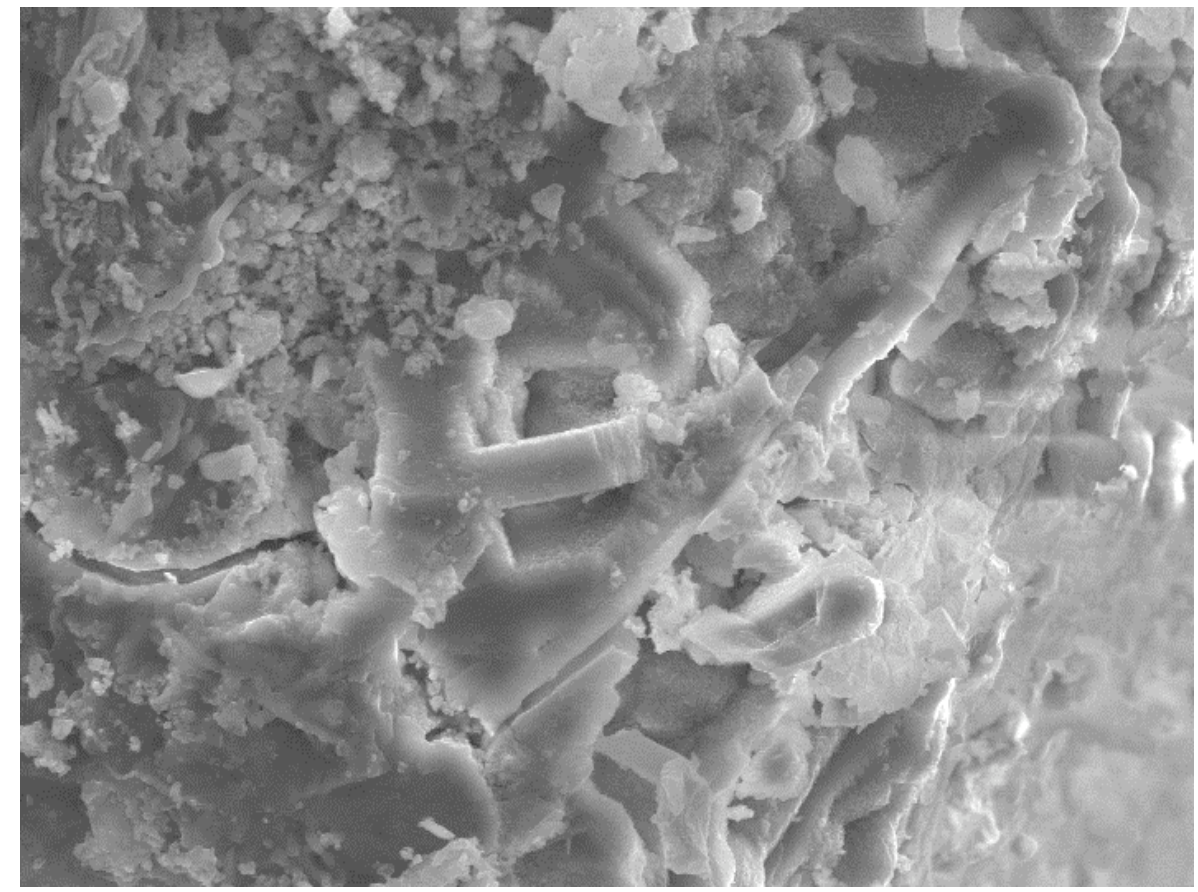

Figure 5.21 Hydroxyapatite crystals found just in contact with the curing solution (X 2000). 


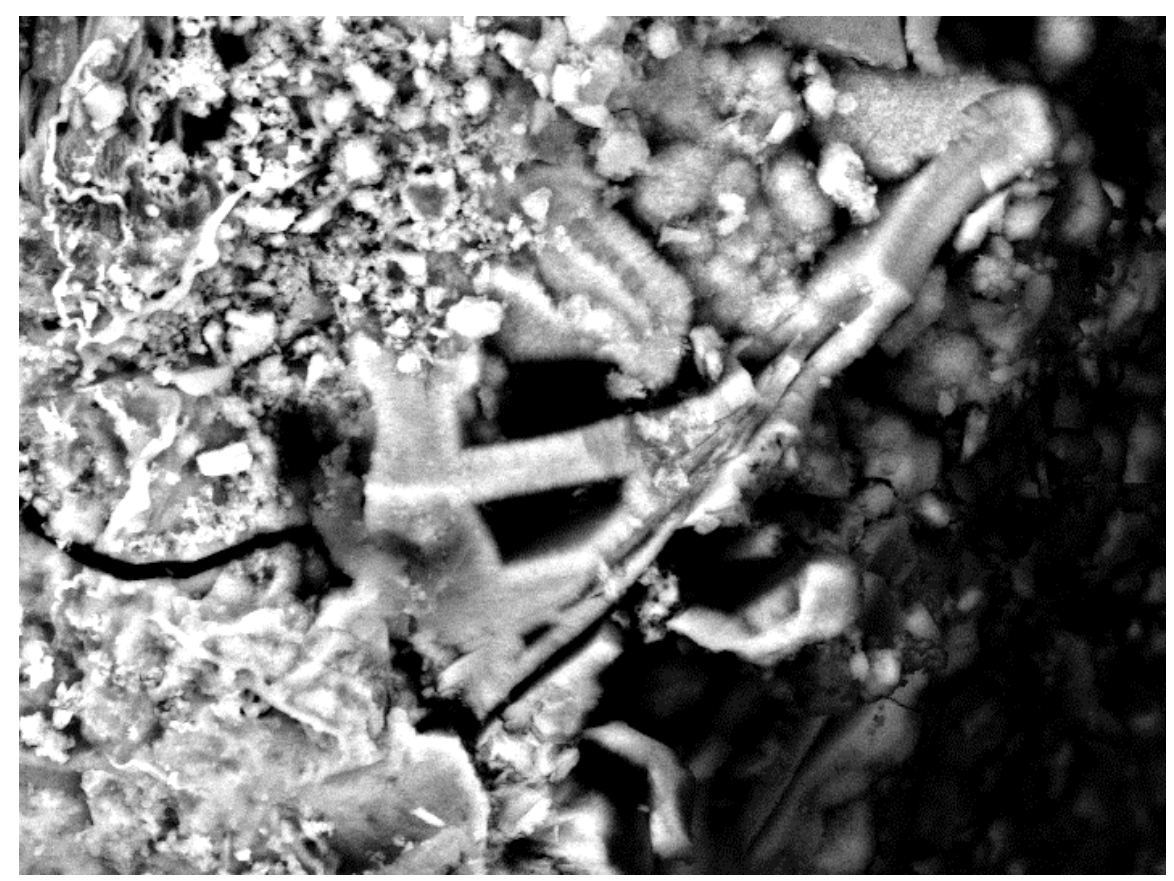

Figure 5.22 Same area (as in Fig. 5.21) in backscattered electrons. The whiter zones are rich in phosphorous (X 2000).

In the sample cured in $\mathrm{MgHPO}_{4}$, well-formed crystals of hydroxyapatite were not found, Figure 5.23.

Some small areas were enriched in phosphorous, but contained elements other than $\mathrm{Ca}$ and $\mathrm{P}$ (such as $\mathrm{Al}$, $\mathrm{Si}$ and sometimes S).

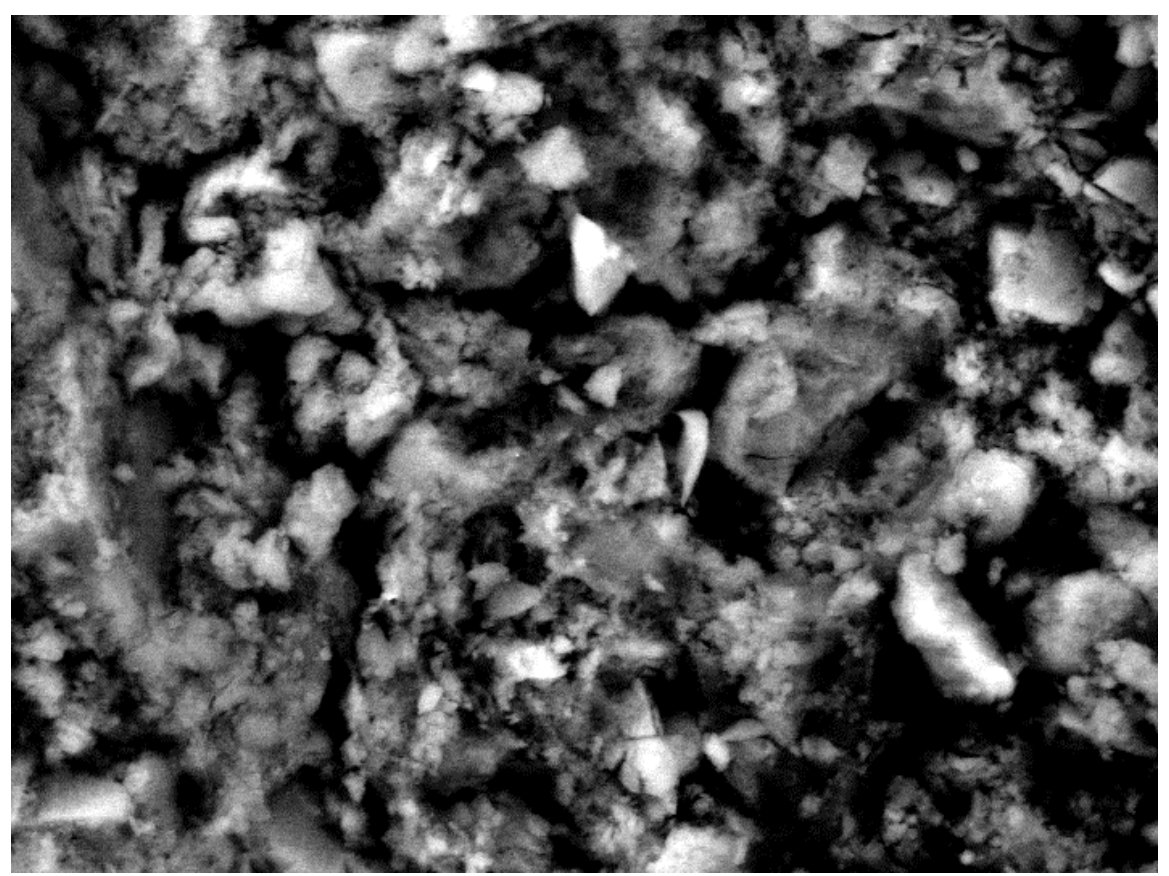

Figure 5.23 Backscattered electrons image of the samples cured in $\mathrm{MgHPO}_{4}$, near the specimen boundary. The white dots are enriched with phosphorous (X 4000). 


\subsubsection{Conclusions After Three-Months Exposure}

Experimental studies obtained over a three-month period indicate similar performance (i.e., compressive strength, weight change, and length change) of specimens cured in the two phosphate solutions $\left(\mathrm{Na}_{2} \mathrm{HPO}_{4}\right.$ and $\left.\mathrm{MgHPO}_{4}\right)$ and results from specimens cured in the control solution $\left(\mathrm{Ca}(\mathrm{OH})_{2}\right)$.

\subsection{Phosphate-Cement Interactions: Twelve-Month Results}

Figure 5.24 presents the length change and cube test specimens after being conditioned in the three solutions investigated for 12 months. The solution of $\mathrm{Na}_{2} \mathrm{HPO}_{4}$ is clear and transparent. The solution of $\mathrm{MgHPO}_{4}$ contains some carbonates floating on top of the solution, but much less than the solution of calcium hydroxide. In both the magnesium and calcium hydroxide solutions, the specimens are covered with white deposits of carbonates (magnesium and calcium, respectively).
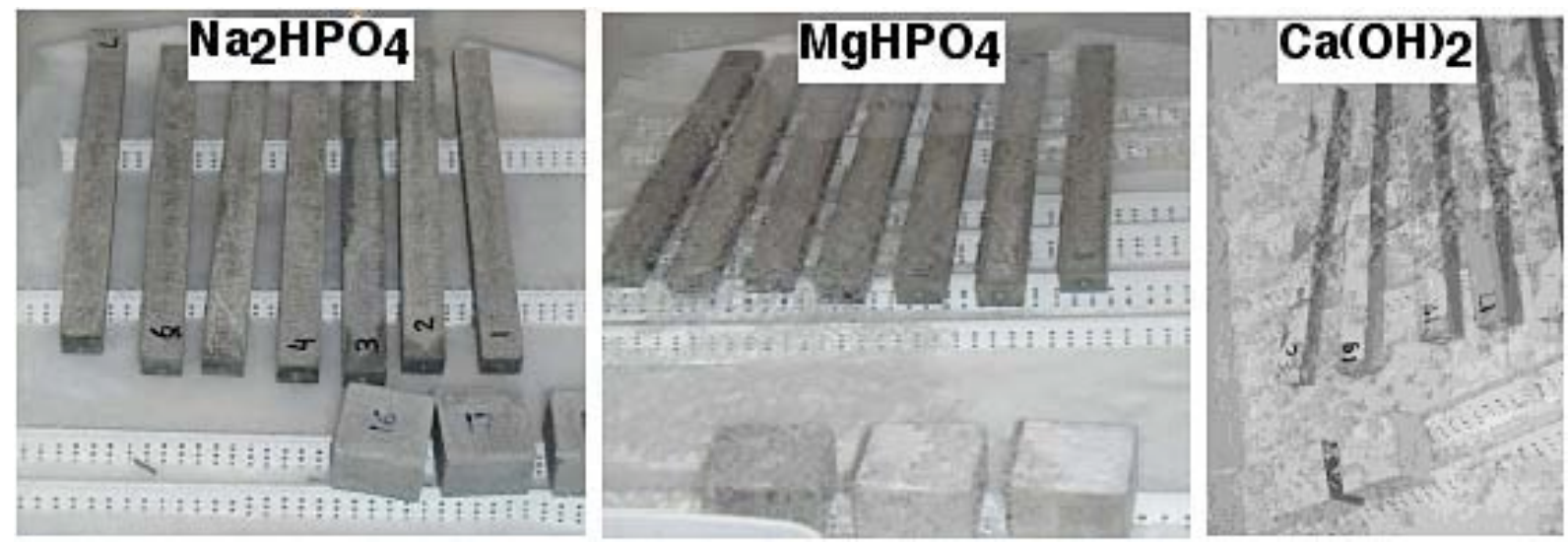

Figure 5.24 Length change and cube test specimens at 12-months exposure.

Cube specimens conditioned in the $\mathrm{Ca}(\mathrm{OH})_{2}$ solution are shown in Figure 5.25a. A close-up view of one of the cube specimens shows deposits of calcium carbonate $\left(\mathrm{CaCO}_{3}\right)$ growing on the surface (Figure 5.25b). These carbonates result from carbonation by air of the calcium hydroxide from the solution.
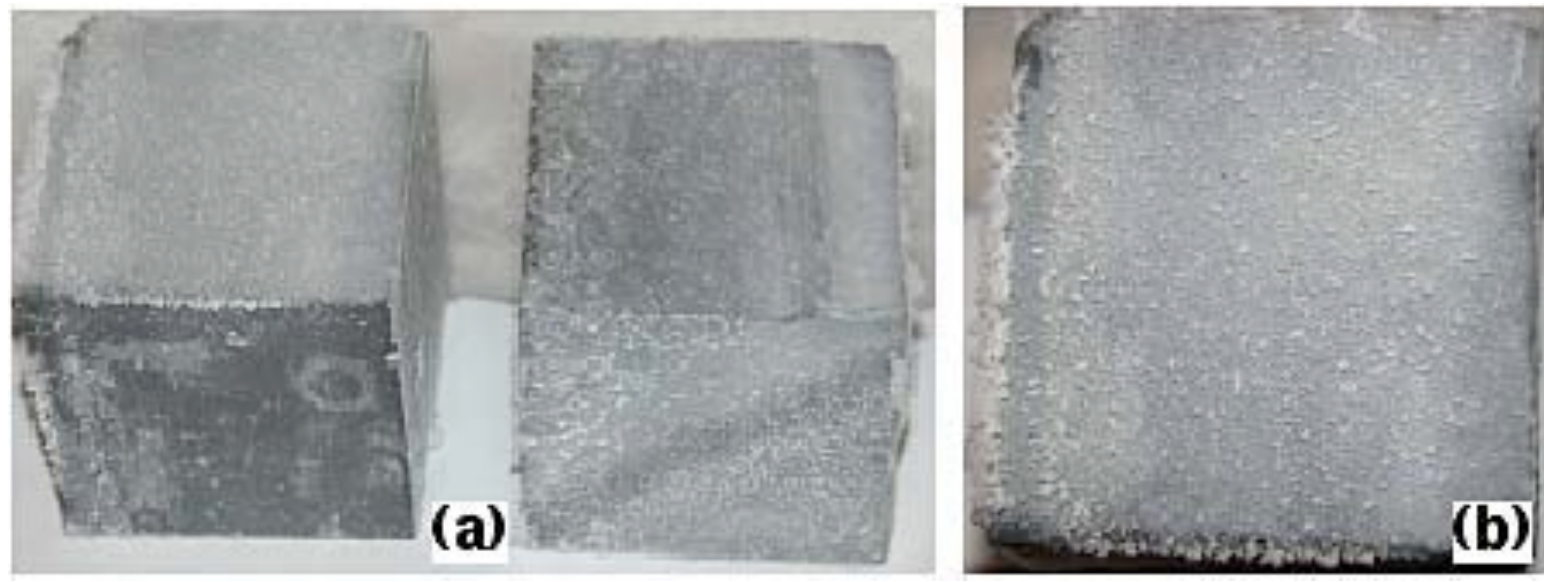

Figure 5.25 Crystals of $\mathrm{Ca}(\mathrm{CO})_{3}$ present on cube specimens stored in $\mathrm{Ca}(\mathrm{OH})_{2}$ solution 12 months. 
The specimens conditioned in both of the phosphate solutions are exhibiting the formation of small crystals growing on their sides. The crystals seen on the specimens conditioned in the magnesium phosphate solution appear to be larger and more abundant than those seen on the specimens conditioned in the sodium phosphate solution (Figure 5.26).
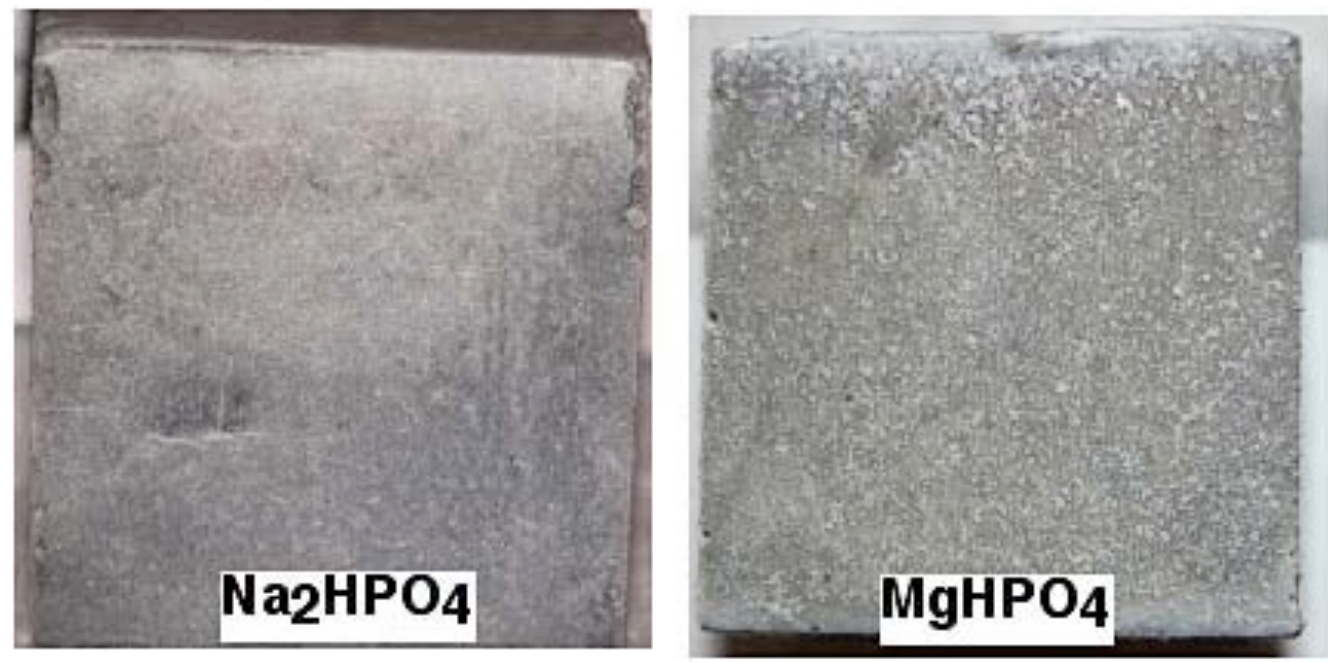

Figure 5.26 Details of surfaces of cube specimens stored in $\mathrm{Na}_{2} \mathrm{HPO}_{4}$ and $\mathrm{MgHPO}_{4}$ solutions for 12 months.

\subsubsection{Weight Change, Length Change, and Compressive Strength Results}

The samples conditioned in $\mathrm{Ca}(\mathrm{OH})_{2}$ provide the reference for comparison with the specimens conditioned in the phosphate solutions. The results obtained for length and weight changes are summarized in Figures 5.27 and 5.28, respectively.

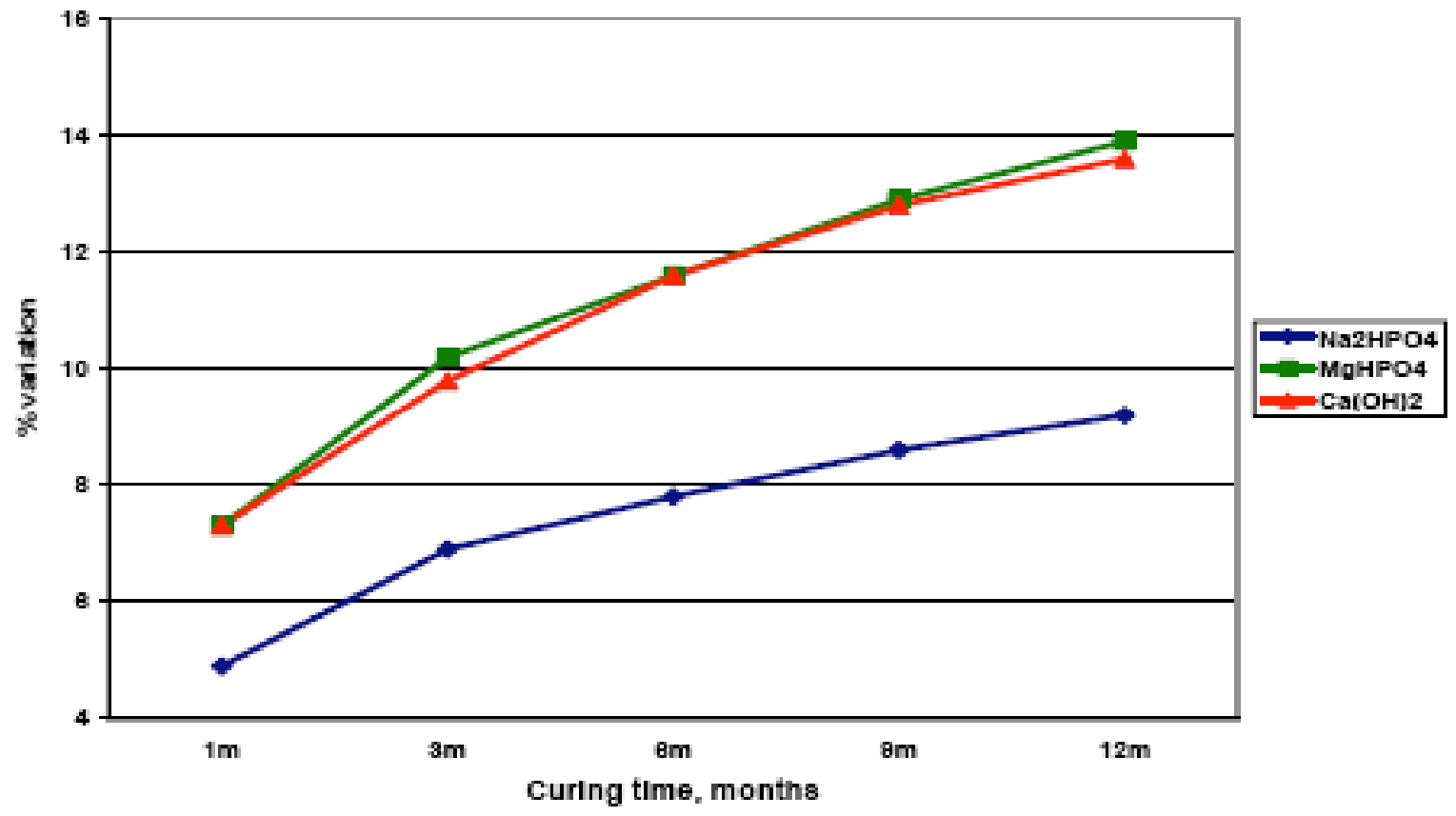

Figure 5.27 Comparison of length change results as function of time - 12 month results. 


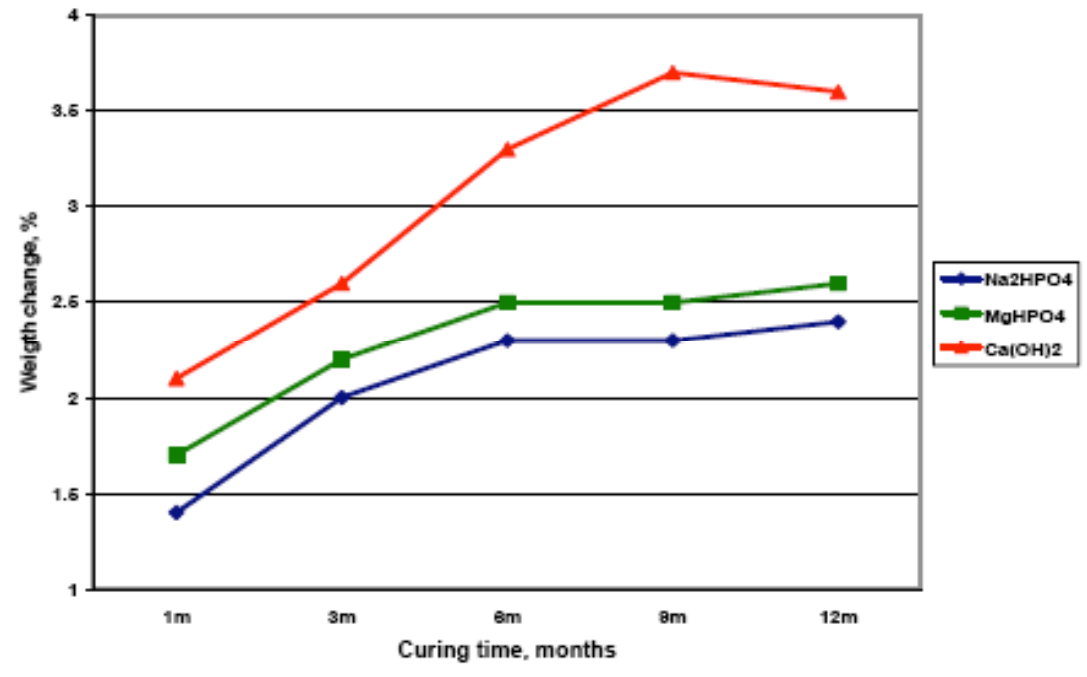

Figure 5.28 Comparison of weight change results as function of time -12 month results.

The expansion shown for the specimens conditioned in the $\mathrm{MgHPO}_{4}$ solution is comparable to that exhibited by the reference $\mathrm{Ca}(\mathrm{OH})_{2}$ solution. Results for the specimens conditioned in the $\mathrm{Na}_{2} \mathrm{HPO}_{4}$ solution exhibit a reduced length change relative to that obtained for the $\mathrm{Ca}(\mathrm{OH})_{2}$ reference.

The weight change for the specimens conditioned in the phosphate solutions is less that that obtained for specimens conditioned in the reference $\mathrm{Ca}(\mathrm{OH})_{2}$ solution. The curve obtained for the specimens conditioned in the $\mathrm{MgHPO}_{4}$ solution shows a slight increase in weight gain relative to the specimens conditioned in the $\mathrm{Na}_{2} \mathrm{HPO}_{4}$ solution. Some of the differences in weight change can be attributed to differences in the propensity of the solutions for crystal formation on the specimens surfaces (e.g., specimens conditioned in the $\mathrm{MgHPO}_{4}$ solution tend to also form carbonate crystals).

Three specimens were tested in compression after twelve months of conditioning in each of the solutions. Figure 5.29 presents a summary of results obtained to date. The error bar associated with each average result is also provided in the graph. For some results, the error bar is wide; this is

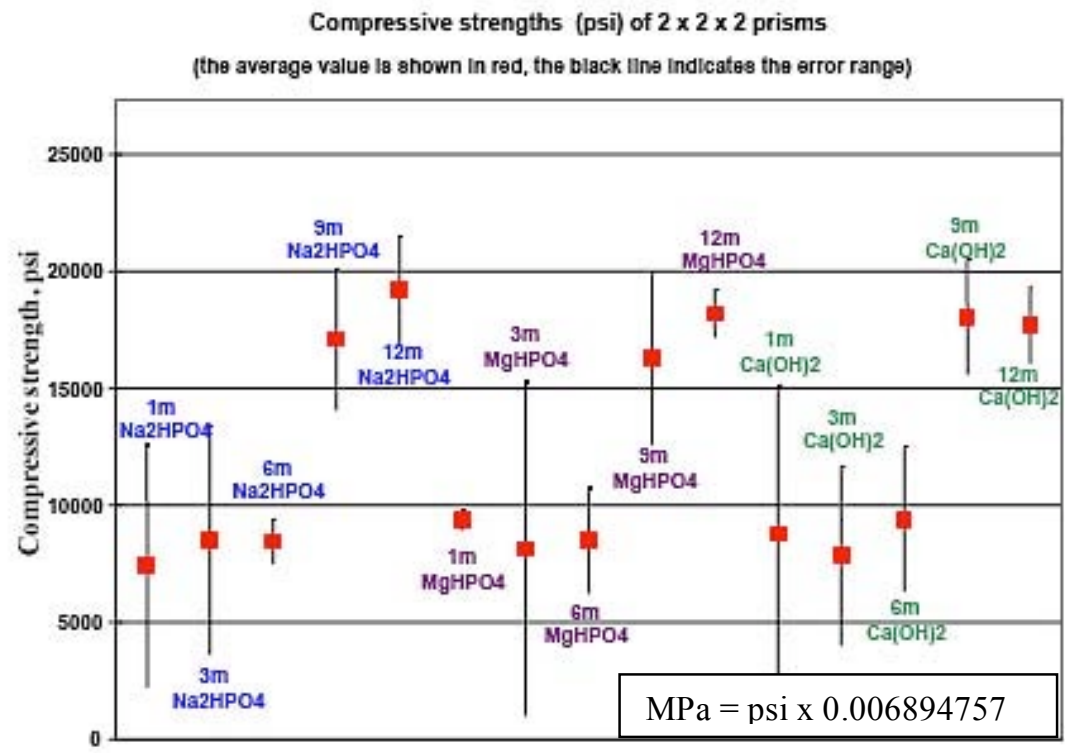

Figure 5.29 Compressive strength test results through 12 months exposure. 
usually caused by some defect present in one of the test specimens. A statistical evaluation of the measurements did not allow removing any measured value as an outlier. The results indicate that there is no significant difference between the compressive strength of specimens conditioned in the phosphate solutions and the reference $\mathrm{Ca}(\mathrm{OH})_{2}$ solution.

\subsubsection{X-ray Diffraction Results}

Specimens were examined by XRD after 12 months of conditioning in each of the solutions using the procedue described previously. The spectra obtained for samples conditioned in each of the solutions were found to be very similar. Hydrated phases identified included: Portlandite $\left[\mathrm{Ca}(\mathrm{OH})_{2}\right]$, C-S-H (calcium silicate hydrates), and possibly Ettringite. Peaks of non-hydrated cement phases identified included: $\mathrm{C}_{4} \mathrm{AF}$ (Brownmillerite), $\mathrm{C}_{3} \mathrm{~S}$ (tricalcium silicate) and $\mathrm{C}_{2} \mathrm{~S}$ (dicalcium silicate). No mineral containing phosphate was identified. X-ray diffraction spectra for material from specimens conditioned in $\mathrm{Ca}(\mathrm{OH})_{2}, \mathrm{Na}_{2} \mathrm{HPO}_{4}$, and $\mathrm{MgHPO}_{4}$, are presented in Figures 5.30-5.32, respectively.

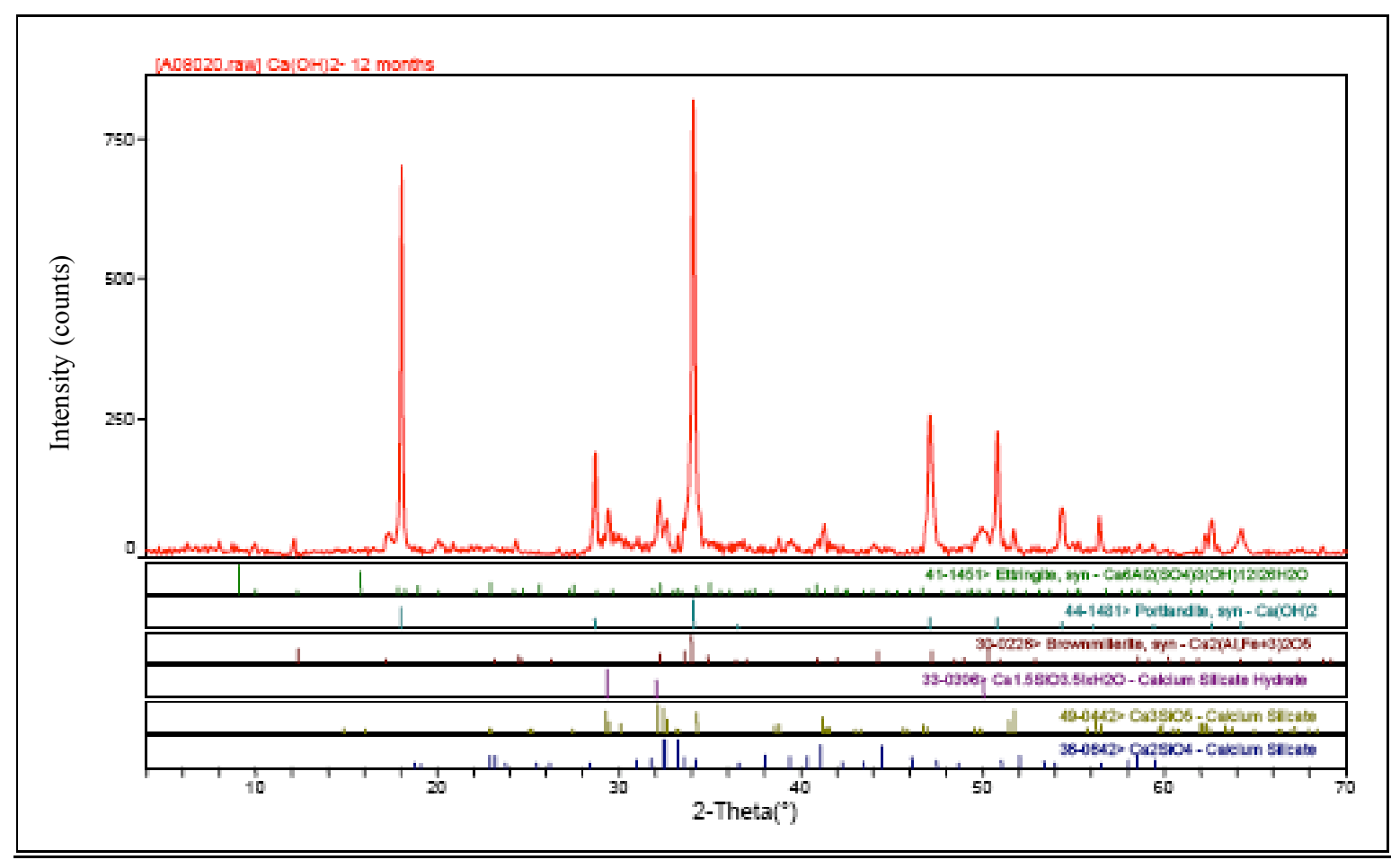

Figure 5.30 XRD spectrum of specimen conditioned 12 months in $\mathrm{Ca}(\mathrm{OH})_{2}$. 


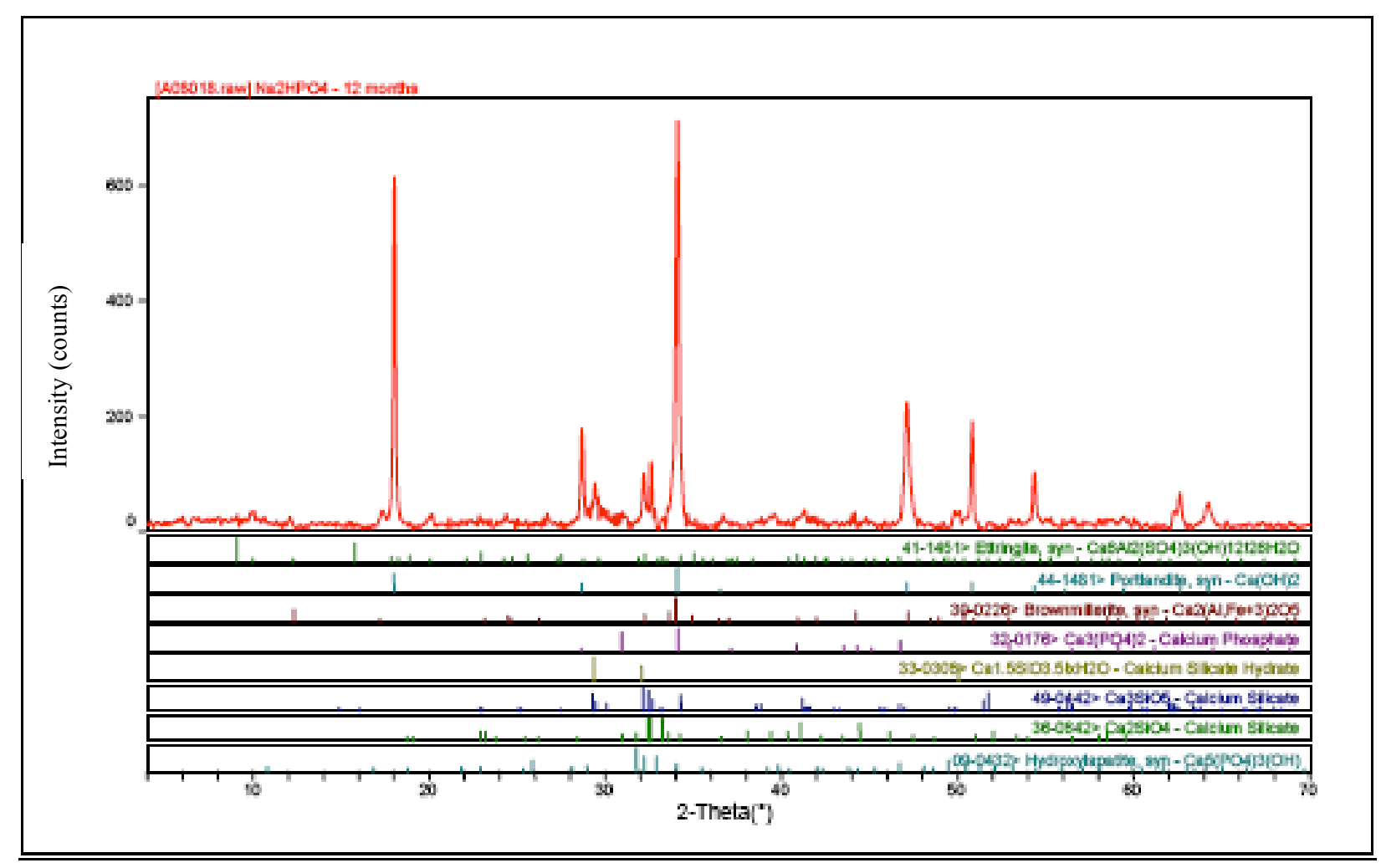

Figure 5.31 XRD spectrum of specimen conditioned 12 months in $\mathrm{Na}_{2} \mathrm{HPO}_{4}$.

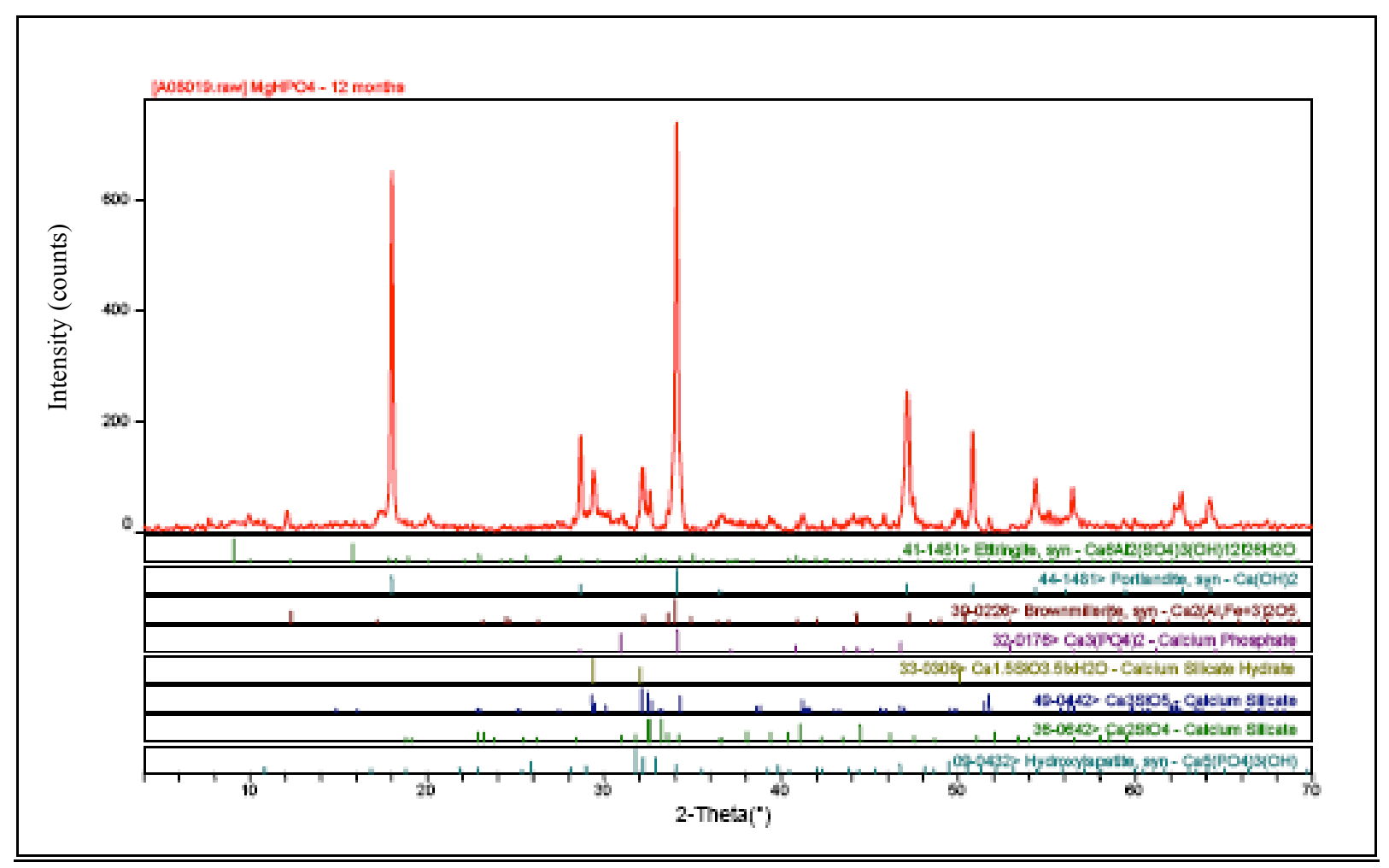

Figure 5.32 XRD spectrum of specimen conditioned 12 months in $\mathrm{MgHPO}_{4}$. 


\subsubsection{SEM Examination Results}

The scanning-electron microscope (SEM) examinations performed on specimens after 12 months of conditioning in each of the solutions confirmed the results found by X-ray diffraction. Phosphatecontaining crystals were not observed in the specimens even at locations close to the exposed surfaces of the cement paste cubes. Mineralogical phases observed were C-S-H, Ettringite, Portlandite, calcium sulfoaluminates and non-hydrated clinker. These phases are typical of those observed in cement paste specimens that had been cured under control conditions [e.g., in a $\mathrm{Ca}(\mathrm{OH})_{2}$ solution]. The cement paste did not appear to have been modified as a result of the 12 months of conditioning in the phosphate solutions. Figures $5.33-5.37$ provide SEM results showing typical phases observed in specimens that had been conditioned in the $\mathrm{Na}_{2} \mathrm{HPO}_{4}$ and $\mathrm{MgHPO}_{4}$ solutions.

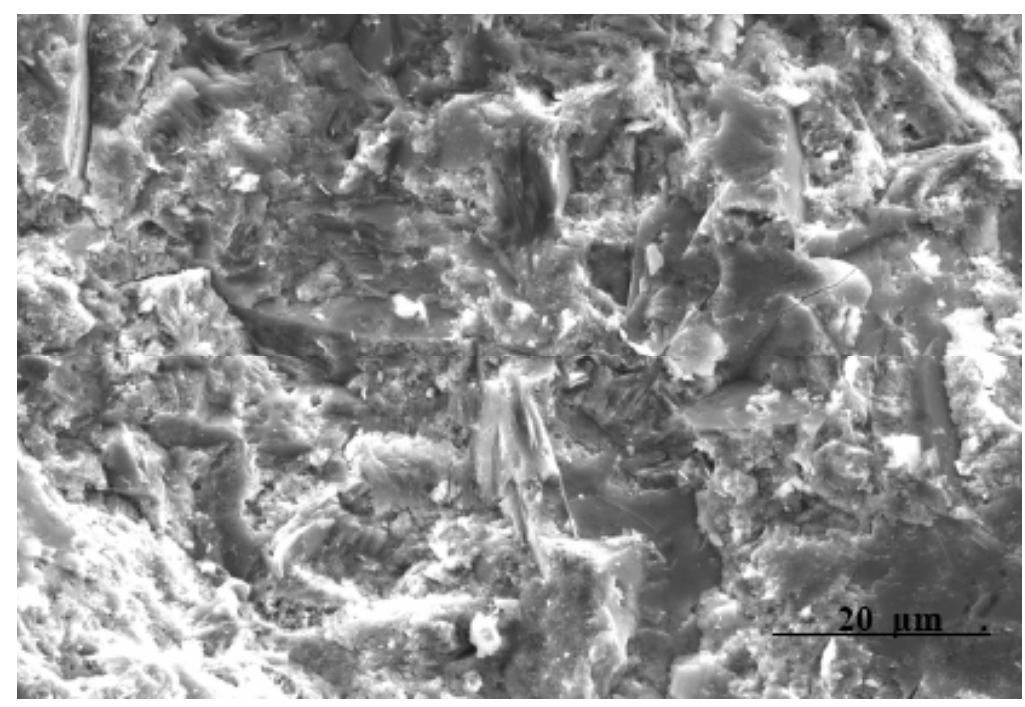

Figure 5.33 SEM result showing cement paste - 12 months conditioning in $\mathrm{Na}_{2} \mathrm{HPO}_{4}$ solution.

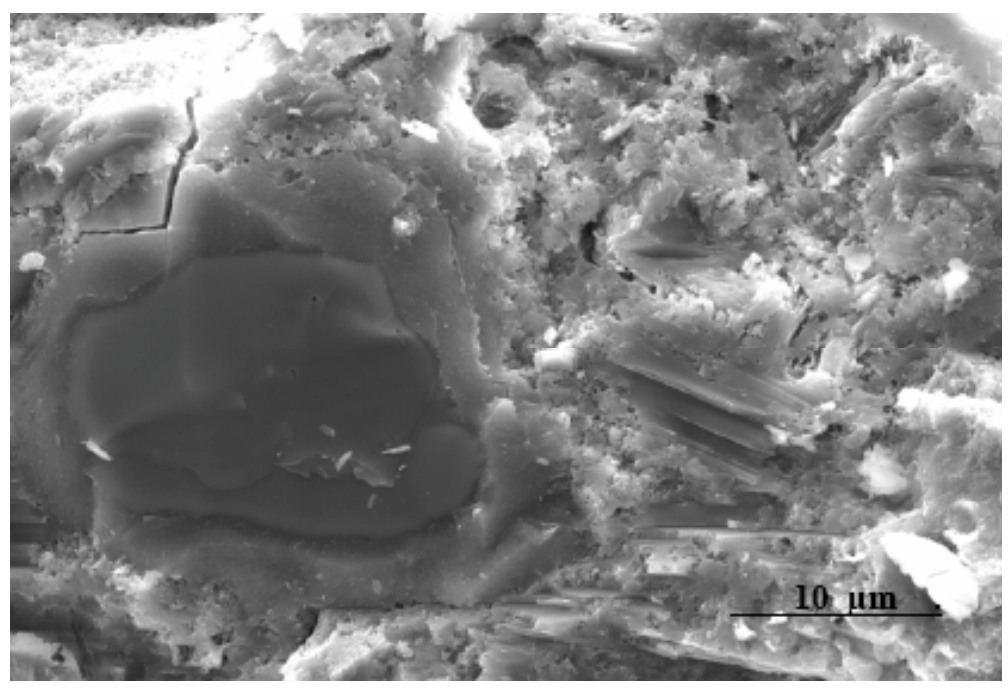

Figure 5.34 SEM result showing $\mathrm{C}_{3} \mathrm{~S}$ surrounded by dense layer of $\mathrm{C}-\mathrm{S}-\mathrm{H}$ 12 months conditioning in $\mathrm{Na}_{2} \mathbf{H P O}_{4}$ solution $\left[\mathrm{Ca}(\mathrm{OH})_{2}\right.$ and calcium sulfoaluminates visible in cement paste]. 


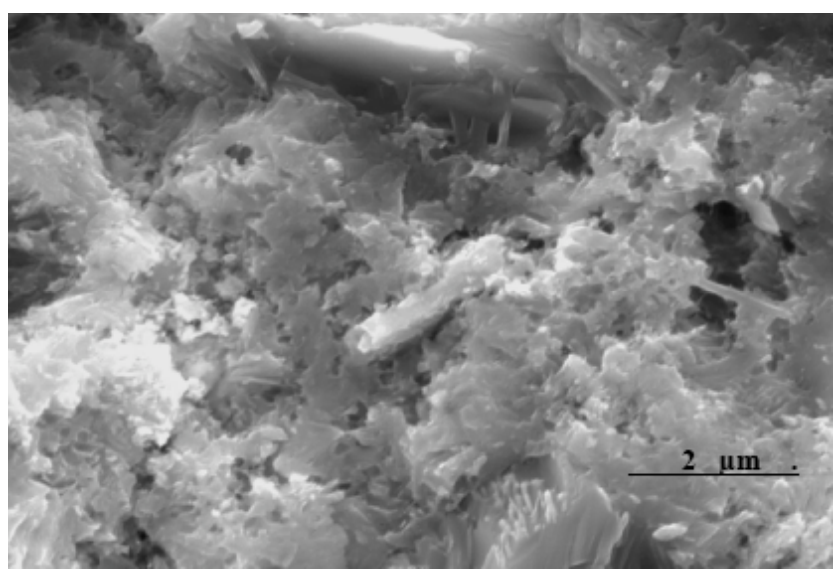

Figure 5.35 SEM result showing C-S-H and sulfoaluminates 12 months conditioning in $\mathrm{Na}_{2} \mathrm{HPO}_{4}$ solution.

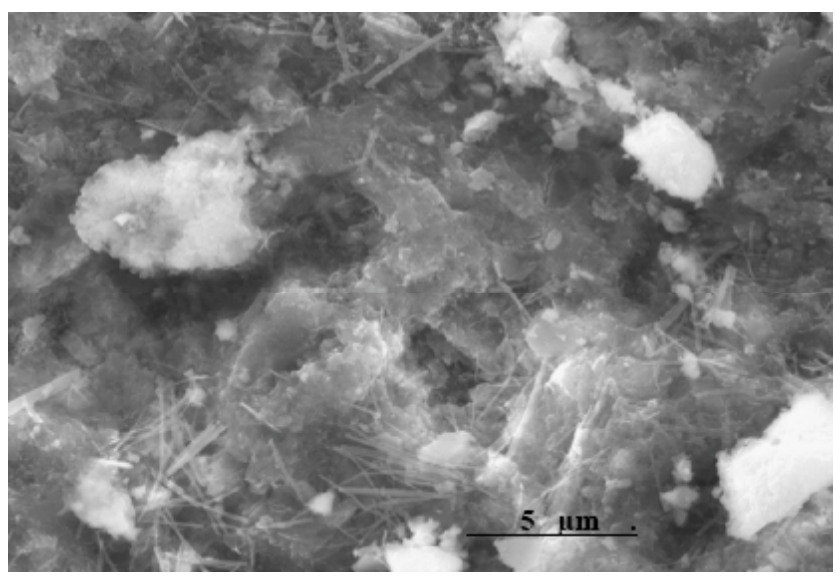

Figure 5.36 SEM result showing Ettringite in cement paste 12 months conditioning in $\mathrm{MgHPO}_{4}$ solution.

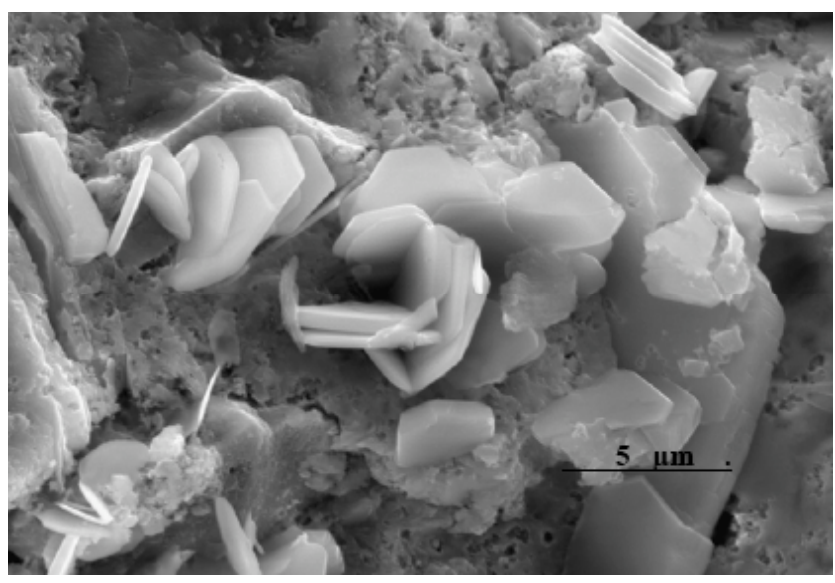

Figure 5.37 SEM result showing calcium sulfoaluminates 12 months conditioning in $\mathrm{MgHPO}_{4}$ solution. 


\subsubsection{Conclusions After Twelve-Months Exposure}

After 12 months of conditioning in either of the phosphate solutions the specimens exhibited either an equivalent length change $\left(\mathrm{MgHPO}_{4}\right)$ or a reduced length change $\left(\mathrm{Na}_{2} \mathrm{HPO}_{4}\right)$ relative to that obtained from specimens conditioned in the reference $\mathrm{Ca}(\mathrm{OH})_{2}$ solution. Weight gains exhibited by specimens conditioned for 12 months in the phosphate solutions were similar, but less than that observed for specimens conditioned in the reference $\mathrm{Ca}(\mathrm{OH})_{2}$ solution. The weight gain exhibited by specimens conditioned in the $\mathrm{Na}_{2} \mathrm{HPO}_{4}$ was slightly less than that obtained for specimens conditioned in the $\mathrm{MgHPO}_{4}$ solution. Compressive strength results obtained for specimens conditioned in the phosphate solutions were comparable to those obtained from specimens conditioned in the reference $\mathrm{Ca}(\mathrm{OH})_{2}$ solution. X-ray diffraction and scanning-electron microscope results indicate that similar mineralogical phases have been observed for specimens conditioned in the phosphate solutions and the reference $\mathrm{Ca}(\mathrm{OH})_{2}$ solution. Phosphate-containing crystals have not been observed in specimens conditioned in either of the phosphate solutions. After 12 months of conditioning no signs of deleterious effects of phosphate salts on cement pastes have been observed.

\subsection{Phosphate-Cement Interactions: Eighteen-Month Results}

Figure 5.38 shows the length change specimens after conditioning in $\mathrm{Ca}(\mathrm{OH})_{2}$ for 18 months. A closer view of the specimens showing a layer of $\mathrm{CaCO}_{3}$ on the surface is presented in Figure 5.39. Specimens

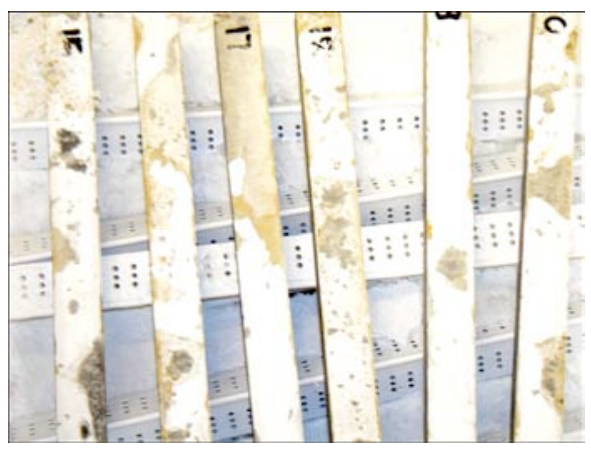

Figure 5.38 Specimens after 18-month exposure in solution of $\mathrm{Ca}(\mathrm{OH})_{2}$.

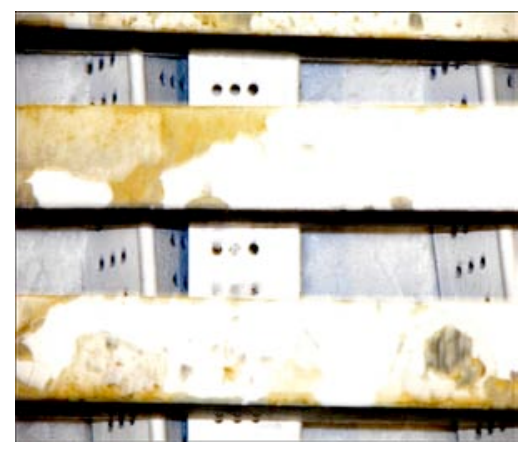

Figure 5.39 Closeup of specimens after 18month exposure in solution of $\mathrm{Ca}(\mathrm{OH})_{2}$.

cured in the $\mathrm{Ca}(\mathrm{OH})_{2}$ solution exhibit deposits of $\mathrm{CaCO}_{3}$ growing on the surface as noted in Figure 5.40. These deposits result from the carbonation by air of the $\mathrm{Ca}(\mathrm{OH})_{2}$ from the solution.

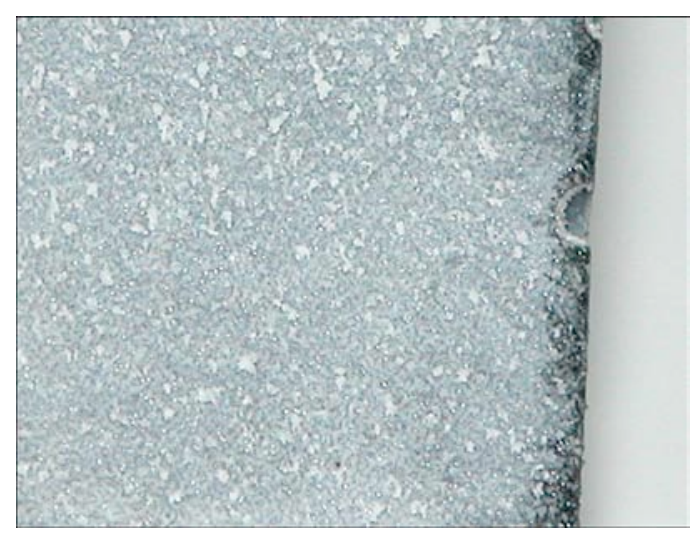

Figure 5.40 $\mathrm{CaCO}_{3}$ deposits on surface of specimen cured in $\mathrm{Ca}(\mathrm{OH})_{2}$. 
The $\mathrm{Na}_{2} \mathrm{HPO}_{4}$ solution remained clear and transparent over the 18-month test duration as shown in Figures 5.41 and 5.42. Excess salts are present on the specimen upper surfaces. Figure 5.43 shows crystal growth on a specimen cured in the $\mathrm{Na}_{2} \mathrm{HPO}_{4}$ solution. The crystals are likely to be carbonates $\left[\mathrm{MgCO}_{3}\right.$ or $\left.(\mathrm{Ca}, \mathrm{Mg}) \mathrm{CO}_{3}\right]$ similar to those seen on the specimen cured in the $\mathrm{Ca}(\mathrm{OH})_{2}$ solution.

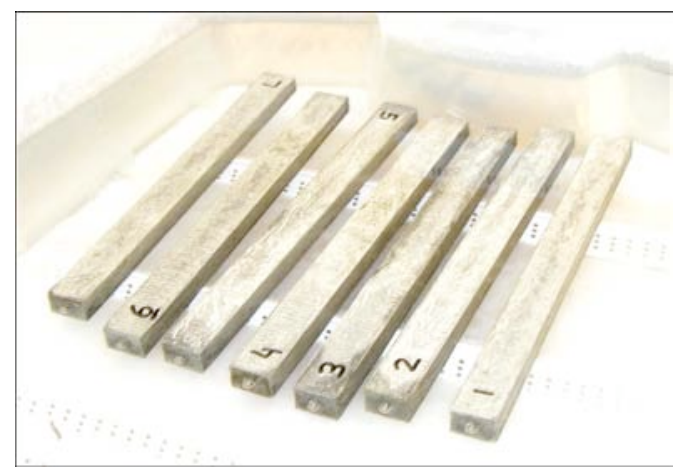

Figure 5.41 Specimens after 18-month exposure in solution of $\mathrm{Na}_{2} \mathrm{HPO}_{4}$.

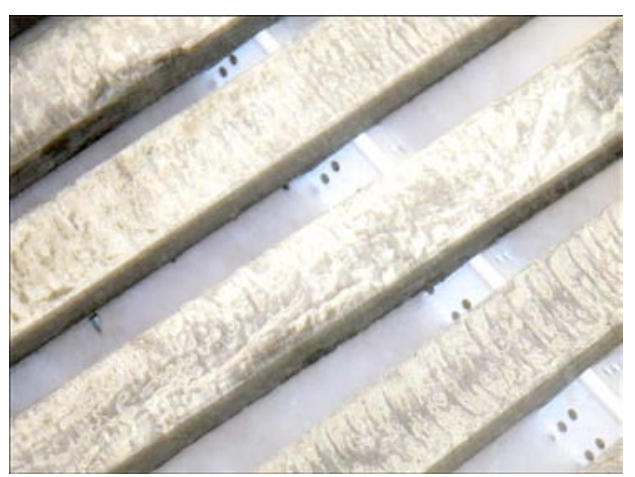

Figure 5.42 Closeup of specimens after 18month exposure in solution of $\mathrm{Na}_{2} \mathrm{HPO}_{4}$.

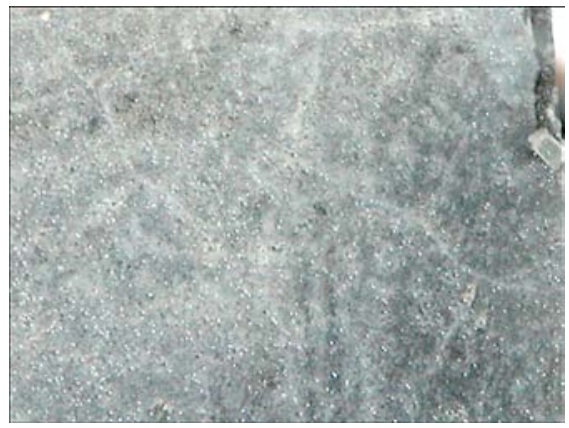

Figure 5.43 Carbonate crystal deposits on surface of specimen cured in $\mathrm{Na}_{2} \mathrm{HPO}_{4}$.

The $\mathrm{MgHPO}_{4}$ solution contained some carbonates floating on top of the solution as shown in Figures 5.44 and 5.45, but the amount was much less than observed for the $\mathrm{Ca}(\mathrm{OH})_{2}$ solution. Excess salts are present on upper surfaces of specimens cured in the $\mathrm{MgHPO}_{4}$ solution. The crystals observed on the surfaces of

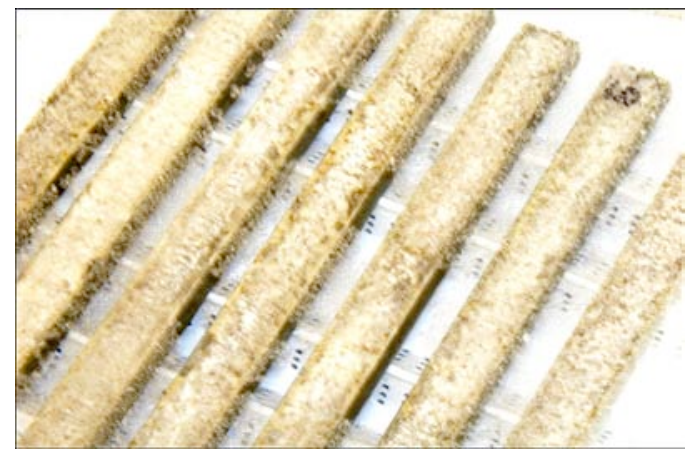

Figure 5.44 Specimens after 18-month exposure in solution of $\mathrm{MgHPO}_{4}$.

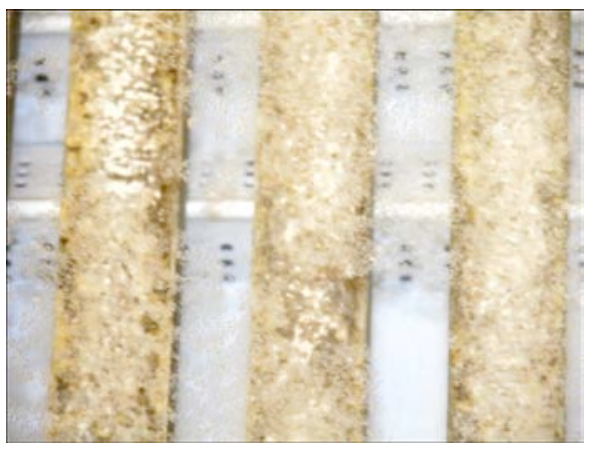

Figure 5.45 Closeup of specimens after 18month exposure in solution of $\mathrm{MgHPO}_{4}$. 
the specimens cured in the $\mathrm{MgHPO}_{4}$ solution (Figure 5.46) appear to be larger and more abundant than those observed on the specimens cured in the $\mathrm{Na}_{2} \mathrm{HPO}_{4}$ solution.

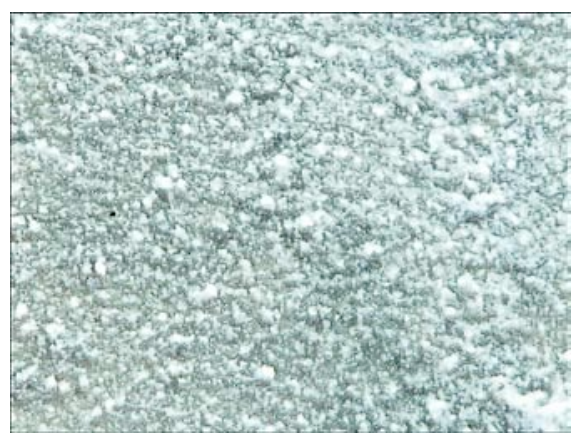

Figure 5.46 Carbonate crystal deposits on surface of specimen cured in $\mathrm{MgHPO}_{4}$.

Surfaces of specimens cured in the $\mathrm{Na}_{2} \mathrm{HPO}_{4}$ and $\mathrm{MgHPO}_{4}$ solutions are not showing any signs of cracking or spalling such as would be observed if the curing solutions were aggressive or deleterious.

\subsubsection{Weight Change, Length Change, and Compressive Strength Results}

The samples conditioned in $\mathrm{Ca}(\mathrm{OH})_{2}$ provide the reference for comparison with the specimens conditioned in the phosphate solutions.

The results obtained for length change are summarized in Figure 5.47. The length increase for the $\mathrm{Na}_{2} \mathrm{HPO}_{4}$ was measured to be around 11 percent while the increase for the $\mathrm{Ca}(\mathrm{OH})_{2}$ and $\mathrm{MgHPO}_{4}$ was found to be around 15 percent. The increase in length observed for all the specimens was probably caused by an expansion created by carbonates developing inside the cement paste matrix. The actual data utilized to prepare these figures is found in Tables 5.10 to 5.12 for samples cured in $\mathrm{Na}_{2} \mathrm{HPO}_{4}$, $\mathrm{MgHPO}_{4}$, and $\mathrm{Ca}(\mathrm{OH})_{2}$, respectively.

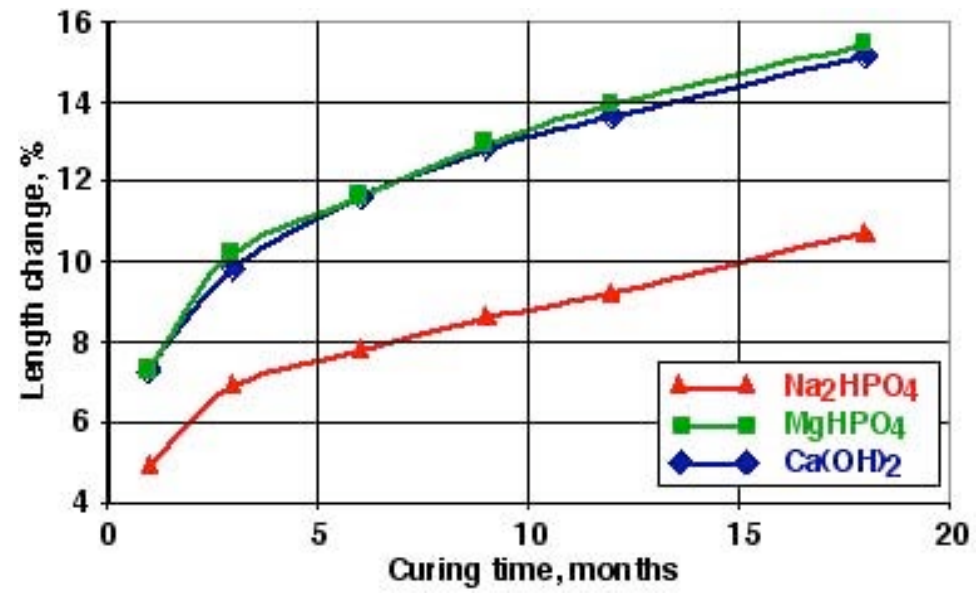

Figure 5.47 Comparison of length change results as function of time - 18 month results.

The results obtained for weight change are summarized in Figure 5.48. The weight change for the specimens conditioned in the phosphate solutions is less that that obtained for specimens conditioned in the reference $\mathrm{Ca}(\mathrm{OH})_{2}$ solution. The results obtained for the specimens conditioned in the $\mathrm{MgHPO}_{4}$ 
Table 5.10 Length and weight change for specimens cured in $\mathrm{Na}_{2} \mathrm{HPO}_{4}$.

Sample Number

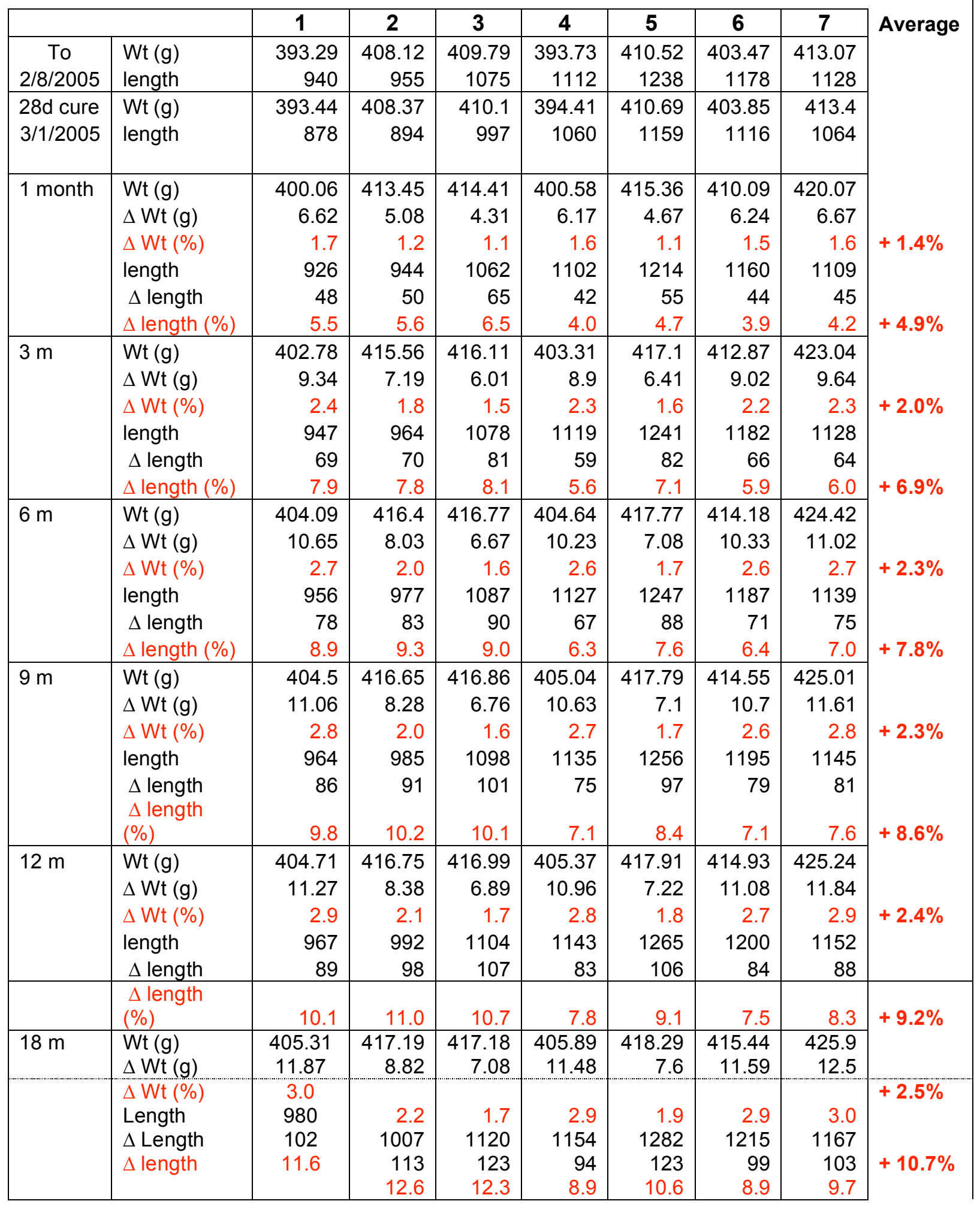


Table 5.11 Length and weight change for specimens cured in $\mathrm{MgHPO}_{4}$.

\begin{tabular}{|c|c|c|c|c|c|c|c|c|c|}
\hline & & \multicolumn{7}{|c|}{ Sample Number } & \\
\hline & & 8 & 9 & 10 & 11 & 12 & 13 & 14 & \\
\hline $\begin{array}{c}\text { To } \\
2 / 8 / 2005\end{array}$ & $\begin{array}{l}\text { Wt (g) } \\
\text { length }\end{array}$ & $\begin{array}{r}401.15 \\
1116\end{array}$ & $\begin{array}{r}413.52 \\
1167\end{array}$ & $\begin{array}{r}408.48 \\
952\end{array}$ & $\begin{array}{r}405.18 \\
957\end{array}$ & $\begin{array}{r}399.87 \\
1136\end{array}$ & $\begin{array}{r}403.83 \\
1052\end{array}$ & $\begin{array}{r}401.45 \\
1030\end{array}$ & \\
\hline $\begin{array}{l}28 d \text { cure } \\
3 / 1 / 2005\end{array}$ & $\begin{array}{l}\text { Wt (g) } \\
\text { length }\end{array}$ & $\begin{array}{r}401.06 \\
1038\end{array}$ & $\begin{array}{r}413.32 \\
1081\end{array}$ & $\begin{array}{r}407.89 \\
885\end{array}$ & $\begin{array}{r}405.89 \\
904\end{array}$ & $\begin{array}{r}400.07 \\
1067\end{array}$ & $\begin{array}{r}403.99 \\
968\end{array}$ & $\begin{array}{r}401.92 \\
963\end{array}$ & \\
\hline 1 month & $\begin{array}{l}\text { Wt }(\mathrm{g}) \\
\Delta \mathrm{Wt}(\mathrm{g}) \\
\Delta \mathrm{Wt}(\%) \\
\text { length } \\
\Delta \text { length } \\
\Delta \text { length }(\%)\end{array}$ & $\begin{array}{r}408.18 \\
7.12 \\
1.8 \\
1107 \\
69 \\
6.6\end{array}$ & $\begin{array}{r}418.16 \\
4.84 \\
1.2 \\
1158 \\
77 \\
7.1\end{array}$ & $\begin{array}{r}416.92 \\
9.03 \\
2.2 \\
955 \\
70 \\
7.9\end{array}$ & $\begin{array}{r}414.58 \\
8.69 \\
2.1 \\
969 \\
65 \\
7.2\end{array}$ & $\begin{array}{r}405.06 \\
4.99 \\
1.2 \\
1134 \\
67 \\
6.3\end{array}$ & $\begin{array}{r}408.71 \\
4.72 \\
1.2 \\
1049 \\
81 \\
8.4\end{array}$ & $\begin{array}{r}409.68 \\
7.76 \\
1.9 \\
1034 \\
71 \\
7.4\end{array}$ & $+1.7 \%$ avg \\
\hline $3 \mathrm{~m}$ & $\begin{array}{l}\text { Wt }(\mathrm{g}) \\
\Delta \mathrm{Wt}(\mathrm{g}) \\
\Delta \mathrm{Wt}(\%) \\
\text { length } \\
\Delta \text { length } \\
\Delta \text { length }(\%)\end{array}$ & $\begin{array}{r}410.64 \\
9.58 \\
2.4 \\
1132 \\
94 \\
9.1 \\
\end{array}$ & $\begin{array}{r}420.4 \\
7.08 \\
1.7 \\
1183 \\
102 \\
9.4 \\
\end{array}$ & $\begin{array}{r}418.93 \\
11.04 \\
2.7 \\
986 \\
101 \\
11.4 \\
\end{array}$ & $\begin{array}{r}416.5 \\
10.61 \\
2.6 \\
1000 \\
96 \\
10.6 \\
\end{array}$ & $\begin{array}{r}407.4 \\
7.33 \\
1.8 \\
1162 \\
95 \\
8.9 \\
\end{array}$ & $\begin{array}{r}410.6 \\
6.61 \\
1.6 \\
1082 \\
114 \\
11.8 \\
\end{array}$ & $\begin{array}{r}411.99 \\
10.07 \\
2.5 \\
1060 \\
97 \\
10.1 \\
\end{array}$ & $+10.2 \%$ avg \\
\hline $6 \mathrm{~m}$ & $\begin{array}{l}\text { Wt }(\mathrm{g}) \\
\Delta \mathrm{Wt}(\mathrm{g}) \\
\Delta \mathrm{Wt}(\%) \\
\text { length } \\
\Delta \text { length } \\
\Delta \text { length }(\%)\end{array}$ & $\begin{array}{r}412.04 \\
10.98 \\
2.7 \\
1148 \\
110 \\
10.6 \\
\end{array}$ & $\begin{array}{r}421.38 \\
8.06 \\
2.0 \\
1198 \\
117 \\
10.8 \\
\end{array}$ & $\begin{array}{r}419.78 \\
11.89 \\
2.9 \\
998 \\
113 \\
12.8 \\
\end{array}$ & $\begin{array}{r}417.66 \\
11.77 \\
2.9 \\
1012 \\
108 \\
11.9 \\
\end{array}$ & $\begin{array}{r}408.58 \\
8.51 \\
2.1 \\
1177 \\
110 \\
10.3 \\
\end{array}$ & $\begin{array}{r}411.56 \\
7.57 \\
1.9 \\
1095 \\
127 \\
13.1 \\
\end{array}$ & $\begin{array}{r}413.28 \\
11.36 \\
2.8 \\
1077 \\
114 \\
11.8 \\
\end{array}$ & $+11.6 \%$ avg \\
\hline $9 \mathrm{~m}$ & $\begin{array}{l}\text { Wt }(\mathrm{g}) \\
\Delta \mathrm{Wt}(\mathrm{g}) \\
\Delta \mathrm{Wt}(\%) \\
\text { length } \\
\Delta \text { length } \\
\Delta \text { length }(\%)\end{array}$ & $\begin{array}{r}412.29 \\
11.23 \\
2.8 \\
1160 \\
122 \\
11.8 \\
\end{array}$ & $\begin{array}{r}421.6 \\
8.28 \\
2.0 \\
1208 \\
127 \\
11.7 \\
\end{array}$ & $\begin{array}{r}420.11 \\
12.22 \\
3.0 \\
1013 \\
128 \\
14.5 \\
\end{array}$ & $\begin{array}{r}417.88 \\
11.99 \\
3.0 \\
1029 \\
125 \\
13.8 \\
\end{array}$ & $\begin{array}{r}408.99 \\
8.92 \\
2.2 \\
1185 \\
118 \\
11.1 \\
\end{array}$ & $\begin{array}{r}411.73 \\
7.74 \\
1.9 \\
1108 \\
140 \\
14.5 \\
\end{array}$ & $\begin{array}{r}413.75 \\
11.83 \\
2.9 \\
1088 \\
125 \\
13.0 \\
\end{array}$ & $+2.5 \%$ avg \\
\hline $12 \mathrm{~m}$ & $\begin{array}{l}\text { Wt }(\mathrm{g}) \\
\Delta \mathrm{Wt}(\mathrm{g}) \\
\Delta \mathrm{Wt}(\%) \\
\text { length } \\
\Delta \text { length } \\
\Delta \text { length }(\%)\end{array}$ & $\begin{array}{r}412.59 \\
11.53 \\
2.9 \\
1170 \\
132 \\
12.7\end{array}$ & $\begin{array}{r}421.68 \\
8.36 \\
2.0 \\
1215 \\
134 \\
12.4\end{array}$ & $\begin{array}{r}420.44 \\
12.55 \\
3.1 \\
1027 \\
142 \\
16.0\end{array}$ & $\begin{array}{r}418.12 \\
12.23 \\
3.0 \\
1040 \\
136 \\
15.0\end{array}$ & $\begin{array}{r}409.05 \\
8.98 \\
2.2 \\
1196 \\
129 \\
12.1\end{array}$ & \begin{tabular}{r|}
412.07 \\
8.08 \\
2.0 \\
1114 \\
146 \\
15.1
\end{tabular} & $\begin{array}{r}413.96 \\
12.04 \\
3.0 \\
1094 \\
131 \\
13.6\end{array}$ & $+2.6 \%$ avg \\
\hline $18 \mathrm{~m}$ & $\begin{array}{l}\mathrm{Wt}(\mathrm{g}) \\
\Delta \mathrm{Wt}(\mathrm{g}) \\
\Delta \mathrm{Wt}(\%) \\
\text { Length } \\
\Delta \text { Length } \\
\Delta \text { Length (\%) }\end{array}$ & \begin{tabular}{r|}
413.53 \\
12.47 \\
3.1 \\
1183 \\
145 \\
14.0 \\
\end{tabular} & $\begin{array}{r}422.88 \\
9.56 \\
2.3 \\
1232 \\
151 \\
14.0 \\
\end{array}$ & $\begin{array}{r}421.63 \\
13.74 \\
3.4 \\
1042 \\
157 \\
17.7 \\
\end{array}$ & $\begin{array}{r}419.17 \\
13.28 \\
3.3 \\
1054 \\
150 \\
16.6 \\
\end{array}$ & \begin{tabular}{r|}
410.35 \\
10.28 \\
2.6 \\
1208 \\
141 \\
13.2 \\
\end{tabular} & $\begin{array}{r}413.21 \\
9.22 \\
2.3 \\
1128 \\
160 \\
16.5 \\
\end{array}$ & $\begin{array}{r}415.01 \\
13.09 \\
3.3 \\
1113 \\
150 \\
15.6 \\
\end{array}$ & +2.9 avg \\
\hline
\end{tabular}


Table 5.12 Length and weight change for specimens cured in $\mathrm{Ca}(\mathrm{OH})_{2}$.

\begin{tabular}{|c|c|c|c|c|c|c|c|c|}
\hline & & \multicolumn{6}{|c|}{ Sample Number } & \\
\hline & & 15 & 16 & 17 & 18 & 19 & 20 & \\
\hline To & $\mathrm{Wt}(\mathrm{g})$ & 411.4 & 402.53 & 406.17 & 403.29 & 416.1 & 402.53 & \\
\hline 2/8/2005 & length & 1240 & 1176 & 1049 & 1125 & 1057 & 967 & \\
\hline $28 d$ cure & Wt (g) & 411.6 & 402.99 & 406.62 & 403.32 & 415.77 & 402.41 & \\
\hline $3 / 1 / 2005$ & length & 1167 & 1112 & 975 & 1048 & 962 & 896 & \\
\hline 1 month & Wt $(g)$ & 418.2 & 412.78 & 416.26 & 412.28 & 422 & 412.68 & \\
\hline & $\Delta \mathrm{Wt}(\mathrm{g})$ & 6.67 & 9.79 & 9.64 & 8.96 & 6.23 & 10.27 & \\
\hline & $\Delta \mathrm{Wt}(\%)$ & 1.6 & 2.4 & 2.4 & 2.2 & 1.5 & 2.6 & $+2.1 \%$ avg \\
\hline & length & 1240 & 1179 & 1049 & 1120 & 1045 & 970 & \\
\hline & $\Delta$ length & 73 & 67 & 74 & 72 & 83 & 74 & \\
\hline & $\Delta$ length(\%) & 6.3 & 6.0 & 7.6 & 6.9 & 8.6 & 8.3 & $+7.3 \%$ avg \\
\hline $3 \mathrm{~m}$ & $\mathrm{Wt}(\mathrm{g})$ & 420.2 & 414.62 & 418.2 & 414.42 & 423.85 & 414.52 & \\
\hline & $\Delta \mathrm{Wt}(\mathrm{g})$ & 8.65 & 11.63 & 11.58 & 11.1 & 8.08 & 12.11 & \\
\hline & $\Delta \mathrm{Wt}(\%)$ & 2.1 & 2.9 & 2.8 & 2.8 & 1.9 & 3.0 & $+2.6 \%$ avg \\
\hline & length & 1268 & 1198 & 1073 & 1147 & 1075 & 998 & \\
\hline & $\Delta$ length & 101 & 86 & 98 & 99 & 113 & 102 & \\
\hline & $\Delta$ length $(\%)$ & 8.7 & 7.7 & 10.1 & 9.4 & 11.7 & 11.4 & $+9.8 \%$ avg \\
\hline $6 \mathrm{~m}$ & $\mathrm{Wt}(\mathrm{g})$ & 423.2 & 417.43 & 421.19 & 416.23 & 427.39 & 418.07 & \\
\hline & $\Delta \mathrm{Wt}(\mathrm{g})$ & 11.65 & 14.44 & 14.57 & 12.91 & 11.62 & 15.66 & \\
\hline & $\Delta \mathrm{Wt}(\%)$ & 2.8 & 3.6 & 3.6 & 3.2 & 2.8 & 3.9 & $+3.3 \%$ avg \\
\hline & length & 1285 & 1227 & 1089 & 1156 & 1094 & 1018 & \\
\hline & $\Delta$ length & 118 & 115 & 114 & 108 & 132 & 122 & \\
\hline & $\Delta$ length $(\%)$ & 10.1 & 10.3 & 11.7 & 10.3 & 13.7 & 13.6 & $+11.6 \%$ avg \\
\hline $9 \mathrm{~m}$ & Wt $(g)$ & 424.4 & 419.15 & 422.53 & 418.06 & 428.4 & 419.15 & \\
\hline & $\Delta \mathrm{Wt}(\mathrm{g})$ & 12.89 & 16.16 & 15.91 & 14.74 & 12.63 & 16.74 & \\
\hline & $\Delta \mathrm{Wt}(\%)$ & 3.1 & 4.0 & 3.9 & 3.7 & 3.0 & 4.2 & $+3.7 \%$ avg \\
\hline & length & 1299 & 1241 & 1100 & 1170 & 1104 & 1029 & \\
\hline & $\Delta$ length & 132 & 129 & 125 & 122 & 142 & 133 & \\
\hline & $\Delta$ length $(\%)$ & 11.3 & 11.6 & 12.8 & 11.6 & 14.8 & 14.8 & $+12.8 \%$ avg \\
\hline $12 \mathrm{~m}$ & Wt (g) & 424.1 & 418.84 & 422.21 & 418.22 & 428.45 & 419.29 & \\
\hline & $\Delta \mathrm{Wt}(\mathrm{g})$ & 12.57 & 15.85 & 15.59 & 14.9 & 12.68 & 16.88 & \\
\hline & $\Delta \mathrm{Wt}(\%)$ & 3.1 & 3.9 & 3.8 & 3.7 & 3.0 & 4.2 & $+3.6 \%$ avg \\
\hline & length & 1304 & 1247 & 1111 & 1178 & 1109 & 1038 & \\
\hline & $\Delta$ length & 137 & 135 & 136 & 130 & 147 & 142 & \\
\hline & $\Delta$ length $(\%)$ & 11.7 & 12.1 & 13.9 & 12.4 & 15.3 & 15.8 & $+13.6 \%$ avg \\
\hline $18 \mathrm{~m}$ & Wt (g) & 424.54 & 419.22 & 422.68 & 418.65 & 428.87 & 419.71 & \\
\hline & $\Delta \mathrm{Wt}(\mathrm{g})$ & 12.99 & 16.23 & 16.06 & 15.33 & 13.1 & 17.3 & \\
\hline & $\Delta \mathrm{Wt}(\%)$ & 3.2 & 4.0 & 3.9 & 3.8 & 3.2 & 4.3 & +3.7 avg \\
\hline & $\Delta$ length & 1232 & 1254 & 1129 & 1194 & 1126 & 1054 & \\
\hline & $\Delta$ Length & 156 & 142 & 154 & 146 & 164 & 158 & \\
\hline & $\Delta$ Length $(\%)$ & 13.4 & 12.8 & 15.8 & 13.9 & 17.0 & 17.6 & $+15.1 \%$ avg \\
\hline
\end{tabular}

solution show a slight increase in weight gain relative to the specimens conditioned in the $\mathrm{Na}_{2} \mathrm{HPO}_{4}$ solution. Some of the differences in weight change can be attributed to differences in the propensity of the solutions to form crystals on the specimen's surfaces (e.g., specimens conditioned in the $\mathrm{MgHPO}_{4}$ 
solution tended to also form carbonate crystals). The larger gain of weight for the samples kept in the $\mathrm{Ca}(\mathrm{OH})_{2}$ solution is probably due to the large amount of calcium carbonate deposits present on the surfaces of the specimens. The variation observed on the chart is confirmed by the visual observations of carbonate growth on the specimen's surfaces. Individual weight change results are also presented in Tables 5.10 to 5.12 for samples cured in $\mathrm{Na}_{2} \mathrm{HPO}_{4}, \mathrm{MgHPO}_{4}$, and $\mathrm{Ca}(\mathrm{OH})_{2}$, respectively.

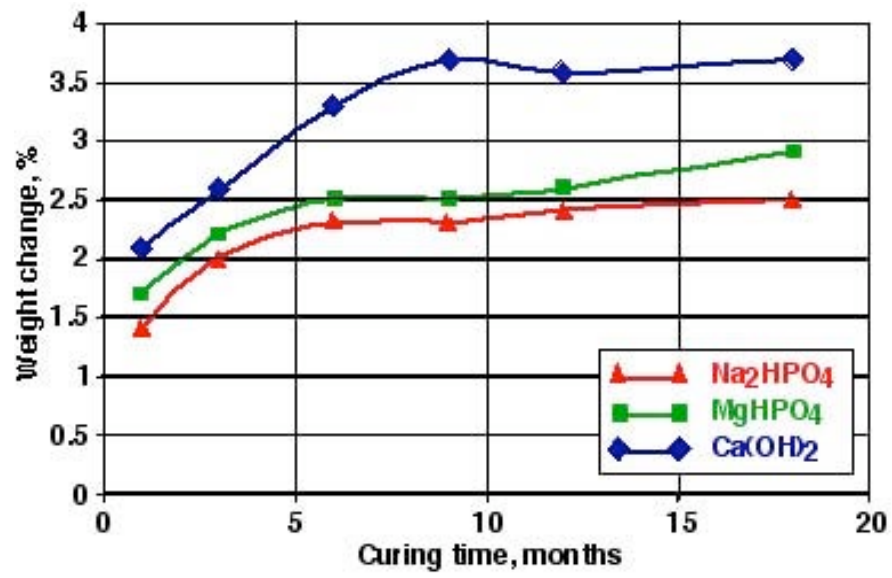

Figure 5.48 Comparison of weight change results as function of time - 18 month results

Three specimens each were tested in compression after 18-months of curing in the solutions. The results obtained are presented in Figure 5.49. The average value and error bar associated with each average

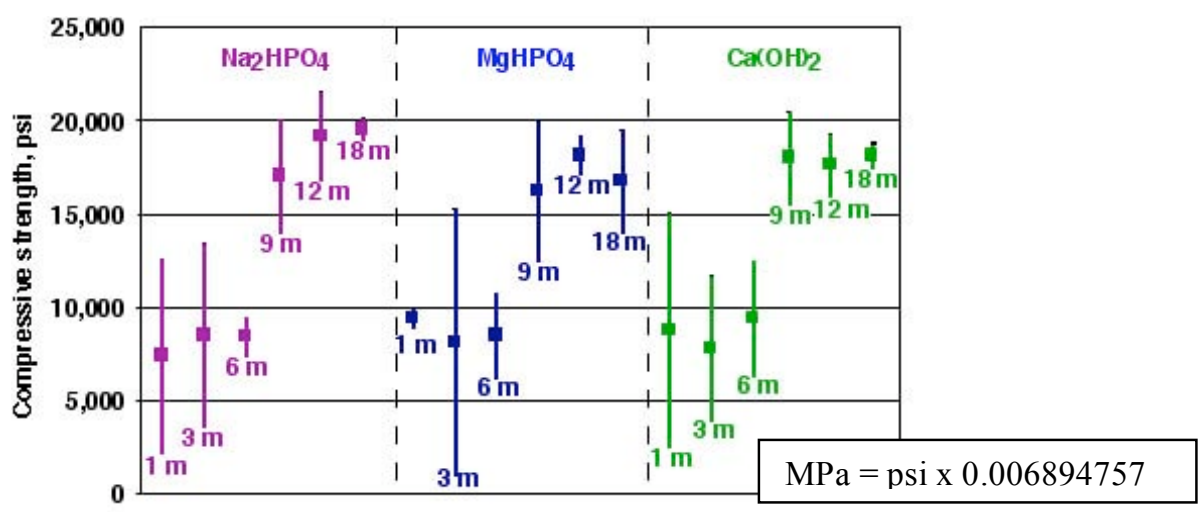

Figure 5.49 Effect of curing period on compressive strength of 2-in.-cube specimens.

result are also shown in the figure. For some results, primarily early in the test program, the error bar is wide; this is usually caused when a defect is present in one specimen (e.g., air bubble). Due to the limited number of tests for each curing solution at each of the curing times, a statistical evaluation of the measurements did not allow removing any measured value as an outlier. As noted in the figure, the compressive strength values obtained after 18 months cure were high, between 16,000 and 20,000 psi $(110$ to $138 \mathrm{MPa})$ for specimens cured in each of the three solutions. Figure 5.49 shows that the compressive strengths have increased consistently since the beginning of the test, 18 months ago. If the phosphate solutions were having a deleterious affect on the cement past specimens, it would be expected that the compressive strength would decrease with increasing exposure period which is opposite to what has been observed. The actual data utilized to prepare these figures is found in Tables 5.13 to 5.15 for samples cured in $\mathrm{Ca}(\mathrm{OH})_{2}, \mathrm{Na}_{2} \mathrm{HPO}_{4}$, and $\mathrm{MgHPO}_{4}$, respectively. 
Table 5.13 Compressive strength results for specimens cured in $\mathrm{Ca}(\mathrm{OH})_{2}$ for periods up to 18 months $(\mathrm{MPa}=$ psi $x \mathbf{0 . 0 0 6 8 9 4 7 5 7})$

\begin{tabular}{|c|c|c|}
\hline & 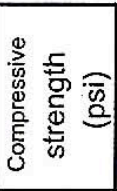 & 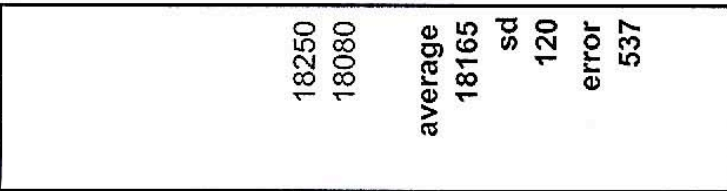 \\
\hline & 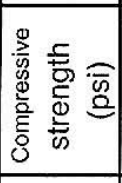 & 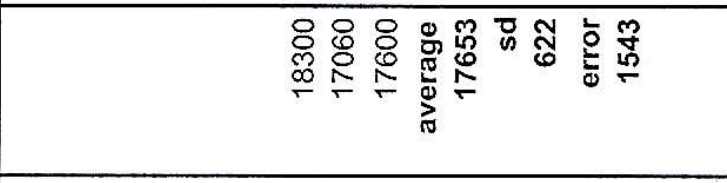 \\
\hline$\stackrel{\mathrm{N}}{\simeq}$ & $\overline{3} \widehat{0}$ & 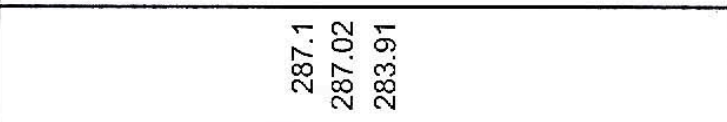 \\
\hline & 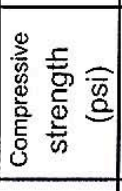 & 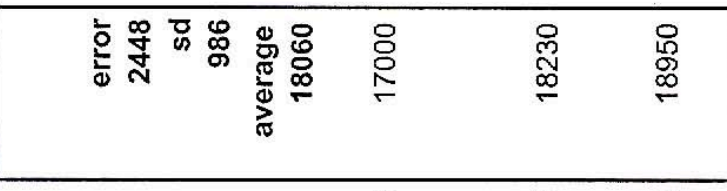 \\
\hline & $\xi \hat{\theta}$ & 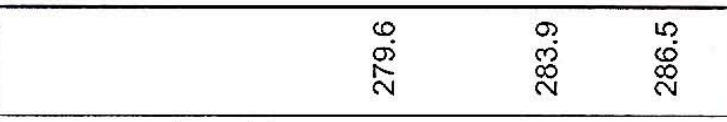 \\
\hline & 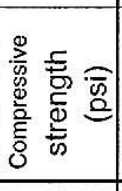 & 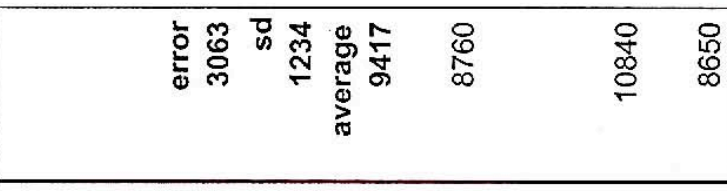 \\
\hline & 芝可 & 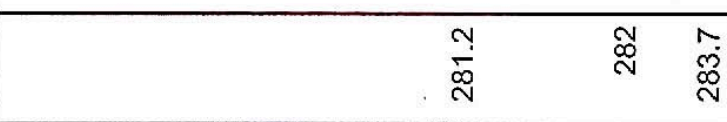 \\
\hline & 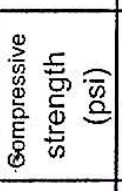 & 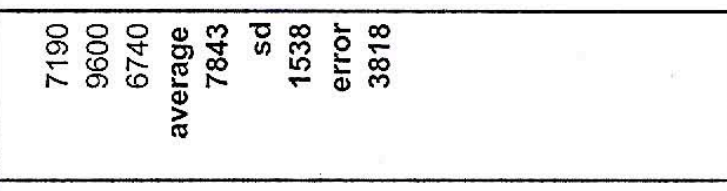 \\
\hline$=1$ & त्र & 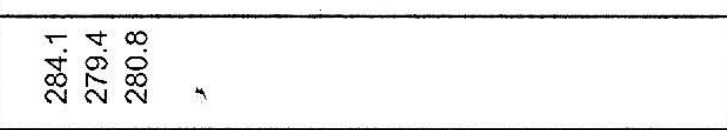 \\
\hline & \begin{tabular}{|c|c|}
0 \\
0
\end{tabular} & 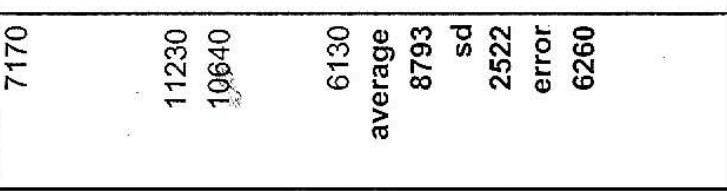 \\
\hline & 节 & 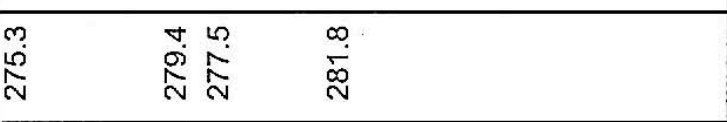 \\
\hline & 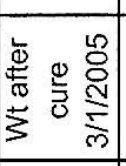 & 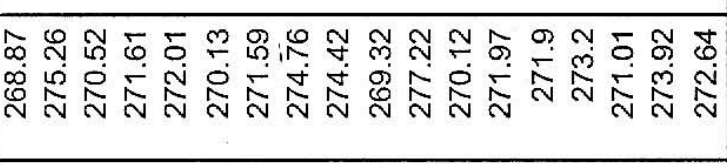 \\
\hline & 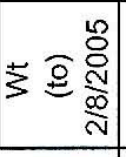 & 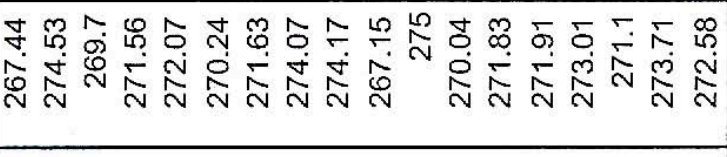 \\
\hline & & 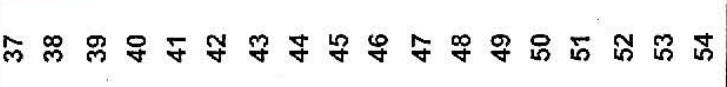 \\
\hline
\end{tabular}


Table 5.14 Compressive strength results for specimens cured in $\mathrm{Na}_{2} \mathrm{HPO}_{4}$ for periods up to18 months $(\mathrm{MPa}=$ psi $x \mathbf{0 . 0 0 6 8 9 4 7 5 7})$

\begin{tabular}{|c|c|c|}
\hline 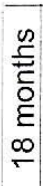 & 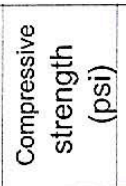 & 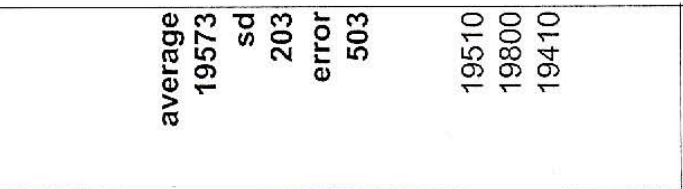 \\
\hline & 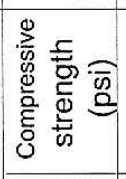 & 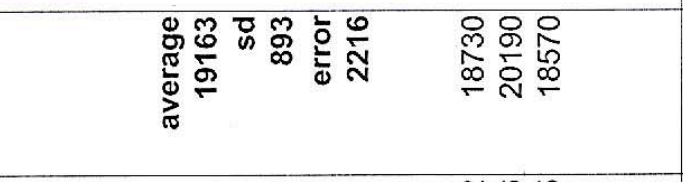 \\
\hline$\stackrel{c}{\stackrel{c}{\sim}}$ & उ्ञ & +2 \\
\hline & 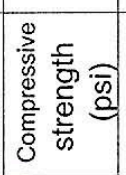 & 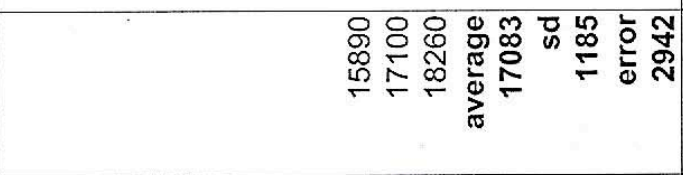 \\
\hline $\begin{array}{c}\varepsilon \\
\sigma\end{array}$ & इ & 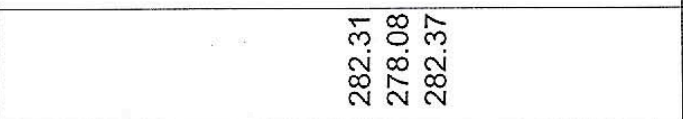 \\
\hline & 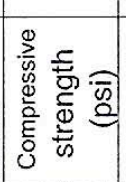 & 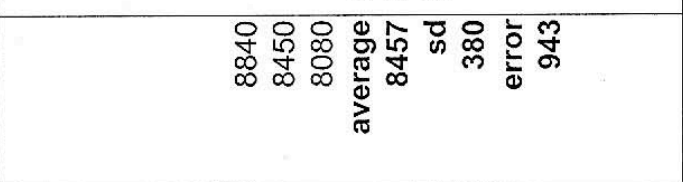 \\
\hline $\begin{array}{c}\varepsilon \\
\emptyset\end{array}$ & 可 & 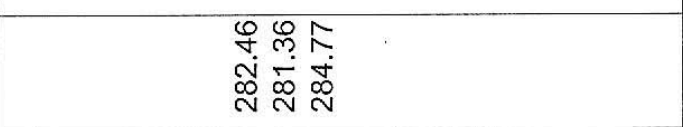 \\
\hline & 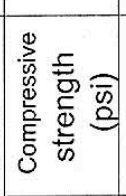 & 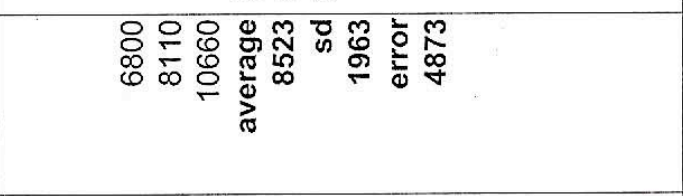 \\
\hline $\begin{array}{ll}\xi \\
m\end{array}$ & इ이 & 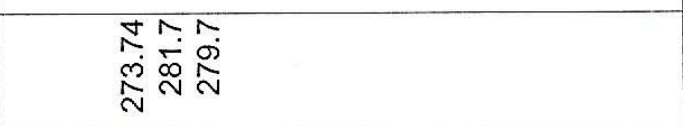 \\
\hline 동 & 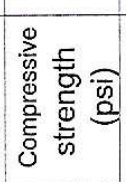 & 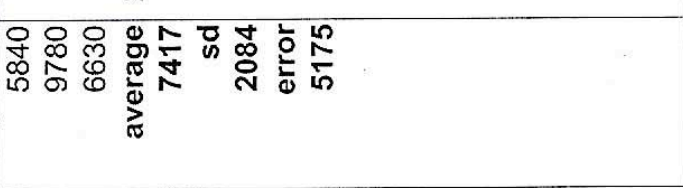 \\
\hline$\frac{\varepsilon}{r}$ & इ이 & 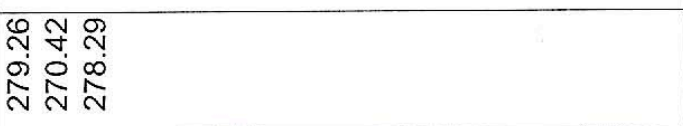 \\
\hline \multirow{3}{*}{ 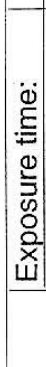 } & 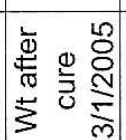 & 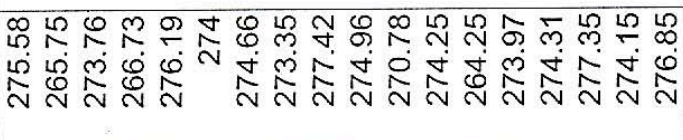 \\
\hline & 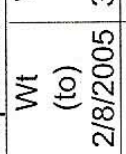 & 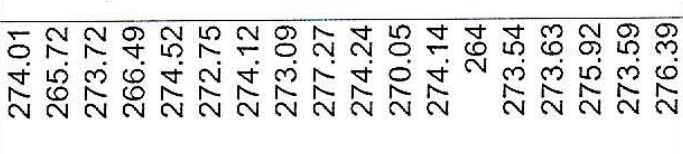 \\
\hline & & 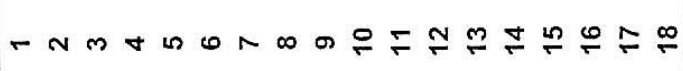 \\
\hline
\end{tabular}


Table 5.15 Compressive strength results for specimens cured in $\mathrm{MgHPO}_{4}$ for periods up to 18 months $(\mathrm{MPa}=$ psi $x \mathbf{0 . 0 0 6 8 9 4 7 5 7})$

\begin{tabular}{|c|c|c|}
\hline & 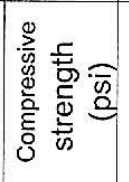 & 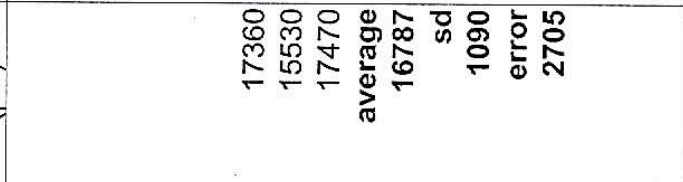 \\
\hline & 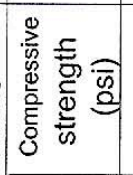 & 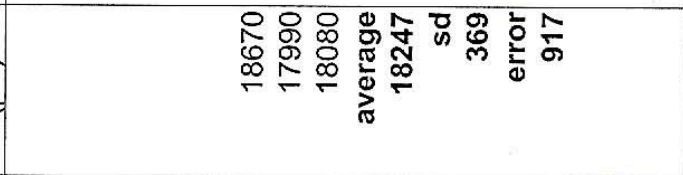 \\
\hline$\stackrel{N}{\sim}$ & 菏 & 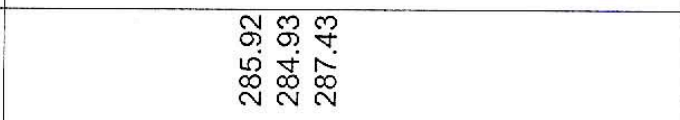 \\
\hline & 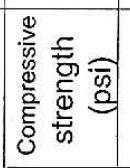 & 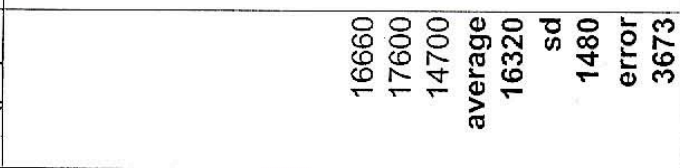 \\
\hline ๘) & इ क् & 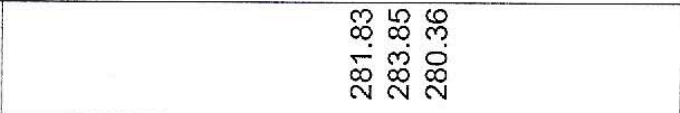 \\
\hline & 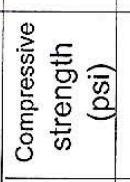 & 흉 \\
\hline $\begin{array}{c}\varepsilon \\
6\end{array}$ & 芌 & 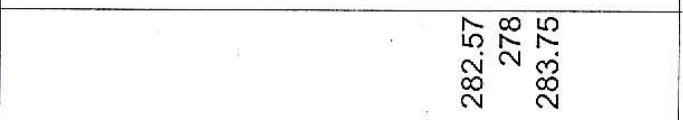 \\
\hline & 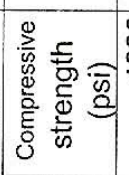 & 品 : \\
\hline $\begin{array}{c}\xi \\
m\end{array}$ & 宁 क्ञ & 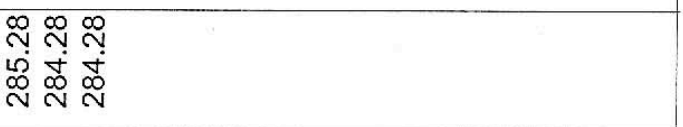 \\
\hline 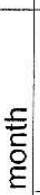 & 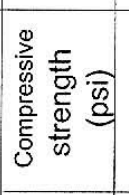 & 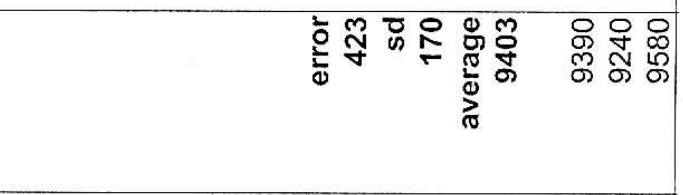 \\
\hline 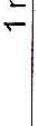 & 亏 & 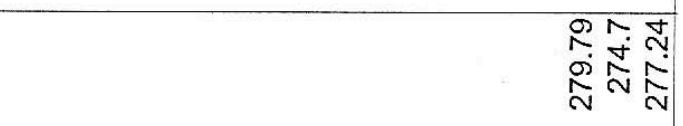 \\
\hline & 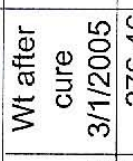 & 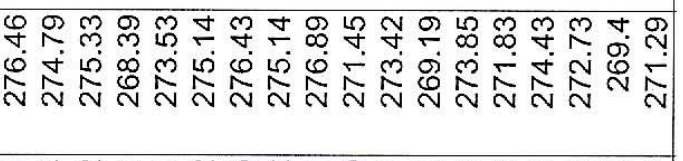 \\
\hline & 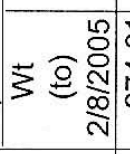 & 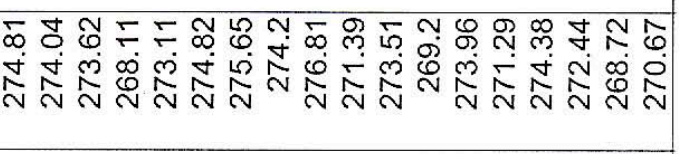 \\
\hline & & 유 \\
\hline
\end{tabular}




\subsubsection{X-ray Diffraction Results}

Two samples per specimen were prepared for each curing condition. The first sample was collected from the outer surface of the specimen by scraping the surface with a scalpel. The thickness of this layer is estimated to be approximately two hundred microns. The second sample was also obtained near the outside layer of the prism, but had a thickness of about 5-8 $\mathrm{mm}$. A comparison of the spectra obtained at the two depths is thus used to determine if penetration of the phosphate salts occurred to create new mineral phases. The spectra obtained from the four samples cured in the phosphate solutions are shown in Figure 5.50. As one can see, the spectra contain many peaks with most of them overlapping thus

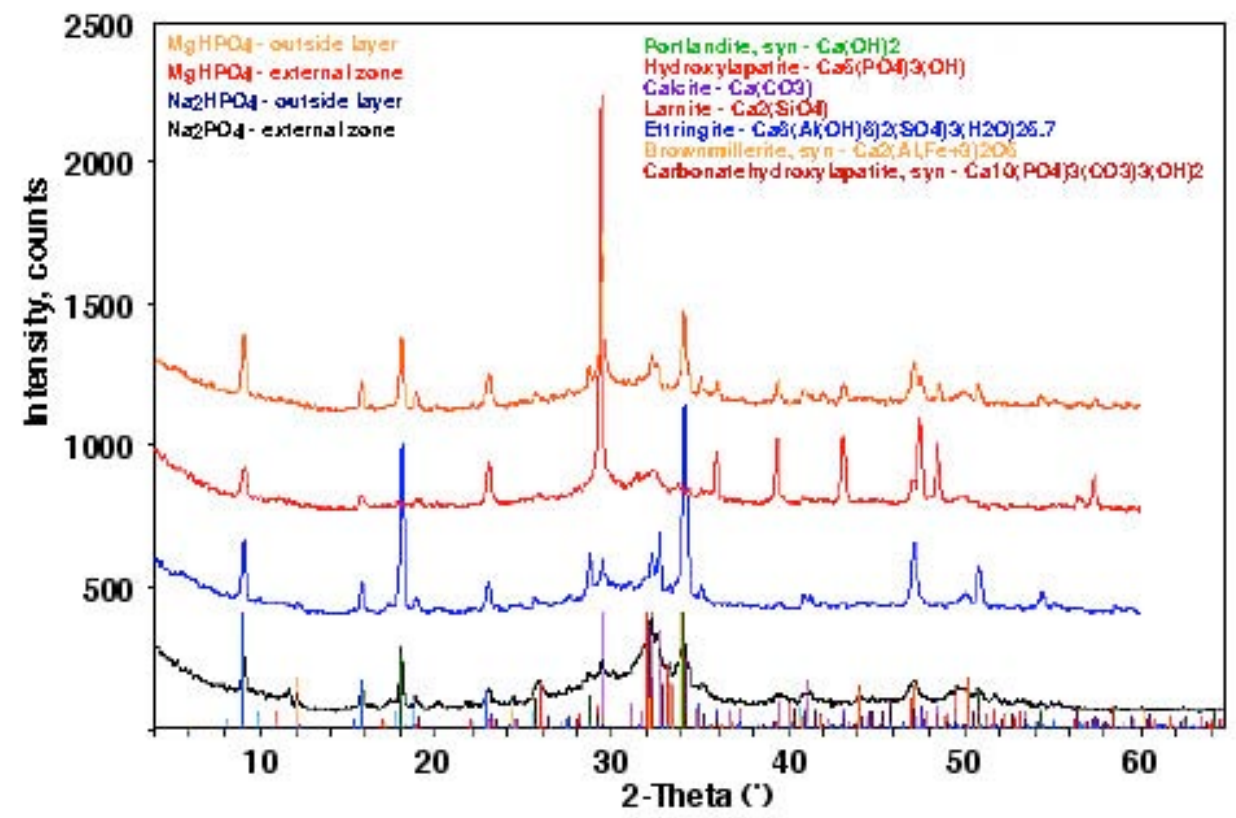

Figure 5.50 XRD spectrum from samples cured in phosphate solutions for 18 months.

making identification of the mineral phases present difficult. The main mineral phases identified in all four sprectra are: Ettringite $\left(\mathrm{Ca}_{6}\left(\mathrm{Al}(\mathrm{OH})_{6}\right)_{2}\left(\mathrm{SO}_{4}\right)_{3}\left(\mathrm{H}_{2} \mathrm{O}\right)_{25.7}\right)$, Portlandite $\left(\mathrm{Ca}(\mathrm{OH})_{2}\right)$, Calcite $\left(\mathrm{CaCO}_{3}\right)$, Brownmillerite $\left[\mathrm{Ca}_{2}\left(\mathrm{Al}, \mathrm{Fe}^{+3}\right)_{2} \mathrm{O}_{5}\right]$, and Larnite $\left(\mathrm{Ca}_{2} \mathrm{SiO}_{4}\right)$. The peaks for hydroxylapatite $\left[\mathrm{Ca}_{5}\left(\mathrm{PO}_{4}\right)_{3}(\mathrm{OH})\right]$ and carbonatehydroxylapatite $\left[\mathrm{Ca}_{10}\left(\mathrm{PO}_{4}\right)_{3}\left(\mathrm{CO}_{3}\right)(\mathrm{OH})_{2}\right]$ cannot be identified with certainty. The spectra obtained for the first 200 microns (external zone) show that calcite is very abundant, as would be expected in this layer, while Portlandite is less abundant than identified in the outside layers of the samples (external layer).

In order to reduce the complexity of the spectra, a selective dissolution of the calcium silicate phases was performed using techniques described elsewhere. ${ }^{40,64.65}$ This well known method is used for determination of the compositions of phases in clinkers and cements, and appears to be applicable to hydrated cements. The technique involved mixing one gram of each ground sample for 30 minutes in a beaker with 9 grams of salicylic acid and $35 \mathrm{~mL}$ of methanol. After filtration and rinsing of the residue, the material was dried at $80^{\circ} \mathrm{C}$ for 24 hours, and then analyzed by XRD. The extraction removed $78 \%$ of the original material for the specimen cured in $\mathrm{Na}_{2} \mathrm{HPO}_{4}$ and $72 \%$ for the specimen cured in $\mathrm{MgHPO}_{4}$. Comparable numbers can be found in the literature.

Figures 5.51 and 5.52 present the XRD spectra for the original sample and the sample after dissolution of the calcium silicate phases by salicylic acid for the $\mathrm{MgHPO}_{4}$ and $\mathrm{Na}_{2} \mathrm{HPO}_{4}$ cured specimens, respectively. The peaks for hydroxyapatite and carbonatehydroxyapatite are definitely seen. Other phases possibly 
present for the sample cured in $\mathrm{MgHPO}_{4}$ include: Brucite $\left(\mathrm{Mg}(\mathrm{OH})_{2}\right)$, Calcium sulfate hydrate $\left(\mathrm{CaSO}_{4}\right.$ !0.67 $\left.\mathrm{H}_{2} \mathrm{O}\right)$, Calcite $\left(\mathrm{Ca}(\mathrm{CO})_{3}\right)$ and Lizardite $1 \mathrm{M}\left[(\mathrm{Mg}, \mathrm{Fe})_{3} \mathrm{Si}_{2} \mathrm{O}_{5}(\mathrm{OH})_{4}\right]$. For the sample cured in $\mathrm{Na}_{2} \mathrm{HPO}_{4}$ the following phases were identified as possibly being present: Brushite $\left[\mathrm{CaHPO}_{4}\left(\mathrm{H}_{2} \mathrm{O}\right)_{2}\right]$, calcium sulfate hydrate $\left(\mathrm{CaSO}_{4} ! 0.67 \mathrm{H}_{2} \mathrm{O}\right)$, Brucite $\left[\mathrm{Mg}(\mathrm{OH})_{2}\right]$, and Lizardite $1 \mathrm{~T}\left(\mathrm{Mg}_{2.70} \mathrm{Fe}_{0.18}\right.$ $\left.\mathrm{Al}_{0.11}\right)\left(\mathrm{Si}_{1.81} \mathrm{Al}_{0.19} \mathrm{O}_{5}\right)(\mathrm{OH})_{4}$.

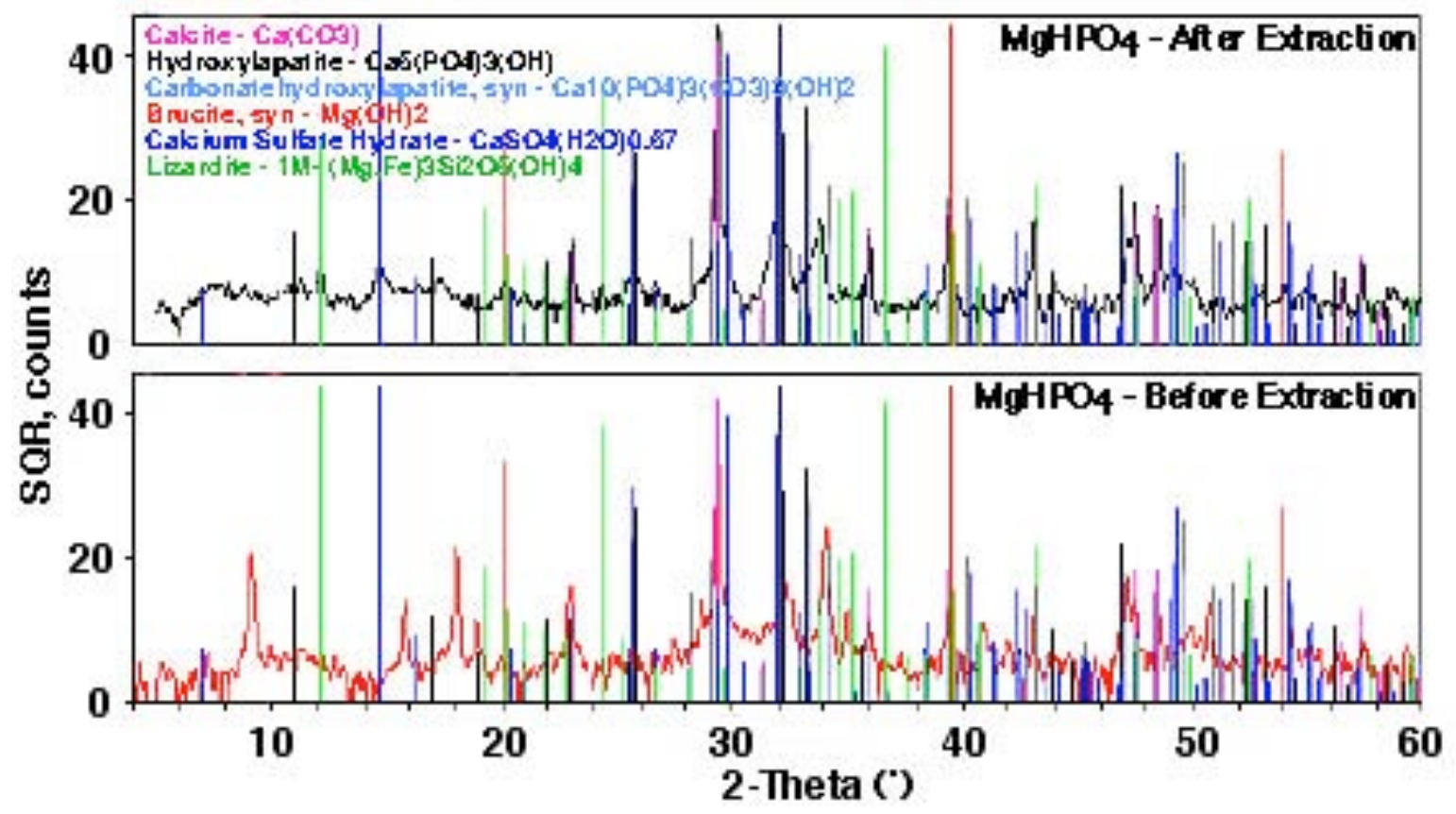

Figure 5.51 XRD spectrum of specimen cured in $\mathrm{MgHPO}_{4}$ before and after extraction by salicylic acid.

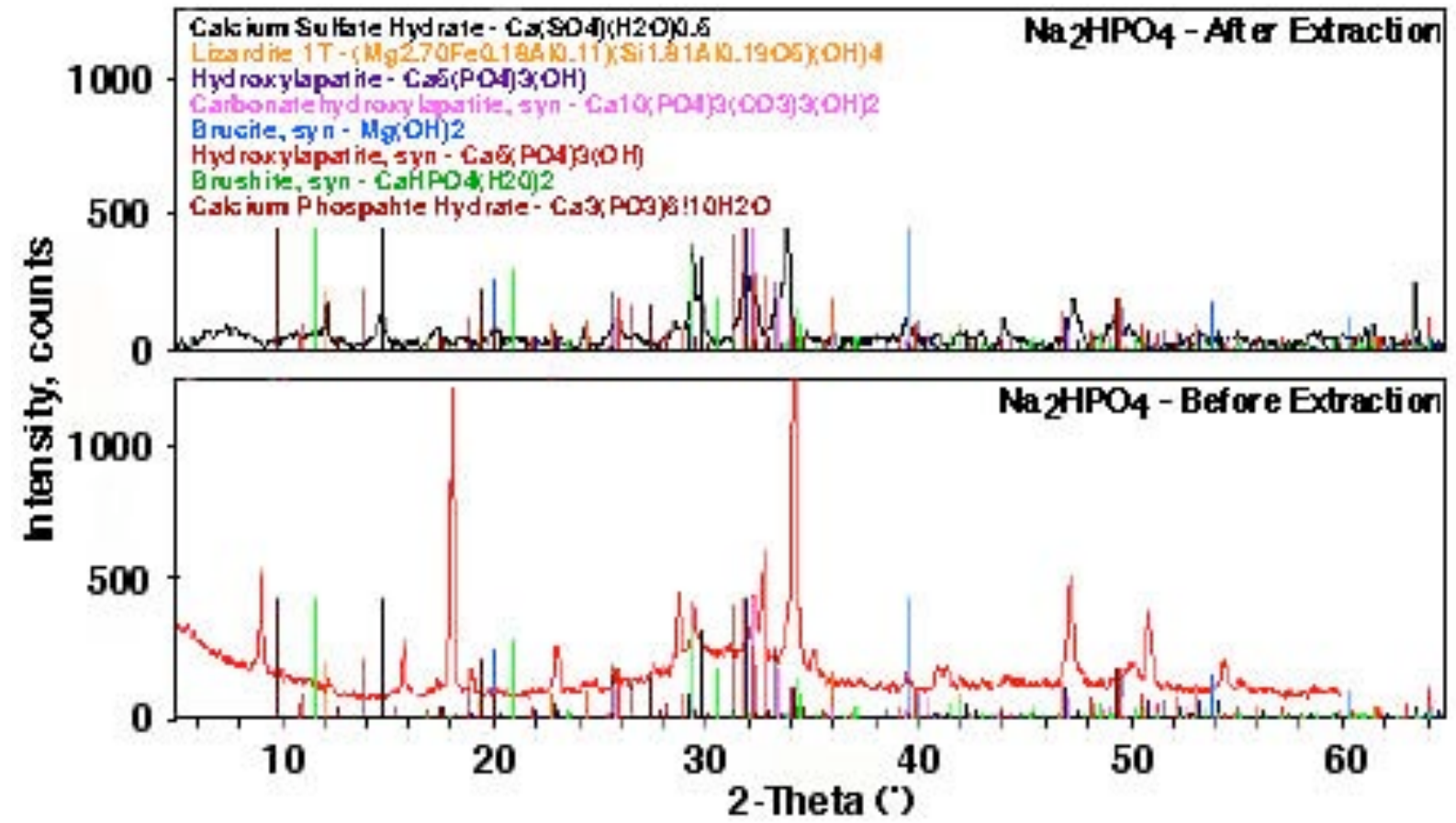

Figure 5.52 XRD spectrum of specimen cured in $\mathrm{Na}_{2} \mathrm{HPO}_{4}$ before and after extraction by salicylic acid. 
To investigate more completely the effect of phosphate salts (magnesium and sodium) on cementitious materials, an accelerated bench scale test was conducted. The purpose of this test was to determine if the effect of phosphate on a fresh cement paste and an older structure was the same. A Type V Portland cement sample and a sample obtained from a hydrated Type I-II Portland cement specimen that had been curing in $\mathrm{Ca}(\mathrm{OH})_{2}$ saturated solution for 12 months were utilized. The samples were dried and ground to pass a $120 \mu \mathrm{m}$ sieve. The samples were ground to accelerate the rate of reactions by creating more surface area in contact with the solutions.

Two solutions were prepared, a saturated $\mathrm{MgHPO}_{4} \cdot 3 \mathrm{H}_{2} \mathrm{O}$ solution containing about $74 \mathrm{mg} / \mathrm{L}$ of magnesium and $300 \mathrm{mg} / \mathrm{L}$ of phosphate $\left(\mathrm{PO}_{4}\right)$ and a non-saturated (because of the very high saturation concentration) solution of $\mathrm{Na}_{2} \mathrm{HPO}_{4} \cdot 7 \mathrm{H}_{2} \mathrm{O}$ containing about $7000 \mathrm{mg} / \mathrm{L}$ of sodium and $7500 \mathrm{mg} / \mathrm{L}$ of phosphate $\left(\mathrm{PO}_{4}\right)$. To serve as a "control" for the test, the same solids were tested with a saturated solution of $\mathrm{Ca}(\mathrm{OH})_{2}$ and underwent the same preparation. For each test, 10 grams of the solid powder was mixed with $100 \mathrm{~mL}$ of each solution and rotated at a speed of $30 \mathrm{rpm}$. Samples were taken after 7 and 14 days of tumbling. The liquid and solid phases were separated by centrifugation.

Analysis of the solutions - initial and after mixing with the solids - was made by inductively coupled plasma - atomic emission spectroscopy (ICP-AES) using a Thermo-Jarrell Ash model 61E Trace instrument for the cations and by colorimetry using a Hach colorimeter for phosphate. The latter instrument provides only semi-quantitative results, but was judged sufficient for these measurements. After drying, the solids were analyzed by XRD to identify the phases formed.

As shown in Table 5.16, the samples cured in $\mathrm{Na}_{2} \mathrm{HPO}_{4}$ solution contained less barium, calcium, strontium, and silicon than the reference sample cured in $\mathrm{Ca}(\mathrm{OH})_{2}$ (Table 5.18); however, the concentration of potassium is comparable to the reference. This illustrates that the normal set of the cement is not taking place. In the case of the samples cured in $\mathrm{MgHPO}_{4}$, the results found in Table 5.17 show that the concentrations for all elements are comparable to the reference. This observation could mean that the set is not as disturbed by the magnesium-phosphate salt as it is with the sodium-phosphate salt.

Table 5.16 Analyses (in mg/L) of the $\mathrm{Na}_{2} \mathrm{HPO}_{4}$ solution before and after contact with anhydrous or hydrated Portland cement

\begin{tabular}{|l|c|c|c|c|c|}
\hline & $\begin{array}{c}\text { Mother } \\
\text { solution: } \\
\mathbf{N a}_{2} \mathbf{H P O}_{4}\end{array}$ & $\begin{array}{c}\text { Type V } \\
\text { Portland } \\
\text { cement after } \\
\text { 7-days } \\
\text { exposure }\end{array}$ & $\begin{array}{c}\text { Type V } \\
\text { Portland } \\
\text { cement after } \\
\text { 14-days } \\
\text { exposure }\end{array}$ & $\begin{array}{c}\text { 12 month } \\
\text { aged cement } \\
\text { paste after 7- } \\
\text { days } \\
\text { exposure }\end{array}$ & $\begin{array}{c}\text { 12 month } \\
\text { aged cement } \\
\text { paste after } \\
\text { 14-days } \\
\text { exposure }\end{array}$ \\
\hline Aluminum & 6 & 7.6 & 7.5 & 7.1 & 8.7 \\
\hline Baruim & 0.8 & 0.8 & 0.8 & 0.8 & 0.8 \\
\hline Calcium & 77 & 75 & 89 & 94 & 125 \\
\hline Potassium & 20 & 329 & 345 & 241 & 253 \\
\hline Magnesium & 5 & 5 & 5 & 5 & 5 \\
\hline Sodium & 6700 & 6400 & 6500 & 6400 & 6700 \\
\hline Silicon & 10.9 & 11.6 & 6.7 & 4 & 9.3 \\
\hline Strontium & 4 & 4 & 4 & - & 4 \\
\hline $\begin{array}{l}\text { Phosphate as } \\
\text { PO }\end{array}$ & 7900 & 0 & 0 & 0 & 0 \\
\hline
\end{tabular}


Table 5.17 Analyses (in $\mathrm{mg} / \mathrm{L}$ ) of the $\mathrm{MgHPO}_{4}$ solution before and after contact with anhydrous or hydrated Portland cement

\begin{tabular}{|l|c|c|c|c|c|}
\hline & $\begin{array}{c}\text { Mother } \\
\text { solution: } \\
\text { MgHPO }\end{array}$ & $\begin{array}{c}\text { Type V } \\
\text { Portland } \\
\text { cement after } \\
\text { 7-days } \\
\text { exposure }\end{array}$ & $\begin{array}{c}\text { Type V } \\
\text { Portland } \\
\text { cement after } \\
\text { 14-days } \\
\text { exposure }\end{array}$ & $\begin{array}{c}\text { 12 month } \\
\text { aged cement } \\
\text { paste after 7- } \\
\text { days } \\
\text { exposure }\end{array}$ & $\begin{array}{c}\text { 12 month } \\
\text { aged cement } \\
\text { paste after } \\
\text { 14-days } \\
\text { exposure }\end{array}$ \\
\hline Aluminum & 6 & 6.3 & 6 & 6 & 6 \\
\hline Baruim & 0.8 & 7.8 & 9 & 6.6 & 6.6 \\
\hline Calcium & 32 & 831 & 832 & 919 & 821 \\
\hline Potassium & 20 & 333 & 351 & 212 & 215 \\
\hline Magnesium & 74 & 5 & 5 & 5 & 5 \\
\hline Sodium & 15 & 88 & 92 & 103 & 104 \\
\hline Silicon & 4.5 & 15.2 & 3.1 & 7.9 & 3.5 \\
\hline Strontium & 4 & 16 & 16.7 & 20 & 21.3 \\
\hline $\begin{array}{l}\text { Phosphate as } \\
\text { PO }\end{array}$ & 300 & 0 & 0 & 0 & 0 \\
\hline
\end{tabular}

Table 5.18 Analyses (in $\mathrm{mg} / \mathrm{L}$ ) of the $\mathrm{Ca}(\mathrm{OH})_{2}$ solution before and after contact with anhydrous or hydrated Portland cement.

\begin{tabular}{|c|c|c|c|c|}
\hline $\begin{array}{c}\text { Mother } \\
\text { solution: } \\
\text { Ca(OH) }\end{array}$ & $\begin{array}{c}\text { Type V } \\
\text { Portland } \\
\text { cement after } \\
\text { 7-days } \\
\text { exposure }\end{array}$ & $\begin{array}{c}\text { Type V } \\
\text { Portland } \\
\text { cement after } \\
\text { 14-days } \\
\text { exposure }\end{array}$ & $\begin{array}{c}\text { 12 month } \\
\text { aged cement } \\
\text { paste after 7- } \\
\text { days } \\
\text { exposure }\end{array}$ & $\begin{array}{c}\text { 12 month } \\
\text { aged cement } \\
\text { paste after 14- } \\
\text { days exposure }\end{array}$ \\
\hline Aluminum & 1.2 & 6 & 6 & 6 \\
\hline Baruim & 7.8 & 8.9 & 6.6 & 6.7 \\
\hline Calcium & 835 & 811 & 855 & 853 \\
\hline Potassium & 349 & 310 & 207 & 215 \\
\hline Magnesium & 2.7 & 5 & 5 & 5 \\
\hline Sodium & 81 & 85 & 101 & 106 \\
\hline Silicon & 0.8 & 5.5 & 5.9 & 4.9 \\
\hline Strontium & 15.6 & 16.5 & 20.3 & 21.9 \\
\hline
\end{tabular}

The same extraction procedure was used on some additional samples to remove calcium silicates to help recognize the mineral phases present. Figure 5.53 presents the spectra obtained for the anhydrous cement or the one-year paste exposed to the $\mathrm{Na}_{2} \mathrm{HPO}_{4}$ solution. Again the complexity of the spectra does not allow the formal identification of the phosphate phases. Phases that can be identified for the samples cured in $\mathrm{Na}_{2} \mathrm{HPO}_{4}\left(\right.$ Figure 5.53) are Portlandite $\left[\mathrm{Ca}(\mathrm{OH})_{2}\right]$, Ettringite $\left[\mathrm{Ca}_{6}\left(\mathrm{Al}(\mathrm{OH})_{6}\right)_{2}\left(\mathrm{SO}_{4}\right)_{3}\left(\mathrm{H}_{2} \mathrm{O}\right)_{25.7}\right]$, $\mathrm{C}-\mathrm{S}-\mathrm{H}\left(\mathrm{Ca}_{1.5} \mathrm{Si}_{3.5}\right.$ ! $\left.\mathrm{xH}_{2} \mathrm{O}\right)$, and $\mathrm{CaCO}_{3}$. The samples prepared using the one-year hydrated cement paste also show the presence of Kuzelite $\left(\mathrm{Ca}_{4} \mathrm{Al}_{2}(\mathrm{SO})_{4}(\mathrm{OH})_{12}-6 \mathrm{H}_{2} \mathrm{O}\right)$ and Kuzelite-mono $\left[\mathrm{Ca}_{2} \mathrm{Al}(\mathrm{OH})_{6}\right)\left(\mathrm{S}_{0.50} \mathrm{O}_{2}\left(\mathrm{OH}_{2}\right)_{3}\right]$, carbonate aluminates $\left(\mathrm{Ca}_{8} \mathrm{Al}_{4} \mathrm{O}_{14} \mathrm{CO}_{2}-24 \mathrm{H}_{2} \mathrm{O}\right)$ and Laumontite $\left(\mathrm{C}_{4} \mathrm{Al}_{8} \mathrm{Si}_{16} \mathrm{O}_{48}-16 \mathrm{H}_{2} \mathrm{O}\right)$. The peaks for hydroxylapatite or carbonatehydroxylapatite are difficult to confirm due to overlapping. After dissolution of the calcium silicates the presence of these two phases as well as possibly calcium sulfate hydrate $\left[\mathrm{CaSO}_{4}\left(\mathrm{H}_{2} \mathrm{O}\right)_{0.67}\right]$ was confirmed as seen in Figure 5.54. 


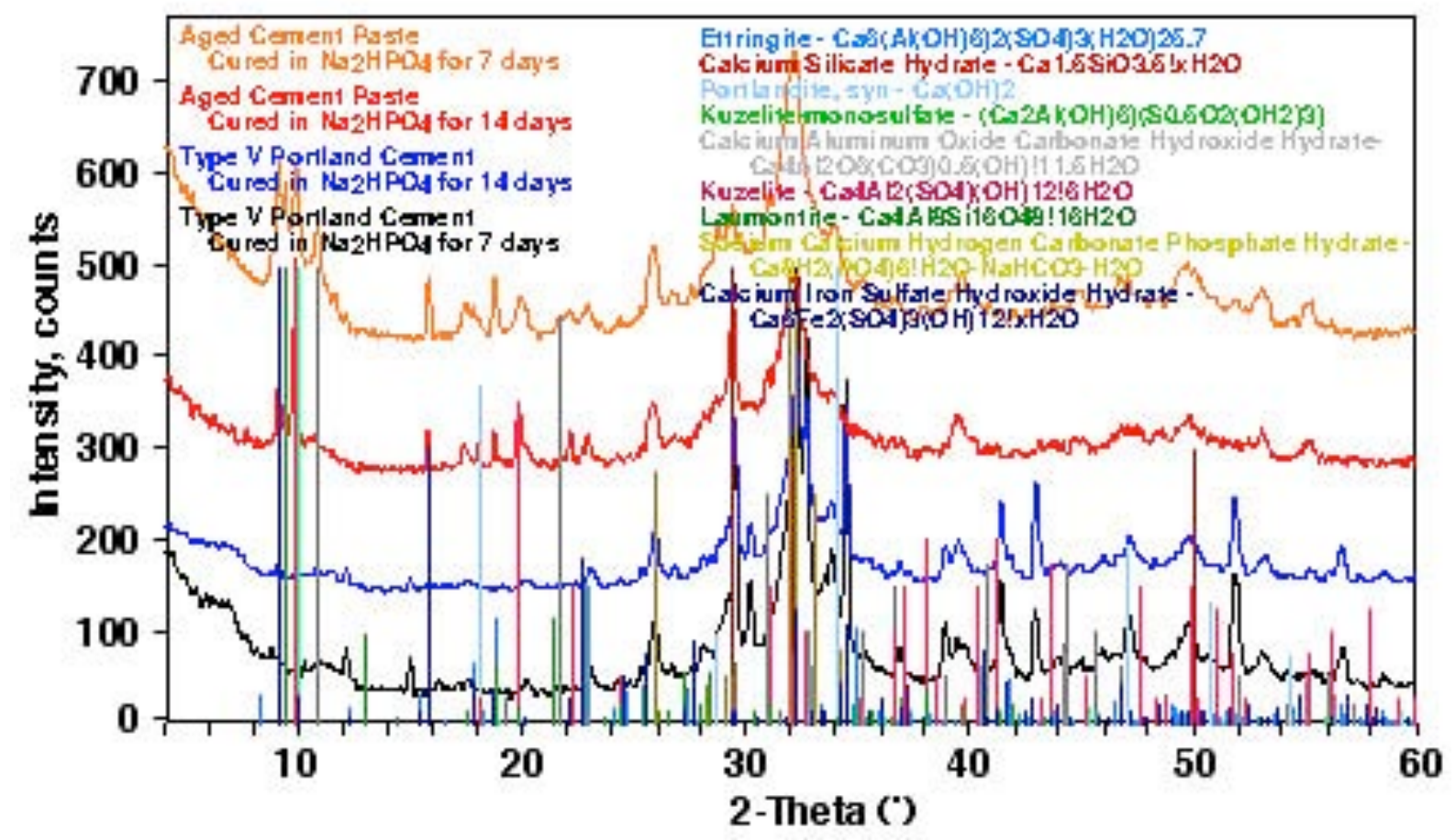

Figure 5.53 Main phases present in samples cured in $\mathrm{Na}_{2} \mathrm{HPO}_{4}$ solution.

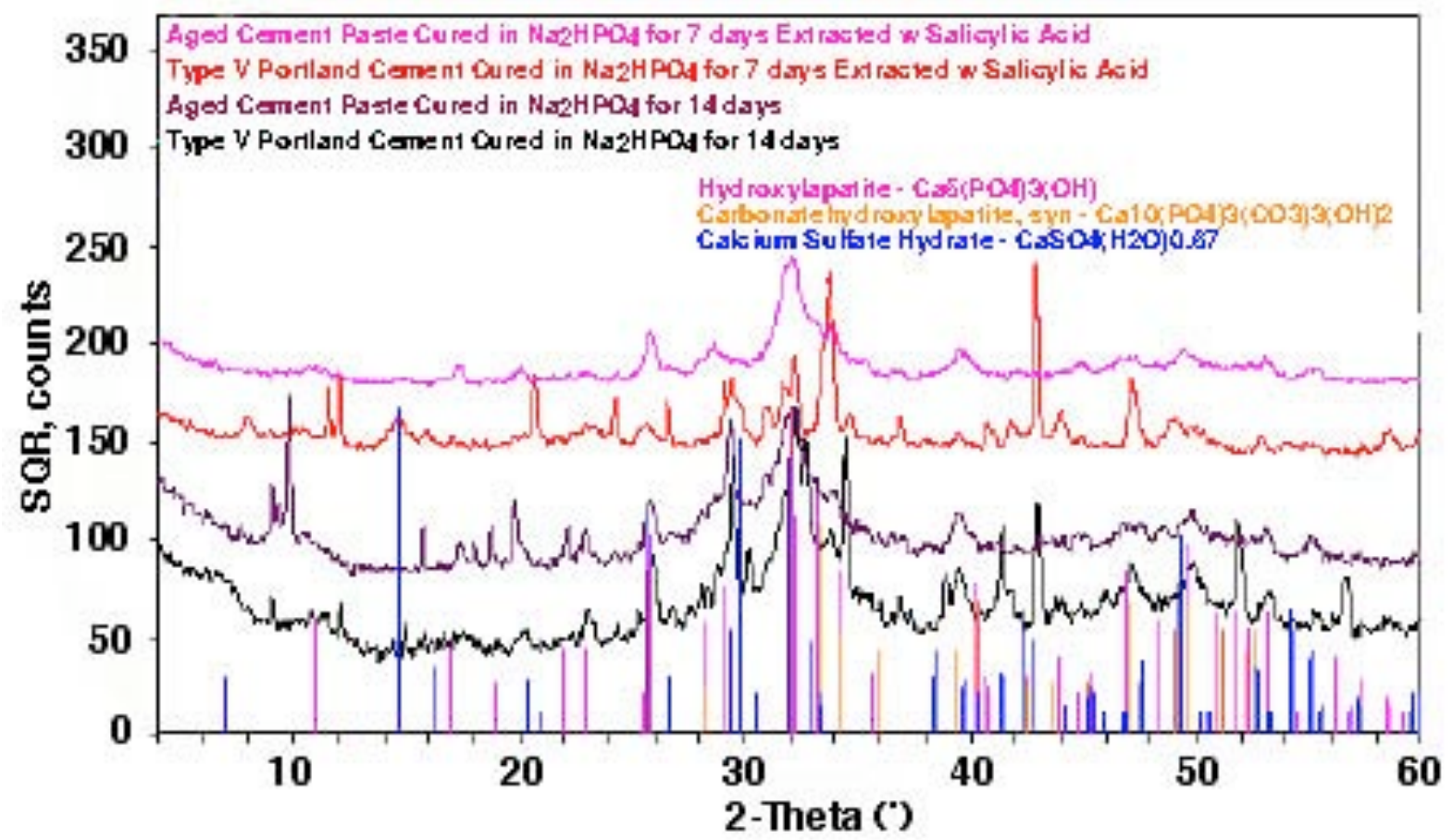

Figure 5.54 Minor phases present in samples cured in $\mathrm{Na}_{2} \mathrm{HPO}_{4}$ solution. 
The phases identified for the samples cured in $\mathrm{MgHPO}_{4}$ (Figure 5.55) are Portlandite $\left[\mathrm{Ca}(\mathrm{OH})_{2}\right]$, Ettringite $\left[\mathrm{Ca}_{6}\left(\mathrm{Al}(\mathrm{OH})_{6}\right)_{2}\left(\mathrm{SO}_{4}\right)_{3}\left(\mathrm{H}_{2} \mathrm{O}\right)_{25.7}\right]$, C-S-H $\left(\mathrm{Ca}_{1.5} \mathrm{Si}_{3.5} ! \mathrm{xH}_{2} \mathrm{O}\right)$, and $\mathrm{CaCO}_{3}$. The samples prepared

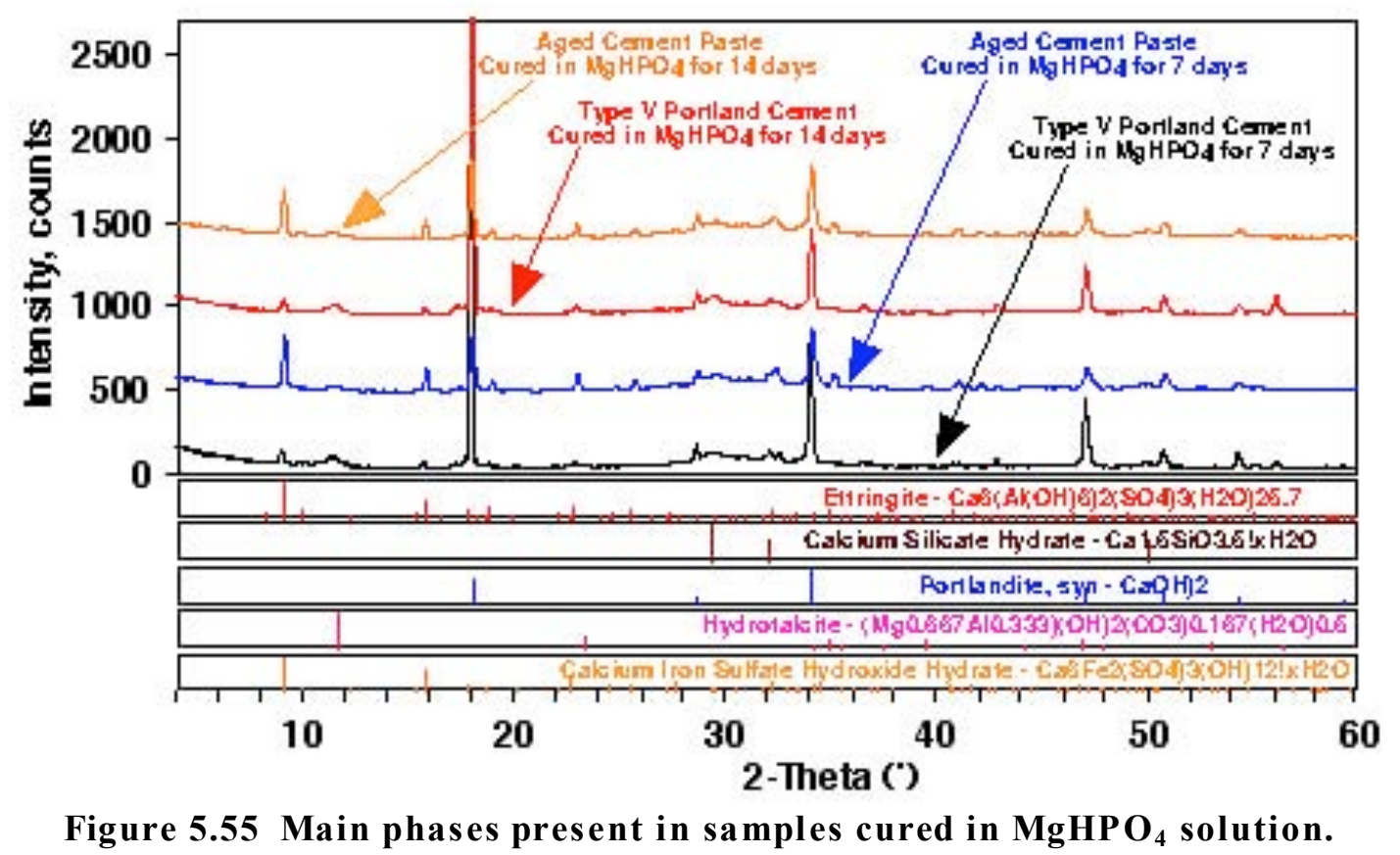

with the aged hydrated cement paste also show the presence of Kuzelite-monosulfate $\left[\mathrm{Ca}_{2} \mathrm{Al}(\mathrm{OH})_{6}\right)\left(\mathrm{S}_{0.50} \mathrm{O}_{2}\left(\mathrm{OH}_{2}\right)_{3}\right]$ and possibly calcium iron sulfate hydroxide hydrate $\left[\mathrm{Ca}_{6} \mathrm{Fe}_{2}\left(\mathrm{SO}_{4}\right)_{3}(\mathrm{OH})_{12} ! \mathrm{xH}_{2} \mathrm{O}\right]$. The samples fabricated from Portland cement could also possibly contain clinotobermorite $\left[\mathrm{Ca}_{5}\left(\mathrm{Si}_{6} \mathrm{O}_{16}(\mathrm{OH})_{2}\right)\left(\mathrm{H}_{2} \mathrm{O}\right)_{4}\right]$. The presence of hydroxylapatite and carbonatehydroxylapatite was confirmed as well as the possible presence of calcium sulfate hydrate $\left[\mathrm{CaSO}_{4}\left(\mathrm{H}_{2} \mathrm{O}\right)_{0.67}\right]$ after the dissolution of the calcium silicates was completed (Figure 5.56).

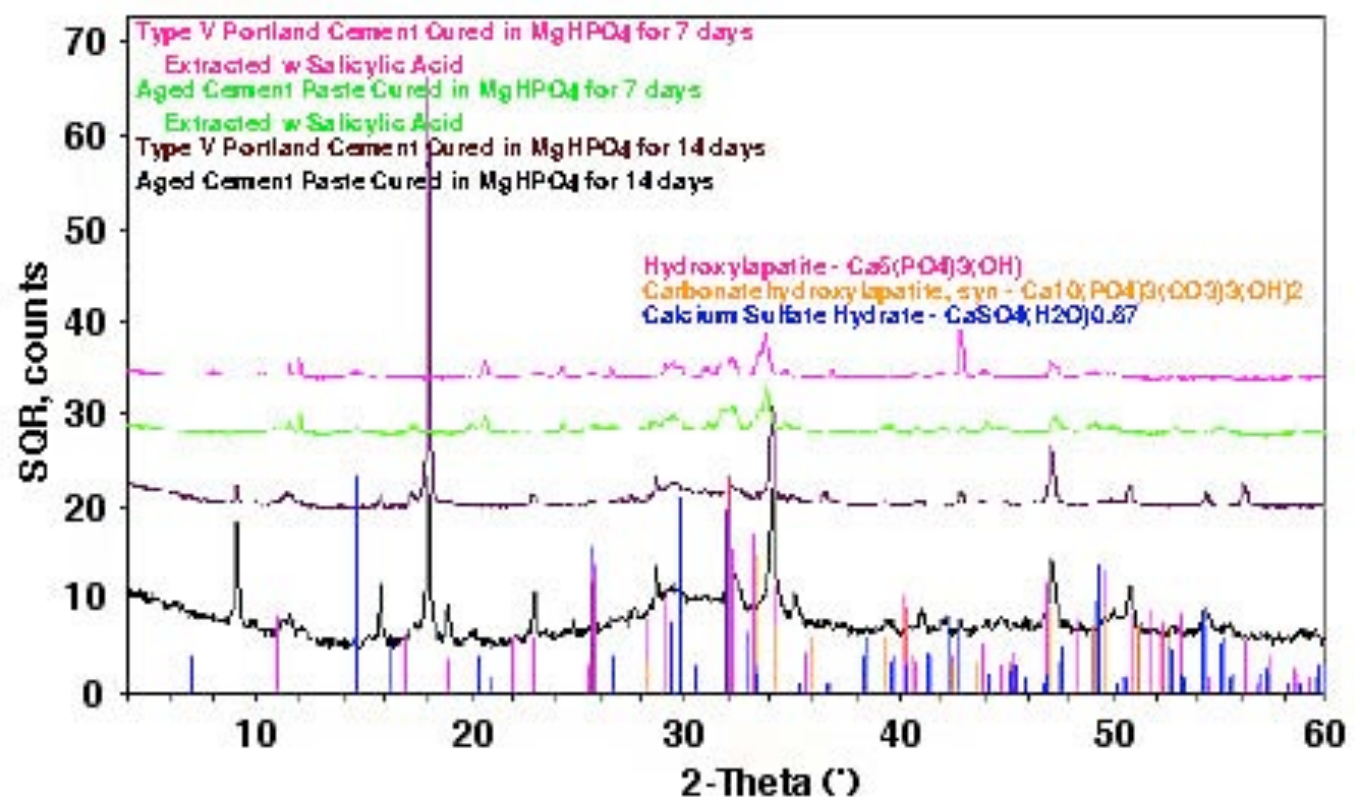

Figure 5.56 Minor phases present in samples cured in $\mathrm{MgHPO}_{4}$ solution. 


\subsubsection{SEM Examination Results}

The scanning-electron microscope (SEM) examinations performed on specimens after 18 months of conditioning in each of the solutions confirmed the results found by X-ray diffraction. As noted in Figure 5.57, the cement paste is very dense for the specimen cured in $\mathrm{Na}_{2} \mathrm{HPO}_{4}$. The outside layer does not exhibit much porosity. Crystals of Portlandite and sulfo-aluminates are visible in the figure. Phosphorus is present as seen on the EDX spectrum.
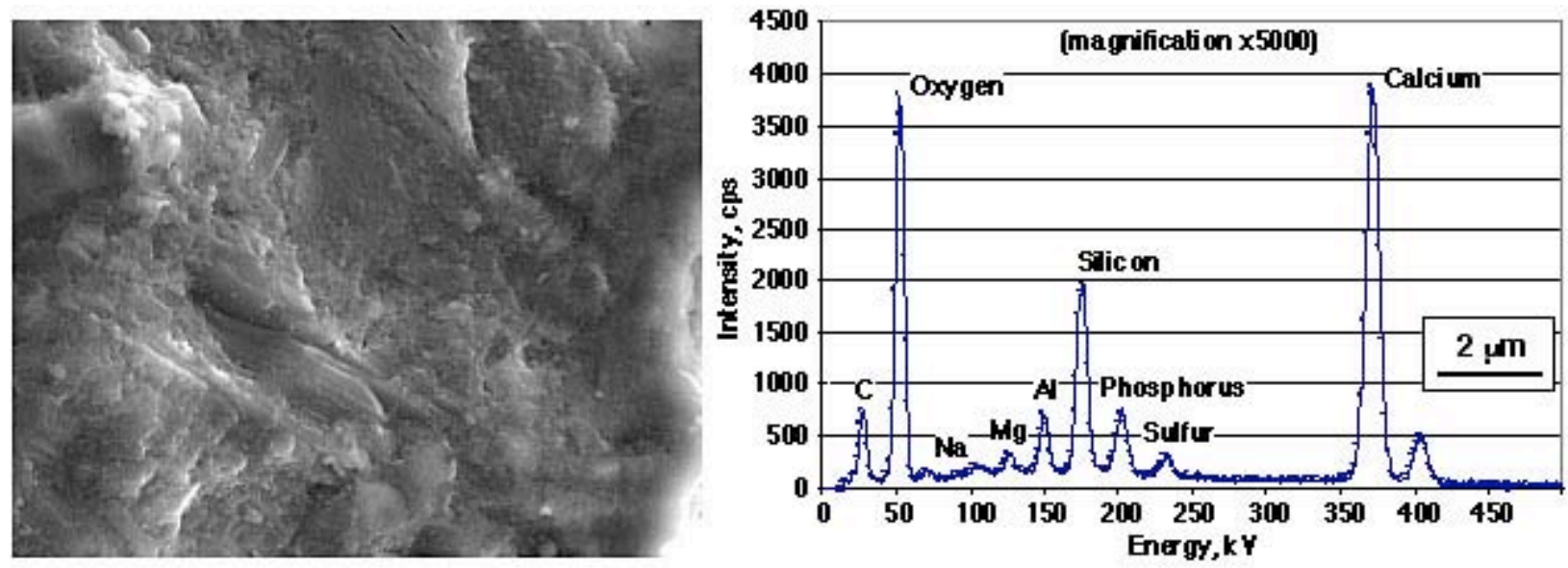

(a) Composition of entire ar ea
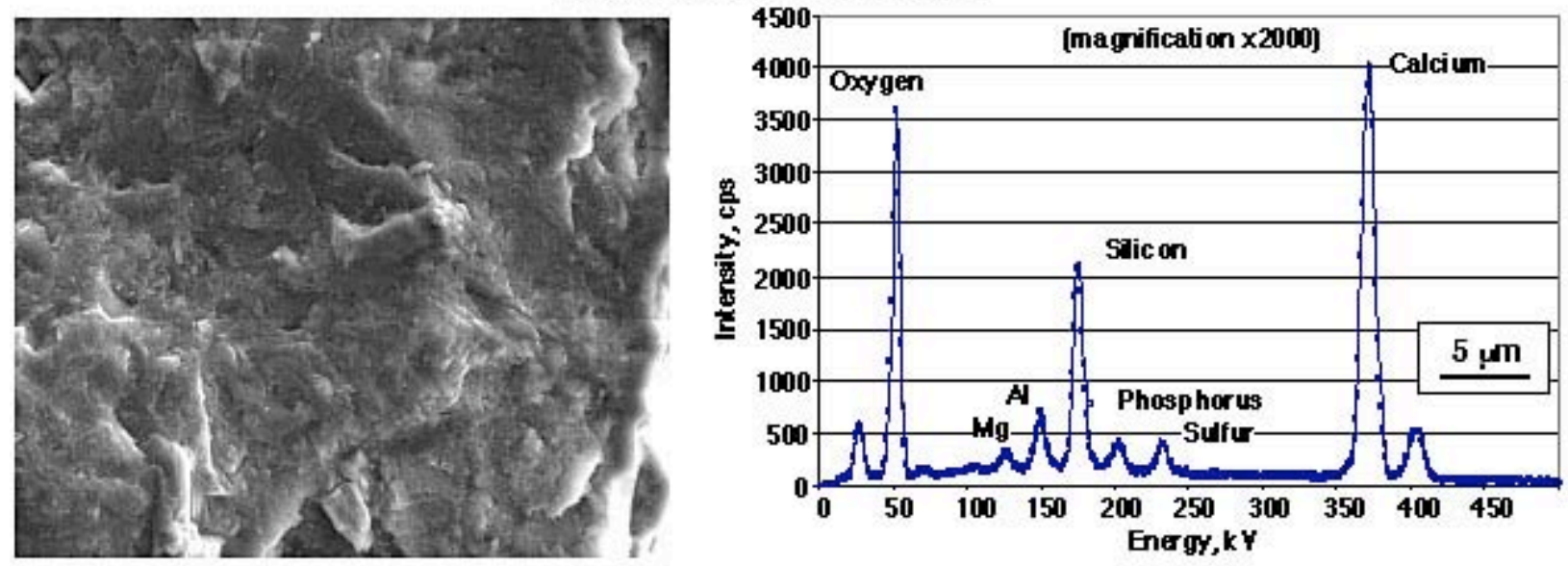

(b) Average composition of entire area

Figure 5.57 SEM of outside layer of sample cured in $\mathrm{Na}_{2} \mathrm{HPO}_{4}$.

Crystal forms of hydroxylapatite are difficult to identify in the dense paste and are probably finely mixed with the C-S-H; however, locally, as shown in Figure 5.58, one can find small areas that possibly contain minerals belonging to the hydroxylapatite family.

The border of the sample was examined in detail, but large formations of calcium phosphate were not found. It appears that the phosphorus present is mixed with other crystalline phases, probably the C-S-H as indicated elsewhere. ${ }^{34}$ Although rare, a well-crystallized calcium phosphate phase is seen inside a cement paste pore at the outside surface of the sample as shown in Figure 5.59. 


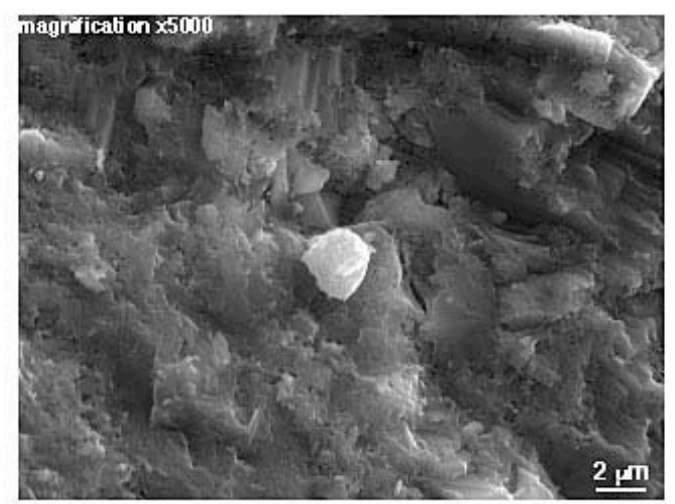

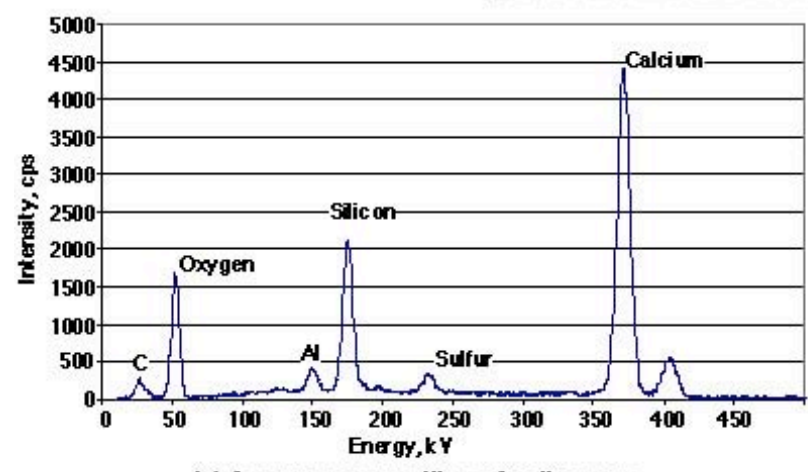

(a) Average composition of entire area

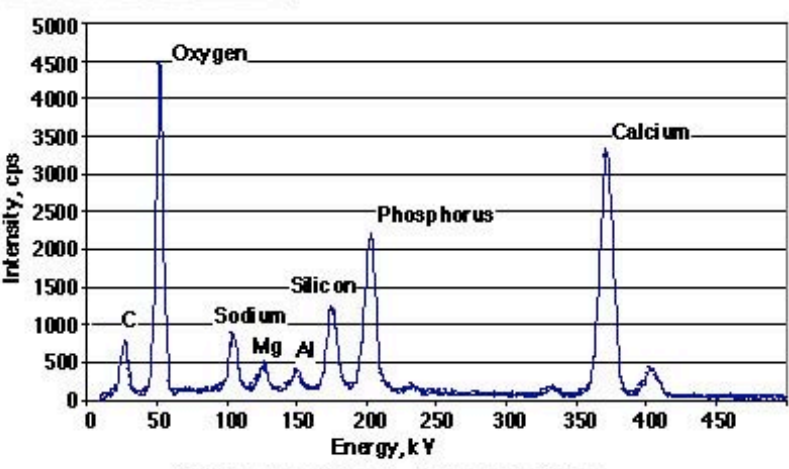

(b) Composition of white central area

Figure 5.58 Crystal containing calcium and phosphorus.
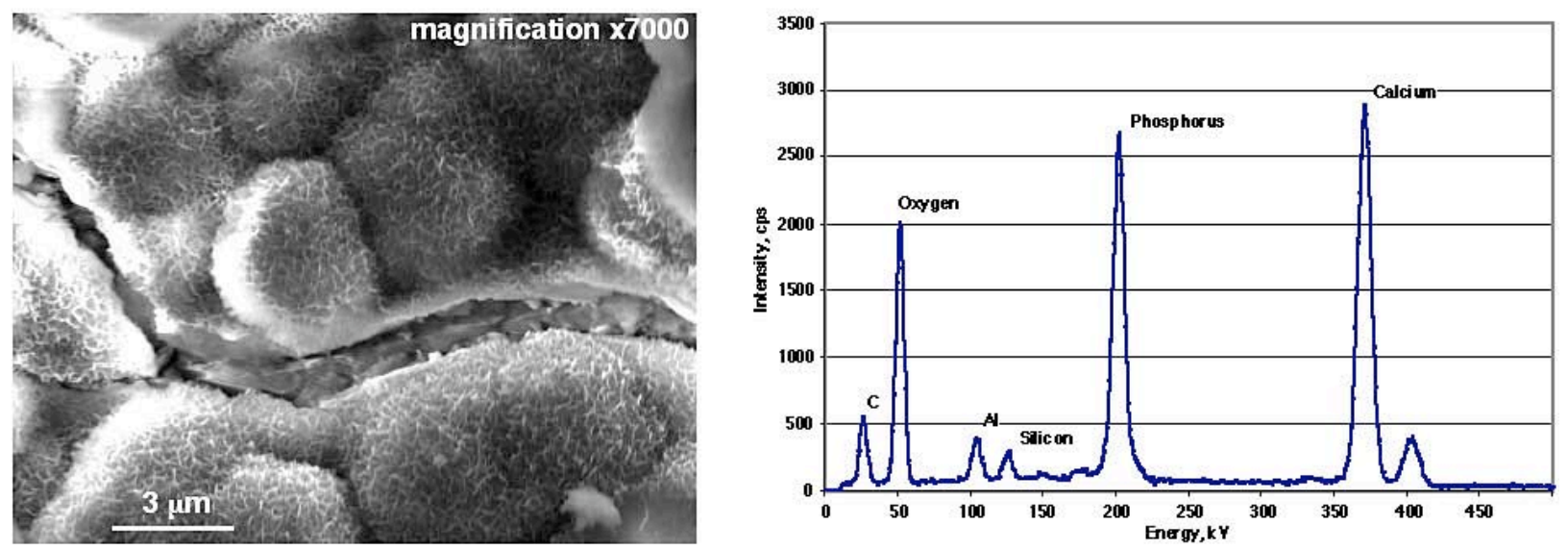

Figure 5.59 Crystals of calcium phosphate (possibly hydroxylapatite) found in cement paste pore near outside surface.

\subsubsection{Conclusions After Eighteen-Months Exposure}

After eighteen months of curing in saturated solutions of $\mathrm{Na}_{2} \mathrm{HPO}_{4}, \mathrm{MgHPO}_{4}$ or $\mathrm{Ca}(\mathrm{OH})_{2}$ (baseline), the cement paste specimens do not show any sign of deleterious reactions such as cracking and spalling. The specimens cured in the $\mathrm{Ca}(\mathrm{OH})_{2}$ solution are covered with carbonate crystals, but the specimens cured in $\mathrm{Na}_{2} \mathrm{HPO}_{4}$ are free of any deposits. The physical testing showed a decrease in length expansion for the specimens cured in the $\mathrm{Na}_{2} \mathrm{HPO}_{4}$ solution when compared to the specimens cured in $\mathrm{Ca}(\mathrm{OH})_{2}$ while the 
specimens cured in the $\mathrm{MgHPO}_{4}$ solution exhibited the same expansion as the reference $\mathrm{Ca}(\mathrm{OH})_{2}$ solution. Weight changes exhibited the same pattern. Compressive strength results obtained were uniformly high [16,000 to 20,000 psi (110 to $138 \mathrm{MPa})$ ], independent of the particular curing solution. Results indicate no significant deleterious reactions resulting from up to 18-months cure in concentrations of phosphate ions much higher than would be normally experienced in service.

Analyses by XRD and SEM showed the presence of calcium phosphate (probably hydroxylapatite and carbonatehydroxylapatite) in the samples cured in phosphate solutions. The results from the thermodynamic calculations were predicting that the final hydration product would be hydroxylapatite and the tests performed showed the presence of this phase. Hydroxylapatite is very stable and highly insoluble; therefore, the durability of cement or concrete where insoluble hydroxylapatite has replaced the slightly soluble calcium hydroxide should equal or increase the concrete durability. 


\section{SUMMARY AND CONCLUSIONS}

\subsection{SUMMARY}

The objectives of this limited study were to: (1) review the potential for degradation of cementitious materials due to exposure to high concentrations of phosphate ions; (2) provide an improved understanding of any significant factors that may lead to a requirement to establish exposure limits for concrete structures exposed to soils or ground waters containing high levels of phosphate ions; (3) recommend, as appropriate, whether a limitation on phosphate ion concentration in soils or ground water is required to avoid degradation of concrete structures; and (4) provide a "primer" on factors that can affect the durability of concrete materials and structures in nuclear power plants." An assessment of the potential effects of phosphate ions on cementitious materials was made through conduct of thermodyamic calculations and a review of available kinetic results, a review of the literature, contacts with concrete research personnel, and conduct of a "bench-scale" laboratory investigation.

Thermodynamic calculations performed using Outokumpu's HSC Chemistry V5.11 code substantiate the results in Appendix A indicating that phosphate could replace calcium hydroxide $\left[\mathrm{Ca}(\mathrm{OH})_{2}\right]$ with calcium hydroxyapatite $\left[\mathrm{Ca}_{5}\left(\mathrm{PO}_{4}\right)_{3} \mathrm{OH}\right]$. Kinetic results presented in the literature indicate that in high or medium supersaturated solutions, formation of hydroxyapatite always seems to be preceded by the precipitation of one or more precursor phases. Homogeneous formation of hydroxyapatite even at low supersaturtion was never seen.

A review of the literature did not identify any pertinent information relative to interaction of phosphate ions and cementitious materials. Where phosphate was present and degradation of concrete occurred, this was generally due to phosphate being in the form of phosphoric acid which is known to cause degradation of Portland cement-based materials. Phosphate compounds have been included in concrete mixes as set retarders. A number of cement-based binders or phosphate cements have been produced for civilengineering repair applications to take advantage of their quick setting capability. Several of the articles addressed apatite and dental applications. Finally, phosphogypsum, a main by-product of the phosphate industry, has been evaluated for application as a road base material and set retarder for Portland cement concretes.

Numerous contacts with cognizant research personnel and related industry organizations did not identify any apparent concerns or incidences of deterioration of reinforced concrete structures located in phosphate-rich locations. No special design requirements (e.g., increased cover, concrete mix proportions, or materials selection) were identified for concrete structures located in high-phosphate environments similar to that which exist for reinforced concrete structures in high sulfate or chloride environments. Finally, contacts with organizations involved with reinforced concrete structures located in high phosphate regions of Florida have not revealed any concerns or evidence of degradation of these structures due to exposure to phosphates contained in soils or ground water.

After eighteen months of curing in saturated solutions of $\mathrm{Na}_{2} \mathrm{HPO}_{4}, \mathrm{MgHPO}_{4}$ or $\mathrm{Ca}(\mathrm{OH})_{2}$ (baseline), none of the cement paste specimens showed any sign of deleterious reactions such as cracking and spalling. Length and weight change data for the specimens cured in the phosphate solutions did not exhibit any significant deviation from data obtained from baseline specimens cured in the $\mathrm{Ca}(\mathrm{OH})_{2}$ solution (i.e., after

\footnotetext{
"Relative to the "primer," a separate NUREG report has been prepared that provides a review of pertinent factors that can affect the durability of nuclear power plant reinforced concrete structures. ${ }^{3}$
} 
18-months curing the length and weight change exhibited by specimens cured in the phosphate solutions was comparable to or less than that obtained from the control solution). Results obtained for compressive strengths were uniformly high [16,000 to $20,000 \mathrm{psi}(110$ to $138 \mathrm{MPa})]$, independent of the particular curing solution. No significant difference was observed between results obtained from specimens cured in the phosphate solutions and the specimens cured in the $\mathrm{Ca}(\mathrm{OH})_{2}$ solution (baseline).

Analyses by XRD and SEM showed the presence of calcium phosphate (probably hydroxylapatite and carbonatehydroxylapatite) in the samples cured in the phosphate solutions. The results from the thermodynamic calculations were predicting that the final hydration product would be hydroxylapatite and the tests performed showed the presence of this phase. Hydroxylapatite is very stable and highly insoluble; therefore, the durability of cement or concrete where insoluble hydroxylapatite has replaced the slightly soluble calcium hydroxide should equal or increase the concrete durability.

\subsection{CONCLUSIONS}

Results of this investigation indicate that: no harmful interactions occur between phosphates and cementitious materials unless phosphates are present in the form of phosphoric acid; phosphates have been incorporated into concrete as set retarders, and phosphate cements have been used for infrastructure repair; no standards or guidelines exist pertaining to applications of reinforced concrete structures in highphosphate environments; interactions of phosphate ions and cementitious materials has not been a concern of the research community; and laboratory results indicate similar performance of specimens cured in phosphate solutions and those cured in a calcium hydroxide solution after exposure periods of up to eighteen months. 


\section{REFERENCES}

1. D. J. Naus, L. R. Dole, and C. H. Mattus, "Interim Report: Assessment of Potential Phosphate Ion-Concrete Interactions," Letter Report Attachment to Email sent to Mr. Herman L. Graves, III, U. S. Nuclear Regulatory Commission, Washington, DC, from D. J. Naus, Oak Ridge National Laboratory, Oak Ridge, Tennessee, August 26, 2005.

2. C. H. Mattus, L. R. Dole, and D. J. Naus, "Laboratory Investigation on Effects of Phosphate Ion on Concrete," Letter Report Attachment to Letter DJN/06-21 sent to Mr. Herman L. Graves, III, U. S. Nuclear Regulatory Commission, Washington, DC, from D. J. Naus, Oak Ridge National Laboratory, Oak Ridge, Tennessee, April 21, 2006.

3. D. J. Naus, "Primer on Durability of Nuclear Power Plant Reinforced Concrete Structures - A Review of Pertinent Factors," NUREG/CR-XXXX (ORNL/TM-2006/529), Oak Ridge National Laboratory, Oak Ridge, Tennessee, November 2006 (draft).

4. Outokumpu Technology Oyj, "Chemical Reaction and Equilibrium Software HSC Chemistry," HSC Version 5.11, Espoo, Finland, 2001.

5. M. J. J. M. van Kemenade and P. L. de Bruyn, "A Kinetic Study of Precipitation from Supersaturated Calcium Phosphate Solutions," Journal of Colloid and Interface Science 118(2), Academic Press, pp. 564-585, August 1987.

6. H. E. L. Madsen and G. J. Thovardarson, "Precipitation of Calcium Phosphate from Moderately Acid Solutions," J. Crystal Growth 66(2), pp. 369-376, March-April 1984.

7. J. D. Termine, R. A. Peckauskas, and A. S. Posner, "Calcium Phosphate Formation in Vitro. II. Effects of Environment on Amorphous-Crystalline Transformation," Archives of Biochemistry and Biophysics 140(2), pp. 318-325, October 1970.

8. T. Novinson, "Thermochemical Concrete Pavement Scaling Mechanism: Navy F/A- 18 Jet Aircraft Parking Apron Problems," Technical Report TR-2281-SHR, Naval Facilities Engineering Service Center, Port Hueneme, California, June 1998.

9. A. Nakamura et al., "Sorption of Chloride-ion, Sulfate-ion, and Phosphate-ion in Calcium Silicate Hydrates," Department of Inorganic Materials, Tokyo Institute of Technology, Ookayayama Meguro-ku, Tokyo, Japan.

10. F. M. Lea, The Chemistry of Cement and Concrete, Third Edition, Chemical Publishing Company, New York, New York, 1971.

11. Effects of Substances on Concrete and Guide to Protective Treatments, Portland Cement Association, Skokie, Illinois, 1997.

12. A.M. Neville and J.J. Brooks, Concrete Technology, Longman Scientific and Technical, John Wiley and Sons, New York, New York, 1990.

13. A. Kleinlogel, Influences of Concrete, Frederick Ungar Publishing Co,. New York, New York, 1941. 
14. S. Mindess and J. F. Young, Concrete, Prentiss-Hall, Inc., Englewood Cliffs, New Jersey, 1981.

15. P.K. Mehta, Concrete: Structure, Properties, and Materials, Prentiss-Hall, Inc., Englewood Cliffs, New Jersey, 1986.

16. V.S. Ramachandran and M.S. Lowry, "Effect of Phosphate-Based Compound on the Hydration of Cement and Cement Components," Special Publication 148, Fourth CANMET/ACI International Conference on Superplasticizers and Chemical Admixtures in Concrete, pp. 131-152, American Concrete Institute, Farmington Hills, Michigan, September 1994.

17. P. P. Hudec and N. K. Banahene, "Chemical Treatments and Additives for Controlling Alkali Reactivity," Cement and Concrete Composites 15 (1), pp. 21-26, Elsevier Science Publishers Ltd., 1993

18. T. Chaussandent, V. Nobel-Pujol, F. Farcas, I. Mabille, and C. Fiaud, "Effectiveness Conditions of Sodium Monoflurophoshate as a Corrosion Inhibitor for Concrete Reinforcements," Cement and Concrete Research 36(3), pp. 556-561, Elsevier Science Publishers Ltd., March 2006.

19. V. S. Famachandran, R. M. Paroli, J. J. Beaudoin, and A. H. Delgado, Handbook of Thermal Analysis of Construction Materials, William Andrew Publishing/Noyes, 2002.

20. J. E. Cassidy, "Phosphate Bonding Then and Now," American Ceramic Society Bulletin 56, pp. 640-643, 1977.

21. M. A. Shand, "Magnesia Cements," Premier Chemicals Research Center, King of Prussia, Pennsylvania.

22. Q. Yang and X. Wu, "Factors Influencing Properties of Phosphate Cement-Based Binder for Rapid Repair of Concrete," Cement and Concrete Research 29(3), pp. 389-396, Pergamon Press, 1999.

23. Z. Li, Z. Ding, and Y. Zhang, "Development of Sustainable Cementitious Materials," International Workshop on Sustainable Development and Concrete Technology," pp. 55-76, Beijing, China, May 2004.

24. A. S. Wagh et al. , "High Strength Phosphate Cement Using Industrial Byproduct Ashes," First International Conference on High Strength Concrete, Kona, Hawaii, pp. 542-555, American Society of Civil Engineers, New York, New York, July 1997.

25. W. Ma and P. W. Brown, "Hydration of Sodium Phosphate-Modified High Alumina Cement," Journal of Materials Research 9(5), p. 1291, Materials Research Society, 1996.

26. N. Abdel-Rahman and N. M. Naghoj, "Silica Phosphate in Engineering Materials," International Congress Challenges of Concrete Construction, pp. 101-107 in Concrete for Extreme Conditions, Dundee, Scotland, September 2002.

27. C. Chapman, B. Wojak, R. Peters, and P. K. Bhattacharjee, "Development Process to Manufacture Glass/Glass-Ceramic Products from Phosphogypsum," FIPR Publication No. 01153-221, Florida Institute of Phosphate Research, Bartow, Florida, April 2006. 
28. W. F. Chang, "Phosphogypsum for Secondary Road Construction," FIPR Publication \#01-033077, Florida Institute of Phosphate Research, Bartow, Florida, June 1989.

29. W. F. Chang, "Reclamation, Reconstruction, and Reuse of Phosphogypsum for Building Materials,” FIPR Publication No. 01-014-048, Florida Institute of Phosphate Research, Bartow, Florida, January 1987.

30. W. F. Chang, ”A Demonstration Project: Roller Compacted Concrete Utilizing Phosphogypsum,” FIPR Publication No. 01-068-072, Florida Institute of Phosphate Research, Bartow, Florida, December 1988.

31. J. H. Potgieter, S. S. Potgieter, R. I. McCrindle, and C. A. Strydom, "An Investigation into the Effect of Various Chemical and Physical Treatments of a South African Phosphogypsum to Render it Suitable as a Set Retarder for Cement," Cement and Concrete Research 33(8), pp. 1223-1227, Elsevier Science Ltd., August 2003.

32. L. E. Carey, H. H. K. Xu, C. G. Simon Jr.,, S. Takagi, and L. C. Chow, "Premixed Rapid-Setting Calcium Phospahte Composites for Bone Repair," Biomaterials 26(24), Elsevier Science Ltd., pp. 5002-5014, August 2005.

33. E. F. Burguera, H. H. K. Xu, S. Takagi, and L. C. Chow, "Calcium Phosphate Bone Cement with High Early Strength: Effects of Dicalcium Phosphate Dihydrate and Absorbable Fibers," Journal of Biomedical Research 75A(4), Wiley Periodicals, pp. 966-975, August 2005.

34. P. Brown, "Hydration Behavior of Calcium Phosphates is Analogous to Hydration Behavior of Calcium Silicates," Cement and Concrete Research 29, pp. 1167-1171, 1999.

35. V. T. Ngala, C. L. Page, and M. M. Page, "Corrosion Inhibitor Systems for Remedial Treatment of Reinforced Concrete. Part 2: Sodium Monofluorophosphate," Corrosion Science 45(7), Elsevier Science Ltd., pp. 1523-1537, February 2003.

36. O. Çopuroglu, A. L. A. Fraaij, and J. M. J. M. Bijen, "Effect of Sodium Monofluorophosphate Treatment on Microstructure and Frost Salt Scaling Durability of Slag Cement Paste," Cement and Concrete Research 36(8), Elsevier Science Ltd., pp. 1475-1482, August 2006.

37. N. M. Agyei, C. A. Strydom, and J. H. Potgieter, "The Removal of Phosphate Ions from Aqueous Solution by Fly Ash, Slag, Ordinary Portland Cement and Related Blends," Cement and Concrete Research 32, Elsevier Science Ltd., pp. 1889-1897, 2002.

38. T. Sugama, N. Carciello, and L. E. Kukacka, "Interface Between Zinc Phosphate-Deposited Steel Fibres and Cement Paste," Journal of Materials Science 27, Chapman and Hall, pp. 2863-2872, 1992.

39. N. M. Agyei, C. A. Strydom, and J. H. Potgieter, "An Investigation of Phosphate Ion Absorption from Aqueous Solution by Fly Ash and Slag," Cement and Concrete Research 30, Elsevier Science Ltd., pp. 823-826, 2000.

40. A. R. Brough, A. Katz, G.-K. Sun, L. J. Struble, R. J. Kirkpatrick, and J. F. Young, "Adiabatically Cured, Alkali-Activated Cement-Based Wasteforms Containing High Levels of Fly Ash - Formation of Zeolites and Al-Substituted C-S-H," Cement and Concrete Research 31, Elsevier Science Ltd., pp. 1437-1447, 2001. 
41. P. W. Brown, N. Hocker, and S. Hoyle, "Variations in Solution Chemistry During the LowTemperature Formation of Hydroxyapatitie," Journal of American Ceramic Society 74(8) pp. 1848-1854, 1991.

42. E. Oguz, A. Gürses, and N. Canpolat, "Removal of Phospahte from Watewaters," Cement and Concrete Research 33, Elsevier Science Ltd., pp. 1109-1112, 2003.

43. A. Douche-Portanguen, W. Prince, B, Malric, and G. Arliguie, "Study of the Interactions Between Sodium Monofluorophosphate and Hardened Cement Paste and Their Consequences on Concrete Transfer Properties," Cement and Concrete Research 35, Elsevier Science Ltd., pp. 1714-1723, 2005.

44. X. Feng and N. Yang, "Variations of the Anions Polymerization Degree of CaO- $-\mathrm{SiO}_{2}-\mathrm{P}_{2} \mathrm{O}_{5}-\mathrm{H}_{2} \mathrm{O}$ CBC Materials During Hydration," Cement and Concrete Research 27(3), Elsevier Science Ltd., pp. 407-413, 1997.

45. E. E. Berry, "The Structure and Composition of Some Calcium-Deficient Apatites," Journal of Inorganic Chemistry 29, Pergamon Press Ltd., pp. 317-327, 1967.

46. E. E. Berry, "The Structure and Composition of Some Calcium-Deficient Apatites - II," Journal of Inorganic Chemistry 29, Pergamon Press Ltd., pp. 1585-1590, 1967.

47. P. W. Brown, "Phase Relationships in the Ternary System CaO-P2O5-H2O at $25^{\circ} \mathrm{C}$," Journal of the American Ceramic Society 75(1), pp. 17-22, 1992.

48. Q. Yang, S. Zhang, and X. Wu, "Deicer-Scaling Resistance of Phosphate Cement-Based Binder for Rapid Repair of Concrete," Cement and Concrete Research 32, Elsevier Science Ltd., pp. 165-168, 2002.

49. F. Farcas, T. Chaussadent, C. Fiaud, and I. Mabille, "Determination of the Sodium Monofluorophosphate in a Hardened Cement Paste by Ion Chromatography," Analytica Chimica Acta 472, Elsevier Science Ltd., pp. 37-43, 2002.

50. C. Gong and N. Yang, "Effect of Phosphate on the Hydration of Alkali-Activated Red Mud-Slag Cementitious Material, Cement and Concrete Research 30, Elsevier Science Ltd., pp. 1013-1016, 2000 .

51. M. T. Fulmer, R. I. Martin, and P. W. Brown, "Formation of Calcium Deficient Hydroxyapatite at Near Physiological Temperature," Journal of Materials Science: Materials in Medicine 3, Chapman and Hall, pp. 299-305, 1992.

52. Y. Pliego-Cuervo and F. P. Glasser, "Phase Relations and Crystal Chemistry of Apatite and Silicocarnotite Solid Solutions," Cement and Concrete Research 8, Elsevier Science Ltd., pp. 519-524, 1978.

53. J-W. Jang, M. G. Hagen, G. M. Engstrom, and I. Iwasaki, " $\mathrm{Cl}^{-}, \mathrm{SO}_{4}{ }^{2-}$, and $\mathrm{PO}_{4}{ }^{3-}$ Distribution in Concrete Slabs Ponded by Corrosion-Inhibitor-Added Deicing Salts," Advanced Cement Based Materials 8, Elsevier Science Ltd., pp. 101-107, 1998. 
54. L. Shiqun, H. Jiashan, L. Biao, Z. Guohui, C. Wei, W. Qi, and Z. Ning, "Fundamental Study of Aluminophosphate Cement," Cement and Concrete Research 29, Elsevier Science Ltd., pp. 1549$1554,1999$.

55. M. Singh, "Effect of Phosphatic and Fluoride Impurities of Phosphogypsum on the Properties of Selenite Plaster," Cement and Concrete Research 33, Elsevier Science Ltd., pp. 1363-1369, 2003.

56. A. Guerrero, S. Hérnandez, and S. Goñi, "Durability of Cement-Based Materials in Simulated Radioactive Liquid Waste: Effect of Phosphate, Sulphate, and Chloride Ions," Journal of Materials Research 13(8), Materials Research Society, pp. 2151-2160, 1997.

57. Y. Doi, Y. Shimizu, Y. Moriwaki, M. Aga, H. Iwanaga, T. Shibutani, Yamamoto, and Y. Iwayama, "Development of a New Calcium Phosphate Cement that Contains Sodium Calcium Phosphate," Biomaterials 22(8), pp. 847-854, April 2001.

58. Z. Ding and Z. Li, "High-Early-Strength Magnesium Phosphate Cement with Fly Ash," ACI Materials Journal 102(6), American Concrete Institute, Farmington Hills, Michigan, NovemberDecember 2005.

59. A. S. Wagh, S-Y. Jeong, and D. Singh, "High Strength Phosphate Cement Using Industrial Byproduct Ashes," Proceedings of First International Conference on High Strength Concrete, Kona, Hawaii, American Society of Civil Engineers, New York, New York, pp. 542-550, 1997.

60. L. C. Chow, "Development of Self-Setting Calcium Phosphate Cements, Journal of the Ceramic Society of Japan 89(1154), pp. 954-964, 1991.

61. "Standard Practice for Mechanical Mixing of Hydraulic Cement Pastes and Mortars of Plastic Consistency," ASTM 305-06, Annual Book of ASTM Standards, American Society for Testing and Materials, West Conshohocken, Pennsylvania, 2006.

62. "Standard Test Method for Length Change of Hardened Cement Paste, Mortar, and Concrete," ASTM C157-99, Annual Book of ASTM Standards, American Society for Testing and Materials, West Conshohocken, Pennsylvania, 2006.

63. "Standard Test Method for Compressive Strength of Hydraulic Cement Mortars (Using 2-in, Cubes)," ASTM 109/109M-05, Annual Book of ASTM Standards, American Society for Testing and Materials, West Conshohocken, Pennsylvania, 2006.

64. G. Le Saout, E. Lécollier, A. Rivereau, and H. Zanni, "Chemical Structure of Cement Aged at Normal and Elevated Temperatures and Pressusres. Part I. Class G Oilwell Cement" Cement and concrete research 36(1), pp. 71-78, January 2006.

65. L. J. Struble, "The Effect of Water on Maleic Acid and Salicylic Acid Extractions," Cement and Concrete Research 15(4), pp. 631-636, Elsevier Science Ltd., July 1985. 


\section{APPENDIX A}

\section{COMMENTS ON PHOSPHATE ATTACK ON CONCRETE}

The NRC Staff has set limits on the concentrations of chloride and sulfate ions in ground water solutions adjacent to concrete structures in nuclear power plants. When ground waters exceed these concentrations at a power plant seeking license renewal, special inspections of the concrete are needed. The reasons for the limits on ion concentrations are not well explained, but it appears that the limit on chloride concentration has to do with the corrosion of reinforcing bars in the concrete and the limit on sulfate ion has to do with decrepitation of the concrete. Sulfate solutions are known to decrepitate concrete because the sulfate can react with the binding agent in concrete, calcium hydroxide or $\mathrm{Ca}(\mathrm{OH})_{2}$, to convert it to calcium sulfate, either $\mathrm{CaSO}_{4} \bullet 1 / 2 \mathrm{H}_{2} \mathrm{O}$ or $\mathrm{CaSO}_{4} \bullet 2 \mathrm{H}_{2} \mathrm{O}$, which is more voluminous and nonbonding.

The basis for the limit on sulfate ion can be understood by considering the point at which calcium hydroxide and calcium sulfate are in equilibrium:

$$
2 \mathrm{H}_{2} \mathrm{O}+\mathrm{Ca}(\mathrm{OH})_{2}(\mathrm{~s})+\mathrm{SO}_{4}^{2-} \leftrightarrow \mathrm{CaSO}_{4} \cdot 2 \mathrm{H}_{2} \mathrm{O}(\mathrm{s})+2 \mathrm{OH}^{-}
$$

The equilibrium constant ${ }^{1}$ for this reaction is:

$$
\mathrm{K}=0.108=\frac{\left[\mathrm{OH}^{-}\right]^{2}}{\left[\mathrm{SO}_{4}^{2-}\right]}
$$

At concentrations of sulfate ion lower than specified by this equilibrium constant, no calcium sulfate will form. At higher sulfate ion concentrations, the calcium hydroxide will be converted totally into calcium sulfate. The limiting concentration of sulfate ion is dependent on the hydroxide concentration of the solution as indicated by the equilibrium expression.

The hydroxide ion concentration of interest for this equilibrium is not that of the bulk solution. Rather, it is the hydroxide concentration of solutions in the pore structures of concrete in equilibrium with calcium hydroxide. This hydroxide concentration can be calculated from:

$$
\begin{gathered}
\mathrm{Ca}(\mathrm{OH})_{2}(\mathrm{~s}) \leftrightarrow \mathrm{Ca}^{2+}+2 \mathrm{OH}^{-} \\
\mathrm{K}_{\mathrm{sp}}=4.65 \times 10^{-6}=\left[\mathrm{Ca}^{2+}\right]\left[\mathrm{OH}^{-}\right]^{2} \\
\mathrm{Ca}^{2+}+\mathrm{OH}^{-} \leftrightarrow \mathrm{CaOH}^{+} \\
\mathrm{K}_{\mathrm{cl}}=21.2=\frac{\left[\mathrm{CaOH}^{+}\right]}{\left[\mathrm{Ca}^{2+}\right]\left[\mathrm{OH}^{-}\right]}
\end{gathered}
$$

\footnotetext{
${ }^{1}$ Except as noted, equilibrium constants used here are derived from free energy data assembled in A. J. Bard, R. Parsons, and J. Jones, "Standard Potentials in Aqueous Solution," Marcel Dekker, New York, New York, 1985.
} 


$$
\begin{gathered}
\mathrm{Ca}^{2+}+2 \mathrm{OH}^{-} \leftrightarrow \mathrm{Ca}(\mathrm{OH})_{2}(\mathrm{aq}) \\
\mathrm{K}_{\mathrm{c} 2}=1.006=\frac{\left[\mathrm{Ca}\left(\mathrm{OH}_{2}\right)\right]}{\left[\mathrm{Ca}^{2+}\right]\left[\mathrm{OH}^{-}\right]^{2}}
\end{gathered}
$$

and the charge balance equation:

$$
2\left[\mathrm{Ca}^{2+}\right]+\left[\mathrm{CaOH}^{+}\right]+\left[\mathrm{H}^{+}\right]=\left[\mathrm{OH}^{-}\right]
$$

or

$$
2 \mathrm{~K}_{\mathrm{sp}}+\left(\mathrm{K}_{\mathrm{sp}} \mathrm{K}_{\mathrm{cl}}+\mathrm{K}_{\mathrm{w}}\right)\left[\mathrm{OH}^{-}\right]=\left[\mathrm{OH}^{-}\right]^{3}
$$

where $K_{\mathrm{w}}$ is the ionization constant of water $\sim 1 \times 10^{-14}$. Solution of this expression yields:

$$
\left[\mathrm{OH}^{-}\right]=0.0226 \mathrm{~mole} / \mathrm{kg} \mathrm{H} \mathrm{H}_{2} \mathrm{O}
$$

which corresponds to a local $\mathrm{pH}=12.35$. At this high $\mathrm{pH}$, sulfate will be present largely as sulfate ion and the bisulfate ion can be neglected. Consequently, the coexistence of calcium hydroxide and calcium sulfate occurs (at $298 \mathrm{~K}$ ) at:

$$
\left[\mathrm{SO}_{4}^{2-}\right]=4.7 \times 10^{-3} \text { mole } / \mathrm{kg} \mathrm{H}_{2} \mathrm{O}=452 \mathrm{ppmw} .
$$

This is consistent with the limit the Staff has prescribed. A somewhat higher limit can be tolerated because of ion association between calcium ion and the sulfate ion:

$$
\mathrm{Ca}^{2+}+\mathrm{SO}_{4}^{2-} \leftrightarrow \mathrm{CaSO}_{4}(\mathrm{aq}) \quad \mathrm{K}_{\mathrm{eq}}=1
$$

The analysis above appears to be consistent with Staff determinations. The question to address now is whether limits need to be placed on phosphate concentrations of ground waters for the same reasons that limits are placed on sulfate ion. There are a variety of calcium phosphates that can be of interest, but the most common and bothersome of the phosphates is apatite (sometimes called hydroxyapatite),

$\mathrm{Ca}_{5}\left(\mathrm{PO}_{4}\right)_{3} \mathrm{OH}$ or sometimes $\mathrm{Ca}_{10}\left(\mathrm{PO}_{4}\right)_{6}(\mathrm{OH})_{2}$. Apatite will not be bonding and is more voluminous than calcium hydroxide. If calcium hydroxide in the pore structure of concrete were converted into apatite, concrete decrepitation might be possible.

To determine the conditions of apatite stability in the pore structure of concrete, an analysis entirely similar to that above for calcium sulfate formation is carried out. The phase boundary is determined by the equilibrium:

$$
5 \mathrm{Ca}(\mathrm{OH})_{2}(\mathrm{~s})+3 \mathrm{PO}_{4}^{3-} \leftrightarrow \mathrm{Ca}_{5}\left(\mathrm{PO}_{4}\right)_{3} \mathrm{OH}(\mathrm{s})+9 \mathrm{OH}^{-}
$$

The equilibrium constant for this equilibrium is:

$$
\mathrm{K}=3.31 \times 10^{36}=\frac{\left[\mathrm{OH}^{-}\right]^{9}}{\left[\mathrm{PO}_{4}^{3-}\right]^{3}} .
$$


Again, the hydroxide ion concentration of interest here is that established in the pore waters of the concrete by calcium hydroxide as described above. The phosphate ion concentration in the equilibrium expression needs to be related to the total phosphate concentration of the water and this is complicated by the equilibria:

$$
\begin{gathered}
\mathrm{PO}_{4}^{3-}+\mathrm{H}_{2} \mathrm{O} \leftrightarrow \mathrm{HPO}_{4}^{2-}+\mathrm{OH}^{-} \\
\mathrm{K}_{\mathrm{p} 1}=0.0218=\frac{\left[\mathrm{HPO}_{4}^{2-}\right]\left[\mathrm{OH}^{-}\right]}{\left[\mathrm{PO}_{4}^{3-}\right]} \\
\mathrm{HPO}_{4}^{2-}+\mathrm{H}_{2} \mathrm{O} \leftrightarrow \mathrm{H}_{2} \mathrm{PO}_{4}^{-}+\mathrm{OH}^{-} \\
\mathrm{K}_{\mathrm{p} 2}=1.58 \times 10^{-7}=\frac{\left[\mathrm{H}_{2} \mathrm{PO}_{4}^{-}\right]\left[\mathrm{OH}^{-}\right]}{\left[\mathrm{HPO}_{4}^{2-}\right]} .
\end{gathered}
$$

The total phosphate content is then given by:

$$
\begin{gathered}
\mathrm{P}_{\mathrm{t}}=\mathrm{PO}_{4}^{3-}+\mathrm{HPO}_{4}^{2-}+\mathrm{H}_{2} \mathrm{PO}_{4}^{-} \\
=\left[\mathrm{PO}_{4}^{3-}\right]\left(1+\frac{\mathrm{K}_{\mathrm{p} 1}}{\left[\mathrm{OH}^{-}\right]}+\frac{\mathrm{K}_{\mathrm{pl}} \mathrm{K}_{\mathrm{p} 2}}{\left[\mathrm{OH}^{-}\right]^{2}}\right) .
\end{gathered}
$$

For the hydroxide ion concentrations of interest,

$$
\left[\mathrm{PO}_{4}^{3-}\right]=0.509 \mathrm{P}_{\mathrm{t}}
$$

There are ion associates between calcium ion and the various phosphate species such as:

$$
\begin{gathered}
\mathrm{Ca}^{2+}+\mathrm{HPO}_{4}^{2-} \leftrightarrow \mathrm{CaHPO}_{4}(\mathrm{aq}) \quad \mathrm{K}=1.6 \\
3 \mathrm{Ca}^{2+}+2 \mathrm{PO}_{4}^{3-} \leftrightarrow \mathrm{Ca}_{3}\left(\mathrm{PO}_{4}\right)_{2}(\mathrm{aq}) \quad \mathrm{K}=2.2
\end{gathered}
$$

These associates will raise the total phosphate concentration needed to form apatite above that calculated here. Neglecting these, the total phosphate concentration for apatite formation is found to be:

$$
\mathrm{P}_{\mathrm{t}}=1.52 \times 10^{-17} \text { moles } / \mathrm{kg} \mathrm{H} \mathrm{H}_{2} \mathrm{O} \text {. }
$$

This is quite a low phosphate concentration, but the result is not surprising since apatite is a very stable mineral. It is, after all, the mineral that makes up much of teeth. Though the real phosphate concentration necessary to cause apatite formation in the pore structure may be higher than calculated here, this result is evidence that a modest phosphate ion concentration in ambient water is worthy of consideration in the context of concrete aging.

The Staff has not found citations in the literature dealing with the need to have caution about the phosphate concentrations of ground water around concrete structures of nuclear power plants. Indeed, it 
will not be common for ground water to be particularly rich in phosphate except in areas with peculiar geology or near farm lands where phosphate fertilizers have been used extensively in the past.

Nevertheless, the exploratory analysis above certainly suggests some caution is needed and ought to be enough to institute a more definitive investigation. Such a definitive investigation would have to account for the rich chemistry of phosphate species in the environment of concrete pores. 


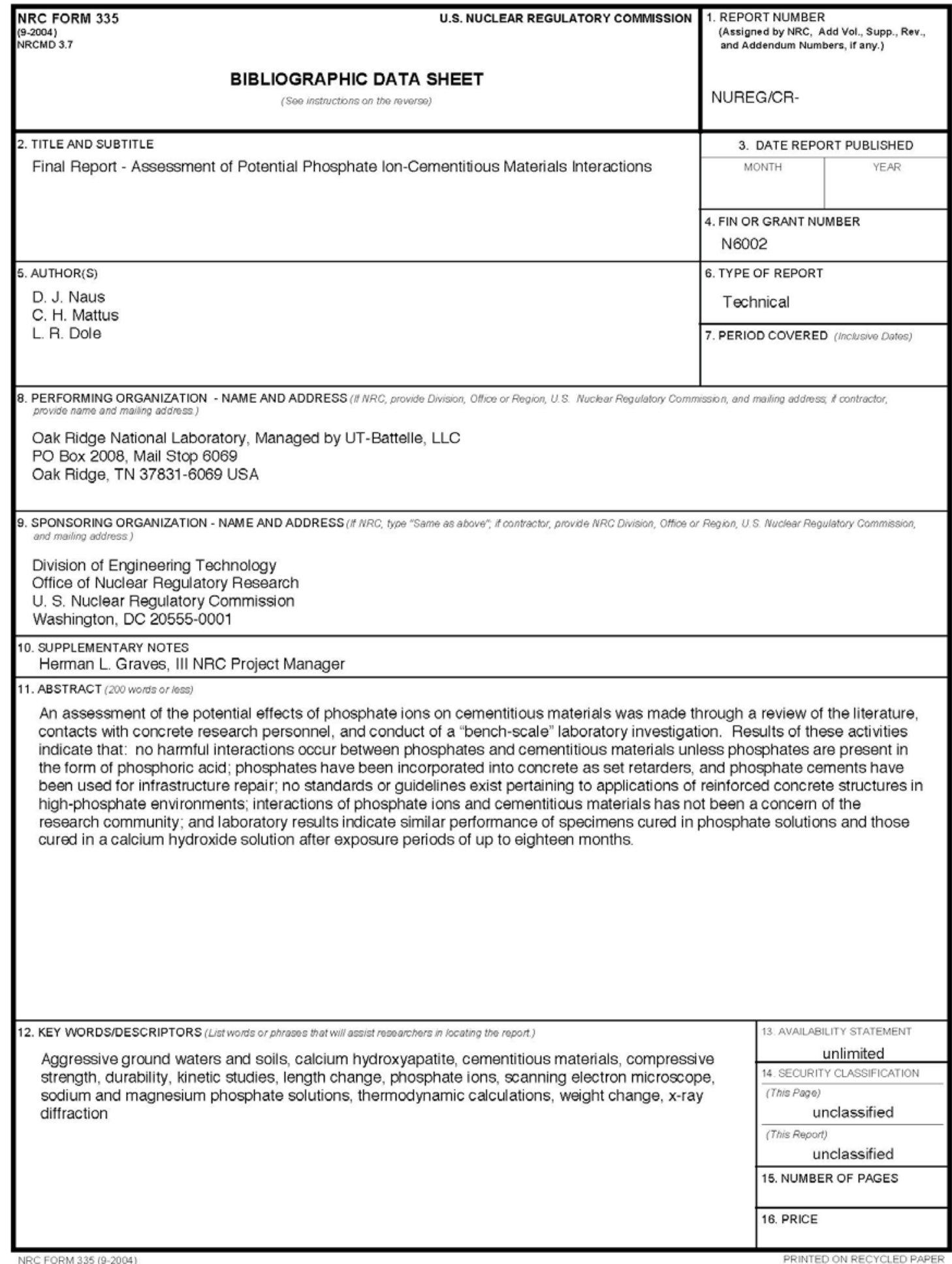


